\title{
ESTUDO DO TESTE DE LIXIVIAÇÃO DE POTÁSSIO PARA AVALIAÇÃO DA QUALIDADE FISIOLÓGICA DE SEMENTES DE SOJA
}

\author{
CECI CASTILHO CUSTÕDIO \\ Engenheira Agrônoma
}

Orientador: Prof. Dr. JÚLIO MARCOS FILHO

\begin{abstract}
Dissertação apresentada à Escola Superior de Agricultura "Luiz de Queiroz", da Universidade de São Paulo, para obtenção do título de Mestre em Agronomia - Área de Concentração: Fitotecnia.
\end{abstract}

PIRACICABA

ESTADO DE SÃO PAULO - BRASIL

MAIO - 1995 
CATALOBSOA HA FUELIEARE

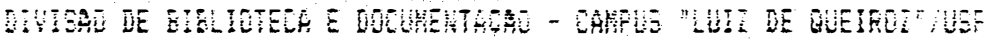

Custotio. Ceti cestihe

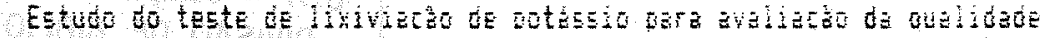

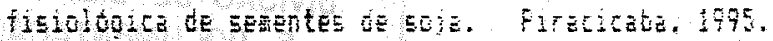
1150.

Diselhetre: - ESFiE

Eibliogritio.

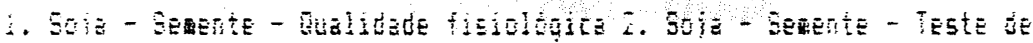

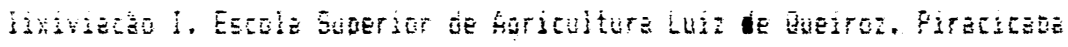




\title{
ESTUDO DO TESTE DE LIXIVIAÇÃO DE POTÁSSIO PARA AVALIAÇÃO DA QUALIDADE RTŞYLÓGICA DE SEMENTES DE SOJA
}

\author{
CECI CASTILHO CUSTÓdIO
}

Aprovada em: 30.06 .95

Comissão Julgadora:

Prof. Dr. JÚLIO MARCOS FILHO

ESALQ/USP

Prof ${ }^{a}$. Dr ${ }^{a}$. ANA DIONÍSIA DA LUZ COELHO NOVEMBRE

ESALQ/USP

Prof. Dr. ROBERVAL DAITON VIEIRA

FCAV/UNESP

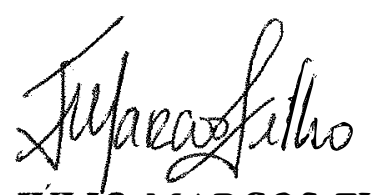

Prof. Dr. JÚLIO MARCOS FILHO

Orientador 
A sabedoria inspira vida a seus filhos, e toma debaixo da sua proteção aos que a buscam, e irá diante deles no caminho da justiça; e o que a ama, ama a vida; e os que velarem para a achar, gozaräo do seu prazer.

Aqueles que a possuirem, terão a vida por herança; e onde ela entrw, Deus abençoará tudo.

Ecl 4: 12-14.

Aos meus pais Miguel e Dirce

Aos meus tios Dorival e Eunice

Ao meu irmão Helder e

Ao meu amigo Rodrigo

pelo estímulo numo ao aperfeiçoamento, a todos dedico. 


\section{AGRADECIMENTOS}

Ao Prof. Dr. Júlio Marcos Filho pela orientação segura e dedicada.

Aos Professores Francisco Ferraz de Toledo, Silvio Moure Cícero e Walter Rodrigues da Silva pelos ensinamentos e estímulo.

Às Engenheiras Agrônomas Ana Dionísia L.C. Novembre e Helena M.C.P. Chamma pelo apoio e amizade.

À Prof ${ }^{a}$ Maria Cristina Stolf Nogueira pela colaboração no planejamento da análise estatística.

Ao Prof. Quirino A.C. Carmello e Prof. Arnaldo Antônio Rodella pela atenção e valiosas contribuições.

À Engenheira Agrônoma Maria Heloisa Duarte Moraes pela valiosa contribuição através do Laboratório de Fitopatologia nos testes de sanidade com as sementes.

Aos funcionários do Departamento de Agricultura, em especial a Ilze Helena C.D. Neves e Hodair Banzatto pelos serviços prestados e pela paciência com que nos atendem.

Aos colegas de pós-graduação pela amizade, carinho e incentivos, em especial a Denise C.F. dos Santos Dias, Gisele Herbst Vazquez, Édila V. Rezende Von Pinho, Cláudio Cavariani, Maria Cristina M. Spínola, Marco Antonio de Souza, Ana Carmen V. Vidal, Monalisa A. Diniz da Silva, Raimundo Velasco Nuño, Denise A.C. Bília, Cláudia Rossetto e Cibele Chalita Martins. 
À Empresa Comércio e Indústria de Sementes Brejeiro através do Eng. Agr. Celso Okano e ao IAPAR na pessoa do Eng. Agr. Alberto S.R. Barros pela doação das sementes.

À Fundação de Amparo à Pesquisa do Estado de São Paulo FAPESP - pelo suporte financeiro para a realização do projeto.

À Coordenadoria de Aperfeiçoamento de Pessoal de Nivel Superior CAPES - pela bolsa de estudos concedida.

À Universidade do Oeste Paulista - UNOESTE, pelo apoio. 


\section{SUMÁRIO}

Página

AGRADECIMENTOS

RESUMO

X

SUMMARY

xii

1. INTRODUÇÃO

2. REVISÃO DE LITERATURA . . . . . . . . . . . . . . . 3

2.1. Deterioração e vigor das sementes . . . . . . . . . . . . 3

2.2. Membranas celulares e vigor . . . . . . . . . . . . . . . 6

2.3. Testes para avaliação rápida da qualidade fisiológica . . . . . . 13

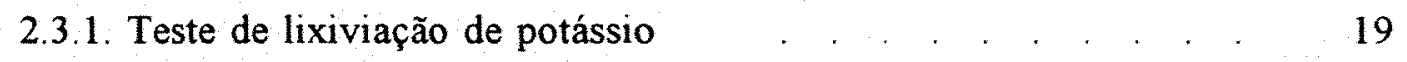

3. MATERIAL E MÉTODOS . . . . . . . . . . . . . . . . 24

3.1. Experimento I . . . . . . . . . . . . . . . . . 24

3.1.1 Recepção das amostras . . . . . . . . . . . . . 25

3.1.2. Determinação do grau de umidade . . . . . . . . . . 25

3.1.3. Teste de germinação . . . . . . . . . . . . . . . 25

3.1.4. Envelhecimento acelerado . . . . . . . . . . . 26

3.1.5. Condutividade elétrica

3.1.6. Emergência das plântulas em campo ‘ . . . . . . . . . 27

3.2. Experimento II _ c c c c c c c c c c c c c c c c c . 28

3.3. Experimento III . c c c c c c c c c c c . c c . c c 30

3.3.1. Determinações complementares . . . . . . . . . . . 31

3.3.1.1. Peso de 1000 sementes . . . . . . . . . . 31

3.3.1.2. Análise da composição química das sementes . . . . . 31 
3:3.1.4. Dados de temperatura e umidade relativa do ambiente de armazenamento

3.3.2. Teste de lixiviação de potássio

3.3.3. Outras avaliações

\$3.3.4. Primeira contagem da germinação

3.3.5. Procedimento estatístico

4. RESULTADOS E DISCUSSÃO

4.1. Experimento I

4.1.1. Cultivar BR 38

4.1.2. Cultivar BR 36

4.1.3. Cultivar IAC 15

4.1.4. Cultivar IAS 5

4.1.5. Considerações gerais

4.2. Experimento II

4.2.1. Estudo das curvas de calibração do fotômetro de chama

4.2.2. Considerações gerais

4.3.1. Determinações complementares _. . . . . . . . . . . . . . . . 52

4.3.1.1. Peso de 1000 sementes . . . . . . . . . . . . . . 52

4.3.1.2. Análise da composição química das sementes . . . . . . . 54

4.3.1.3. Teste de sanidade . . . . . . . . . . . . . . . 55

4.31.4. Dados de temperatura e umidade relativa do ambiente de armazenamento

4.3.2. Teste de lixiviação de potássio $\quad$. . . . . . . . . . . . . . . 58

4.3.2.1. Cultivar BR 38 . . . . . . . . . . . . . . . . 58

4.3.2.1. Testes de lixiviação de potássio realizados a $25^{\circ} \mathrm{C} \quad$. . . . $\quad 59$

4.3.2.1.2. Testes de lixiviação de potássio realizados a $30^{\circ} \mathrm{C} \quad$. . . $\quad 63$

4.3.2.1.3. Considerações gerais _. . . . . . . . . . . . . . . 67 
4.3.2.2. Cultivar IAC 15 . . . . . . . . . . . . . . . . . 68

4.3.2.2.1. Testes de lixiviação de potássio realizados a $25^{\circ} \mathrm{C}$. . . 70

4.3.2.2.2. Testes de lixiviação de potássio realizados a $30^{\circ} \mathrm{C} \quad$. . . $\quad 75$

4.3.2.2.3. Considerações gerais . . . . . . . . . . . . . 79

4.3.3. Outros testes para avaliação da qualidade físiológica . . . . $\quad 80$

4.3.3.1. Cultivar BR $38 \ldots \ldots$

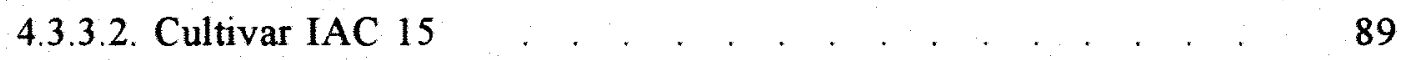

4.3.4. Considerações gerais . . . . . . . . . . . . . . . . . . 97

5. CONCLUSÃO

REFERÊNCIAS BIBLIOGRÁFICAS _ . . . . . . . . . . . . . . . . . . 99

ANEXO . . . . . . . . . . . . . . . . . . . . . . . 114 


\title{
ESTUdO DO TESTE DE LIXIVIAÇÃO DE POTÁSSIO PARA AVALIAÇÃO DA QUALIDADE FISIOLÓGICA DE SEMENTES DE SOJA
}

\author{
Autor: CECI CASTILHO CUSTÓDIO \\ Orientador: Prof. Dr. JÚLIo MARCOS FILHo
}

RESUMO

Diante da necessidade de respostas complementares às fornecidas pelo teste de germinação ou que apresentem a possibilidade de resultados confiáveis em um período de tempo relativamente curto, agilizando as decisões, foi conduzido este trabalho no Laboratório de Análise de Sementes e no Campo Experimental da Escola Superior de Agricultura "Luiz de Queiroz", da Universidade de São Paulo, com o objetivo de obter informações que possam contribuir para a obtenção de novos conhecimentos sobre o teste de lixiviação de potássio, para avaliação do vigor de sementes de soja (Glycine max (L.) Merrill).

Para tanto, utilizaram-se dois cultivares (BR 38 e IAC 15), cada qual representado por cinco lotes. Foram estudadas duas quantidades de água destilada ( 75 e 100 ml) e três períodos de embebição das sementes (30,60 e 90 minutos), compondo, assim, seis tratamentos formados pela combinação entre a quantidade de água e os períodos de 
embebição. Avaliaram-se, ainda, duas temperaturas para embebição $\left(25\right.$ e $\left.30^{\circ} \mathrm{C}\right) . \mathrm{A}$ eficiência da metodologia foi estimada comparativamente às informações fornecidas por outros testes, ou sejam, os testes de germinação, envelhecimento acelerado, condutividade elétrica e emergência das plântulas em campo. Os testes foram repetidos em três épocas de avaliação, com intervalos aproximadamente bimestrais.

A análise dos dados e a interpretação dos resultados permitiram concluir que o teste de lixiviação de potássio pode se constituir em uma opção eficiente para a avaliação da qualidade fisiológica de sementes de soja, apresentando a sensibilidade necessária para a identificação de diferenças de vigor. Dentre as variações disponíveis na metodologia, a embebição das sementes em $75 \mathrm{ml}$ ou $100 \mathrm{ml}$ de água destilada, durante 30 minutos a $30^{\circ} \mathrm{C}$, proporciona respostas mais rápidas e leituras mais precisas no fotômetro de chama. 


\author{
Author: CECI CASTILHO CUSTÓdIO \\ Adviser: Prof. Dr. JULLO MARCOS FILHO
}

SUMMARY

In view of the need for complementary answers to those provided by germination tests or tests feasible to present reliable results within a relatively short period, in order to speed decisions, this work was conducted in the Seed Analysis Laboratory and in the Experimental Field of the Department of Agriculture/Escola Superior de Agricultura "Luiz de Queiroz", University of São Paulo, Brazil, with the aim of gathering information likely to improve knowledge on potassium leakage tests for the evaluation of soybean (Glycine max (L.) Merrill) seed vigor.

Two cultivars (BR 38 and IAC 15) were used, each one represented by five lots. Two quantities of distilled water $(75$ and $100 \mathrm{ml})$ and three periods of seed imbibition $(30,60$, and 90 minutes) were studied, thus amounting six treatments comprising the combination of water quantity and imbibition periods. In addition, two imbibition temperatures $\left(25\right.$ and $\left.30^{\circ} \mathrm{C}\right)$ were compared. The methodology efficiency was evaluated in comparison to information with those of other tests considered suitable for determining the physiological quality of soybean seeds (germination tests, accelerated 
aging, electrical conductivity, and field seedling emergence). The tests were replicated throughout three evaluation periods with approximately bimonthly intervals.

The data analysis and interpretation of results revealed that potassium leakage may be an efficient option for the evaluation of the physiological quality of soybean seeds with sensitivity enough to identify vigor differences. Among the variations available in the methodology, seed imbibition in $75 \mathrm{ml}$ or $100 \mathrm{ml}$ of distilled water for 30 minutes at $30^{\circ} \mathrm{C}$ provides more rapid responses and more accurate flame photometer readings. 


\section{INTRODUÇÃO}

As sementes de soja são reconhecidamente problemáticas em termos de qualidade fisiológica. Isto se deve basicamente, à sua composição química e grande sensibilidade que apresentam a fatores climáticos, fazendo que certas áreas aptas à produção de grãos não se prestem à produção de sementes de boa qualidade. Além disto, são muito vulneráveis às danificações mecânicas devido à localização do embrião; apresentam problemas de ordem sanitária e tendência a rápida deterioração.

Assim, é interessante que as entidades produtoras de sementes disponham de recursos técnicos para a avaliação rápida e eficiente da qualidade física, fisiológica e sanitária, possibilitando o aproveitamento dos melhores lotes, por ocasião da recepção, durante o processamento ou armazenamento, com diminuição acentuada da probabilidade de prejuízos econômicos. Esta iniciativa também permite a racionalização do manejo dos lotes de sementes e a utilização mais eficiente da infraestrutura existente.

A avaliação da qualidade fisiológica se dá basicamente através do teste de germinação; porém, devido às limitações desse teste, principalmente no que se refere à diferenciação de lotes e à relativa demora de obtenção dos resultados, os 
pesquisadores têm, nas últimas décadas procurado desenvolver testes de vigor: Nestes, buscam-se respostas complementares às fornecidas pelo teste de germinação ou que apresentem a possibilidade de resultados confiáveis em um período de tempo relativamente curto, agilizando as decisões.

Assim, através do exame da literatura, observa-se que, atualmente, os testes rápidos mais desenvolvidos são o teste de tetrazólio e aqueles baseados na permeabilidade das membranas, destacando-se o teste de condutividade elétrica. $O$ teste de lixiviação de potássio, apesar de pouco estudado, tem se revelado promissor, podendo apresentar respostas similares à condutividade elétrica, em prazo de tempo mais curto.

Desta forma, o objetivo deste trabalho é obter informações que possam contribuir para a obtenção de novos conhecimentos sobre o teste de lixiviação de potássio e permitir a obtenção mais rápida de resultados de pronta utilização pela indústria de sementes. 


\section{REVISÃO DE LITERATURA}

\subsection{Deterioração e vigor das sementes}

As sementes, como bem documenta a literatura, atingem o máximo potencial fisiológico por ocasião da maturidade. Daí em diante, passam por certas mudanças degenerativas, que reduzem a capacidade de sobreviver e levam a perda de vigor e germinação. Essas alterações em seu desempenho caracterizam o processo de deterioração (ANDERSON, 1973).

Vigor de sementes compreende aquelas propriedades que determinam o potencial para uma emergência rápida e uniforme e para o desenvolvimento de plântulas normais sob uma ampla faixa de condições ambientais (CHING, 1973; ABDUL-BAKI, 1980; AOSA, 1983).

No entanto CHING (1973) alertou que, enquanto o padrão de germinação e crescimento é programado pela carga genética da espécie e cultivar, a expressão, no entanto, é frequentemente modificada pelas condições ambientais sob as quais as sementes são produzidas, colhidas, processadas, tratadas, armazenadas e semeadas 
Portanto, o vigor de um lote de sementes deriva da interação de todos os parâmetros envolvidos e a taxa de deterioração depende de três fatores principais: temperatura, grau de umidade das sementes e, em menor extensão, da pressão de oxigênio do ambiente de armazenamento (ROBERTS, 1981; MATTHEWS, 1985).

O processo de deterioração apresenta características específicas, dependendo do nível em que o processo é examinado (MATTHEWS, 1985). Quando considerado no plano de uma semente, evidencia-se, em primeiro lugar, pela redução na velocidade de germinação, porém como as características afetadas tanto em lotes como em sementes individuais são praticamente as mesmas, fica dificil fazer-se uma clara distinção entre um nível e outro.

CHAUHAN (1985), utilizando sementes de soja e de cevada, constatou que a deterioração de uma semente inicia-se nas extremidades do eixo embrionário (plúmula e radícula) e caminha em direção à porção mediana, tendo ainda verificado que os tecidos de reserva (endospermático e cotiledonar) são os mais resistentes à deterioração. ANDERSON (1973) já havia feito referência ao fato, mostrando que os resultados dos estudos dependiam da semente ou parte da semente que era considerada, do processo que era mensurado e das condições as quais a semente era submetida.

Segundo CHING (1973) os principais sítios de envelhecimento a nível celular são os mitocôndrios, os ribossomos e as membranas. Para DELOUCHE \& BASKIN (1973) constatam-se principalmente danos às membranas. POWELL (1986) considerou que reduções na atividade enzimática e respiratória e na síntese de macromoléculas são decorrência da deterioração inicial das membranas. ROBERTS (1973) relatou que, além de 
cristas dilatadas, são também sinais do envelhecimento da semente, mitocôndrios inchados e com matriz densa e coagulada Como o mitocôndrio é o centro da respiração e a ele é atribuida, também, a capacidade de sintetizar proteínas, tem papel relevante no declínio da atividade respiratória inicial de plântulas provindas de sementes senescentes (PARRISH \& LEOPOLD, 1978; ABDUL-BAKI, 1980) bem como na restauração de danos à membrana (CARVALHO, 1994).

Segundo BERJAK \& VILLIERS (1972a; 1972b) os plastídeos, corpúsculos de Golgi, retículo endoplasmático e ribossomos apresentam também modificações, podendo se mostrar ausentes ou degenerados no início da germinação de sementes envelhecidas mas, com o decorrer do processo, podem se regenerar completamente. É possível, então, que o maior tempo necessário para a germinação de sementes de baixo vigor seja conseqüência da desorganização dos processos metabólicos e da necessidade de operação de mecanismos de reparo dos danos às organelas (CARVALHO, 1994). Para ABDUL-BAKI \& BAKER (1973), organelas em sementes estão continuamente mudando, em resposta a mudança no ambiente interno das células; estas mudanças em organelas associadas com deterioração compreendem apenas uma pequena parte do total de alterações que ocorrem no início do período de quiescência.

Há evidências consideráveis para mostrar que danificações cromossômicas e mutações genéticas ocorrem durante 0 armazenamento de sementes (ROBERTS, 1973; ROBERTS, 1981; MATTHEWS, 1985). Desde que a maioria das mutações são recessivas, ao contrário de produzir plântulas anormais diretamente, muitas anormalidades não são manifestadas até gerações subseqüentes, quando ocorrem as 
segregações. Danos visíveis aos cromossomos começam a ocorrer assim que se inicia a queda na viabilidade das sementes; isto tem efeitos consideráveis no manejo de bancos de germoplasmas (MATTHEWS, 1985).

Por efeito do envelhecimento, ocorrem mudanças na atividade e/ou nas características de substâncias que compõem a semente, principalmente daquelas que desempenham algum papel no processo de germinação. Estudos de ROBERTS (1981) demonstram que as enzimas desidrogenases tornam-se menos ativas e há declínio na habilidade para incorporar leucina, uracila e fosfato aos metabólitos. Para ANDERSON (1973) o efeito da deterioração na síntese de polissacarídeos e proteínas é mais pronunciado que o efeito sobre a respiração, porém ocorre redução na absorção de $\mathrm{O}_{2}$ como também foi observado por GILL \& DELOUCHE (1973). Outras mudanças ocorrem, como o declínio na síntese de lipídios, declínio nos teores de lipídios e fosfolipídios estruturais e incremento nos ácidos graxos livres, declínio de açúcares solúveis, redutores e não redutores, declínio de proteínas, aminoácidos e fosfato inorgânico e incremento na lixiviação de substâncias orgânicas e inorgânicas (ANDERSON, 1973).

\subsection{Membranas celulares e vigor}

As membranas são constituídas por proteinas, lipídios e carboidratos. As proteínas representam o principal componente, desempenhando papel importante, não só na estruturação mecânica da membrana, mas também como transportadoras ou canais de transporte. Além disso, podem estar relacionadas com propriedades reguladoras ou de 
reconhecimento. Estão, também, presentes na membrana plasmática numerosas enzimas, antígenos e diversos tipos de moléculas receptoras como os fitocromos (De ROBERTIS \& De ROBERTIS Jr., 1981.

As membranas celulares seriam constituídas por uma camada dupla de moléculas de lipídios, às quais se associariam, interna e externamente, moléculas de proteínas (BRANTON, 1969; BEWLEY, 1986). Os principais constituintes da camada dupla de lipídios são os chamados lipídos polares, dos quais os mais abundantes são os fosfolipídios. Esses lipídios são chamados polares por se apresentarem como moléculas cujas extremidades demonstram comportamentos opostos com relação à afinidade por água. Em uma extremidade, está situado o grupo principal que é hidrofilico; na outra, estão situados ácidos graxos de cadeias longas, que se constituem no grupo hidrofóbico.

Segundo BEWLEY \& BLACK (1985), a organização molecular das membranas é estabilizada em função da relação entre os componentes membranais e a água. Assim, tem sido demonstrado que, quando a hidratação da membrana é inferior a $25 \%$, verifica-se um rearranjo das moléculas da camada lipídica dupla, formando um canal em função da organização das cabeças polares dos fosfolipídios, que permite a penetração de água e, consequentemente, a perda de lixiviados. Esse rearranjo foi chamado por LUZZATI \& HUSSON (1962) e STOECKENIUS (1962) de fase hexagonal, enquanto a fase mais encontrada em seus estudos foi a fase de perfeita organização, chamada fase lamelar.

A perda da integridade das membranas está intimamente envolvida no processo de deterioração (BEWLEY \& BLACK, 1985). BASAVARAJAPPA et al. (1991) relacionam perda de integridade das membranas ao decréscimo no nível de 
fosfolipidios, à reduzida atividade de peroxidases e ascorbato e acréscimo no nível de ácidos graxos livres totais e malonaldeídos, em adição a formação de lipídios conjugados. O decréscimo no conteúdo de reservas alimentares como carboidratos, proteínas e fosfolipídios que ocorrem com o envelhecimento artificial poderia ser também atribuído à perda de integridade da membrana. O mecanismo provavelmente envolvido na deterioração de sementes seria a produção de radicais livres como um resultado da peroxidação de lipídios durante o envelhecimento e a reação com os lipídios membranais, e por fim, a destruição da estrutura das membranas celulares e a desnaturação das reservas alimentares.

No entanto, segundo ROBERTS (1981) as sementes que possuem tegumento impermeável à água (sementes duras) nas quais há uma proteção à umidade relativa do ar e à pressão normal de oxigênio, são uma possível exceção à suscetibilidade à deterioração. FOOD \& SINCLAIR (1981) examinaram a diferença no conteúdo de ácidos graxos insaturados de sementes permeáveis e impermeáveis de Trifolium subterraneum L. com 20 anos, e compararam-nas com recém colhidas. Ao contrário das sementes com tegumento impermeável, as permeáveis tinham conteúdos muito baixos de ácidos graxos insaturados, o que condiz, com uma teoria muito aceita, na qual o envelhecimento é, ao menos em parte, devido a autoxidação de ácidos graxos.

Segundo CARVALHO (1994) o monitoramento de lipídios tem levado à resultados conflitantes. Entre os que encontraram evidências de redução no conteúdo destacam-se HARMAN \& MATTICK (1976), FLOOD \& SINCLAIR (1981) e BASAVARAJAPPA et al. (1991).

HARMAN \& MATTICK (1976) demonstraram, em sementes de ervilha, que o processo de deterioração acarreta redução nos níveis de ácidos linoléico e 
linolênico, resultado esse também encontrado por STEWART \& BEWLEY (1980) trabalhando com sementes de soja submetidas a envelhecimento artificial. Os resultados sugeriram que o envelhecimento leva a reações peroxidativas em lipídios e que isto poderia contribuir para a perda de viabilidade. POWELL \& MATTHEWS (1981) mostraram que sementes de ervilha, nos estágios iniciais de deterioração, exibiram impossibilidade de retenção de solutos, que foram associados com a queda no conteúdo total de fosfolipídios e com variações em fosfolipidios específicos.

Alguns autores, no entanto, não relacionaram qualquer modificação nos níveis de fosfolipídios e ácidos graxos insaturados, sugerindo que a oxidação de lipídios não se correlaciona com deterioração (PRIESTLEY \& LEOPOLD, 1979; PRIESTLEY et al., 1980, PEARCE \& ABDEL SAMAD, 1980; OHLROGGE \& KERNAN, 1982; POWELL \& HARMAN, 1985).

No entanto, POWELL \& HARMAN (1985) questionaram se as mudanças que ocorrem durante o envelhecimento artificial refletem aquelas que ocorrem naturalmente Nesse sentido, PRIESTLEY \& LEOPOLD (1983), observaram que em sementes de soja sob envelhecimento natural há grande associação entre o declínio de vigor e o decréscimo do teor de ácidos graxos polinsaturados; sob envelhecimento artificial, nenhuma mudança foi detectada Concluíram, então, que o envelhecimento artificial é limitante para estudos deste tipo. PRIESTLEY et al (1985) observaram que sob envelhecimento natural não houve modificação nos níveis de radicais livres, enquanto sob condições de envelhecimento artificial seus niveis praticamente duplicaram.

WILSON \& MCDONALD (1986) propuseram maior atenção aos niveis de peroxidação de lipídios para explicar a deterioração de sementes. Isto inclui 
degradação da membrana, desnaturação de proteinas, interferência com DNA e síntese de proteínas, acumulação de material tóxico e destruição do transporte eletrônico da fosforilação oxidativa.

A embebição é acompanhada pela liberação de açúcares, aminoácidos e íons, em quantidades variáveis de acordo com o estado de organização dos sistemas de membranas celulares (SIMON \& RAJA HARUN, 1972; ABDUL-BAKI \& BAKER, 1973; BEWLEY \& BLACK, 1985). As taxas de liberação de solutos e de absorção de água são muito elevadas no início do processo de embebição, declinando posteriormente à medida em que ocorre a reorganização das membranas (PARRISH \& LEOPOLD, 1977; ABDEL SAMAD \& PEARCE, 1978; SIMON \& MATHAVAN, 1986). Para MURPHY \& NOLAND (1982) a membrana está envolvida tanto na absorção de água como na perda de solutos.

Embebição, a absorção de água por sementes secas, envolve absorção de água pelas paredes celulares e macromoleculas protoplasmáticas, por exemplo, proteínas e polissacarídeos, onde moléculas de água são "presas" por forças eletrostáticas tais como ligações de hidrogênio. O movimento de água dentro das sementes é devido à difusão e capilaridade, com a água movendo-se de regiões de maior para as de menor potencial. Dos três componentes do potencial hídrico (osmótico, mátrico e pressão de turgescência) é o potencial mátrico das células da parede e seus componentes o principal responsável pela embebição. O principal mecanismo de controle da taxa de absorção de água é a permeabilidade da testa ou tegumento da semente (WOODSTOCK, 1988). Assim, POWELL \& MATTHEWS (1978) verificaram, com sementes de ervilha, que aquelas 
embebidas com a testa, não apresentaram áreas mortas nos cotilédones, ao contrário daquelas que foram embebidas sem a testa. Foi verificado, também, que rupturas da testa poderiam causar morte às células por aumentar a intensidade de absorção de água (POWELL \& MATTHEWS, 1979).

LARSON (1968) verificou que a remoção do tegumento provoca rápida embebição, resultando em injúria e perda de solutos, pois há ruptura na organização da membrana levando à redução no crescimento de plântulas. Já ABDEL SAMAD \& PEARCE (1978) verificaram maior lixiviação em sementes sem testa e diferenças na composição dos lixiviados. O padrão de absorção de água não foi influenciado pelo tegumento.

MATTHEWS \& ROGERSON (1976), trabalhando com diferentes lotes de sementes de ervilha, concluíram que a lixiviação de solutos estava relacionada com a condição do embrião e não à condição da testa; sementes apresentando áreas de tecido morto lixiviavam mais; porém, a diferenciação entre os lotes se deu por diferenças no padrão de lixiviação de tecidos vivos.

POWELL et al (1986) mostraram evidências de danos após embebição de sementes de feijão na forma de morte de tecidos e aumento na lixiviação de solutos Membranas de sementes sensiveis à desidratação foram afetadas quando as sementes estavam com grau de umidade inferior a um nível crítico, que depende da espécie (BECWAR et al,, 1982), o que, pelo menos em parte, explica que sementes mais secas liberam mais exsudatos (PARRISH \& LEOPOLD, 1977). A liberação de solutos durante a embebição se deve à difusão passiva de solutos de baixo peso molecular e lixiviação de 
macromoléculas por ruptura celular (DUKE et al., 1983). SCHOETTLE \& LEOPOLD (1984) verificaram aumentos na lixiviação com o aumento de áreas contendo células danificadas. Embora a causa principal do baixo vigor seja aparentemente a incidencia de danos à testa por embebição rápida, morte de células e lixiviação de solutos, a condição do embrião também influencia a absorção de água e a lixiviação de solutos (MATTHEWS \& ROGERSON, 1976; POWELL \& MATTHEWS, 1979).

Dentre outros sinais, o dano às membranas celulares é uma das conseqüências do armazenamento prolongado. Sementes velhas, quando colocadas para embeber, perdem solutos mais rapidamente que as mais novas, o que também ocorre em sementes com maior intensidade de injúrias celulares (SCHOETTLE \& LEOPOLD, 1984).

Muitas alterações bioquímicas ocorrem nas sementes quando elas perdem vigor e muitas delas podem ser associadas com mudanças nas propriedades da membrana de uma ou mais organelas (ABDUL-BAKI \& BAKER, 1973), O decréscimo no vigor e na germinação são diretamente proporcionais ao aumento na lixiviação de solutos celulares das sementes, sugerindo uma intima relação entre a integridade das membranas e a perda do vigor e da germinação (WOODSTOCK, 1973; MOSS \& MULLETT, 1982; MURPHY \& NOLAND, 1982; SCHOETTLE \& LEOPOLD, 1984; ALIZAGA L. et al., 1990; LIN, 1990; MARCOS FILHO et al., 1990).

Para WOODSTOCK (1973), a lixiviação de metabólitos dos tecidos da semente pode ser inversamente associada ao vigor, com base em três fatores: a) reflete a perda de integridade da membrana; b) representa a perda de constituintes essenciais da célula, e c) liberação de substrato para o desenvolvimento de microrganismos. 


\subsection{Testes para avaliação rápida da qualidade fisiológica}

A avaliação da qualidade de sementes tem merecido permanente atenção dos tecnologistas, produtores e pesquisadores, refletindo o refinamento da demanda pela utilização de materiais que proporcionem maior segurança para fins de semeadura e/ou armazenamento (HAMPTON \& COOLBEAR, 1990).

A qualidade das sementes é determinada por fatores genéticos, fisicos, fisiológicos e sanitários. A qualidade fisiológica tem sido um dos aspectos mais pesquisados há vários anos, em decorrência das sementes estarem sujeitas a uma série de alterações degenerativas após a maturidade (ABDUL-BAKI \& ANDERSON, 1972)

Segundo HAMPTON \& COOLBEAR (1990), em função das limitações do tempo requerido para o teste de germinação, tem sido contínuo o interesse, nos últimos 25 anos, pelo potencial das propriedades físiológicas e bioquímicas das sementes como índices de vigor.

O vigor de um lote de sementes não é determinado por uma característica em particular, mas por um conjunto delas associadas ao desempenho das sementes (PERRY, 1981). Várias classificações para os testes de vigor têm sido propostas e relatadas com finalidade principalmente didática (WOODSTOCK, 1973; McDONALD Jr, 1975; VIEIRA et al, 1994), Parece pouco provável que um único teste, quer germinativo, fisiológico ou bioquímico, seja apropriado sob todas as condições, mesmo para uma única espécie (HAMPTON \& COOLBEAR, 1990; MARCOS FILHO, 1994b). MARCOS FILHO et al. (1990), trabalhando com três cultivares de soja, cada qual 
representado por sete lotes, concluíram que as avaliações do potencial físiológico das sementes em laboratório devem ser baseadas no conjunto dos resultados de diferentes testes.

Um teste de vigor, segundo TEKRONY (1972) e HAMPTON \& COOLBEAR (1990) deve, basicamente: a) registrar índices de qualidade de sementes mais sensíveis que o teste de germinação; b) separar lotes de sementes em termos de potencial de desempenho; c) ser objetivo, rápido, simples e economicamente viável; d) ser reproduzivel e interpretável de maneira objetiva. Para possuir boa receptividade entre os tecnologistas de sementes, deve ser reproduzível e relacionado com a emergência em campo, além de rápido, não oneroso, objetivo e de fácil execução, conforme McDONALD Jr. (1975) e MATTHEWS (1981).

A indústria de sementes frequentemente exige decisões rápidas, referentes ao manejo durante a colheita, recepção, processamento, armazenamento e comercialização, de modo que a necessidade da redução no período destinado à avaliação da qualidade fisiológica das sementes é considerada uma prioridade para a pesquisa.

Neste sentido, tem-se procurado desenvolver testes que possam ser usados para estimar mais rapidamente o comportamento de lotes quanto à viabilidade e vigor ou possam ser auxiliares em rotinas de laboratório.

Assim, através do exame da literatura sobre o assunto, observa-se que, atualmente, os testes rápidos mais estudados e desenvolvidos, avaliam principalmente os eventos iniciais da seqüência de deterioração proposta por DELOUCHE \& BASKIN (1973), baseando-se na redução das atividades respiratórias e biossintéticas (teste de tetrazólio) ou 
na permeablidade das membranas celulares, envolvendo parâmetros relacionados à liberação de metabólitos durante a embebição das sementes.

Apesar das pesquisas com estes testes serem relativamente recentes, alguns deles já estão sendo utilizados com sucesso em muitos laboratórios. TEKRONY (1983) relatou um levantamento feito, em 1982, com 102 laboratórios de análise de sementes nos EUA, onde se verificou que $61 \%$ dos mesmos usavam testes de vigor, destacando-se o teste de tetrazólio (66\% dos laboratórios) e o de condutividade elétrica $(31 \%)$

No Brasil, KRZYZANOWSKI \& MIRANDA (1990) em relatório do comitê de vigor da ABRATES, no qual foi feito uma aferição de testes de vigor para sementes de soja, entre 16 laboratórios, relataram que os testes de tetrazólio e condutividade elétrica poderiam ser usados rotineiramente pelos laboratórios, com a ressalva que os analistas do teste de tetrazólio deveriam participar rotineiramente de reciclagem para correção de desvios.

Pesquisas realizadas com diferentes espécies têm mostrado que o decréscimo na germinação e no vigor é diretamente proporcional ao aumento da lixiviação de solutos, indicando que a condutividade elétrica é um método eficiente para a avaliação do vigor Dentre os trabalhos mais recentes destacam-se os de MULLETT \& WILKINSON (1979) e GORECKI et al (1985) com ervilha; SCHOETTLE \& LEOPOLD (1984), MARCOS FILHO et al (1986, 1990), LOEFFLER et al. (1988) e DIAS (1994) com soja; SIDDIQUE \& GOODWIN (1985) e LIN (1990) com feijão; WOODSTOCK et al. (1985) com algodão e BRUGGINK et al. (1991) com milho. 
Alguns autores, no entanto, não encontraram boas relações entre perda de eletrólitos e vigor ou viabilidade; dentre estes, podemos citar HALLOIN (1975) com algodão, HALDER \& GUPTA (1980) com girassol e FERRISS \& BAKER (1990) com onze lotes de sementes de soja.

Além da condutividade elétrica, os exsudatos têm também sido avaliados através da quantidade de açúcares (ABDUL-BAKI \& ANDERSON, 1970; YAKLICH \& ABDUL-BAKI, 1975; MCKERSIE \& STINSON, 1980; SREERAMULU, 1983; PANDEY, 1989b), açúcares pelo teste "Tes-tape" usado para análise de urina (TAKAYANAGI \& MURAKAMI, 1968; MATTHEWS \& CARVER, 1971; TAKESHITA \& KONNO, 1985), carboidratos (SHORT \& LACY, 1976), ácidos orgânicos (SUBRAHMANYAM et al., 1983), compostos fenólicos (PANDEY, 1989a), fosfatos totais (MCKERSIE \& STINSON, 1980; MADHUSUDANAN \& JOHNSON, 1990), exudatos voláteis (GORECKI et al., 1985), pH do exsudato (AMARAL \& PESKE, 1984; BARROS \& MARCOS FILHO, 1990), radioatividade do exsudato (YAKLICH et al, 1979), aminoácidos (YAKLICH \& ABDUL-BAKI, 1975; McKERSIE \& STINSON, 1980; SREERAMULU, 1983; PANDEY, 1989b; LEE \& KARUNANITHY, 1990; ALIZAGA et al., 1990), radicais orgânicos livres (HEPBURN et al., 1986), densidade óptica dos exsudatos à 260 nm (DESWAL \& SHEORAN, 1993), lixiviação em água quente (PANDEY, 1988a; PANDEY, 1988b), proteínas (McKERSIE \& STINSON, 1980; LEE \& KARUNANITHY, 1990) e quanto à minerais como $\mathrm{K}, \mathrm{Mg}, \mathrm{Cl}, \mathrm{Ca}$ (GIVELBERG et al., 1984; GRANQVIST, 1987), K, Mg, Cl, Ca e Mn (LOOMIS \& SMITH, 1980; LOTT et al., 1991), K e P (PANDEY, 1989a; PANDEY, 1989b), K e Ca (WOODSTOCK et al., 1985) 
e apenas K (SIMON \& RAJA HARUN, 1972; MOSS \& MULLETT, 1982; MARCOS FILHO et al., 1984; SIMON \& MATHAVAN, 1986; WEGES \& KARSSEN, 1990; DIAS, 1994).

A condutividade elétrica, cuja base teórica está na permeabilidade das membranas, tem mostrado boa relação com a emergência das plântulas em campo e separação de lotes em diferentes níveis de qualidade (DIAS, 1994), tanto que estes têm sido a maior causa do seu emprego em pesquisa. Porém, outras utilizações foram verificadas na literatura como para indicar o grau de dormência em sementes de amendoim (SWAMY \& NARASIMHA REDDY, 1977) ou os efeitos da nutrição da planta mãe, em ervilha, sobre o vigor da semente produzida, que foi verificado através da condutividade dos lixiviados por HADAVIZADEH \& GEORGE (1988), enquanto VIEIRA et al. (1992), usou a condutividade elétrica para avaliar o efeito da desfolha e da deficiência hídrica na produção de sementes de soja. KUO (1989) utilizou a condutividade elétrica como método para separação de sementes duras de soja, para fins de melhoramento genético. A separação de -genótipos de milho doce, que apresentam problemas com a qualidade fisiológica das sementes, foi feita com sucesso através de condutividade elétrica (WANN, 1986; TRACY \& JUVIK, 1988).

A pesquisa tem demonstrado que vários fatores podem afetar os resultados do teste, tais como: idade da semente, genótipo, qualidade da água, temperatura e duração do período de embebição, grau de umidade e número de sementes (YAKLICH \& ABDUL-BAKI, 1975; SHORT \& LACY, 1976; MARBACH \& MAYER, 1985; VIEIRA, 1994). MURPHY \& NOLAND (1982) ressaltam que o efeito da temperatura sobre 
a embebição e lixiviação pode estar relacionado com alterações na viscosidade da água, interferindo tanto na quantidade como na velocidade de liberação dos exsudatos.

Para espécies de sementes grandes, como é o caso da ervilha e soja, tem-se recomendado um período de embebição de 24 horas (KRZYZANOWSKI et al, 1991; VIEIRA, 1994). Porém, devido a necessidade de obtenção de respostas mais rápidas tem-se tentado reduzir o tempo de embebição para leitura da condutividade elétrica. BROUWER \& MULDER (1982) trabalhando com feijão, encontraram resultados consistentes com 4 horas de embebição que se assemelharam aos resultados obtidos com 24 horas, concluindo que este seria um método mais rápido para detectar a baixa qualidade de lotes de sementes. MARCOS FILHO et al. (1990) concluíram que períodos mais curtos (4 e 8 horas) podem ser utilizados para identificação de diferenças mais acentuadas de vigor em sementes de soja, enquanto a embebição mais prolongada torna esse teste mais sensível às diferenças de vigor. Mais recentemente, DIAS (1994), em trabalho dentro da mesma linha, concluiu que este período deveria ser maior ( 8 e 12 horas) para apresentar resultados consistentes.

O teor de água das sementes, por ocasião do início da instalação do teste, é um fator muito importante pois, em geral, tem-se observado que o teor de água de sementes de soja, no início do teste, deve se situar entre 11 e 17\% (AOSA, 1983). Quando o teor de água se situa abaixo de $11 \%$, o valor da condutividade elétrica aumenta significativamente (LOEFFLER et al., 1988).

Um fator bastante desfavorável ao teste de condutividade elétrica, no entanto, é a dependência de regulagem do aparelho em relação à temperatura da solução onde estão as sementes, ou seja, da temperatura de embebição. LOEFFLER et al. (1988), 
indicaram que a temperatura de embebição deveria ser mais próxima da temperatura ambiente, ou seja, $25^{\circ} \mathrm{C}$ (até então, era recomendado $20^{\circ} \mathrm{C}$ ) e que deveria se retirar da câmara de embebição apenas as amostras suficientes para serem avaliadas em 15 minutos. Citaram, ainda, que variações de $5^{\circ} \mathrm{C}$ na temperatura da água de embebição afetaram a leitura da condutividade.

\subsubsection{Teste de lixiviação de potássio}

Segundo MARCOS FILHO et al. (1982), QUEIROGA \& PARRA (1989) e PRETE (1992), grande parte da condutividade elétrica se deve à lixiviação de íons potássio. Para QUEIROGA \& PARRA (1989) o potássio foi o elemento inorgânico que mais contribuiu (95\%) para o aumento da condutividade elétrica da solução procedente das sementes de girassol. A lixiviação de $\mathrm{Na}$ e a de $\mathrm{Ca}$ foram, respectivamente, 10 e 100 vezes menores que a de potássio. Trabalhando com sementes de repolho, LOOMIS \& SMITH (1980) determinaram que após 16 horas de embebição, $65 \%$ do potássio havia sido lixiviado das sementes submetidas a envelhecimento artificial. Em sementes de cenoura, GRANQVIST (1987), determinou que as perdas de potássio e cálcio foram da mesma magnitude, porém, muito maiores que as perdas de sódio e magnésio. LOTT et al. (1991), trabalhando com uma série de espécies, com sementes integras ou com partes de sementes, relataram que o potássio foi mais lixiviado que outros elementos. LEE \& KARUNANITHY (1990) analisando as perdas de elementos minerais durante a germinação de sementes de feijão e soja, verificaram que as perdas de $\mathrm{K}$ foram muito altas enquanto a perda de metais 
bivalentes como $\mathrm{Ca}, \mathrm{Fe}$ e $\mathrm{Mg}$ foram apenas moderadas, provavelmente devido a habilidade de formarem complexos com proteínas e ácido fítico. Outro trabalho, verificando as perdas de minerais em plântulas, associaram a perda de $\mathrm{K}$ aos danos a permeabilidade da membrana sendo estes danos relacionados a deficiência de Ca (WOOD, 1990).

A ligação entre lixiviação de minerais e danos à membrana é estreita, como já foi ressaltado anteriormente; WOODSTOCK et al. (1985) após terem confirmado a deterioração às membranas em sementes de algodão, através de microscopia eletrônica, ressaltaram que a lixiviação de minerais individuais, como $\mathrm{K}$ e $\mathrm{Ca}$, foram melhores indicadores da qualidade das sementes que índices gerais como a condutividade.

Algumas pesquisas têm relacionado os resultados do teste de lixiviação de potássio ao de condutividade elétrica (SIMON \& RAJA-HARUN, 1972; PANDEY, 1989b; DONI FILHO, 1992; PRETE, 1992; DIAS, 1994). O teste de lixiviação de potássio, segundo outras pesquisas, tem apresentado resultados relevantes para discriminar o potencial fisiológico de lotes de sementes (MATTHEWS \& ROGERSON, 1976; MARCOS FILHO, 1979; MARCOS FILHO et al., 1982; MOSS \& MULLETT, 1982; SREERAMULU, 1983; DIAS, 1994). A perda de K também tem sido usada para verificar o efeito do revigoramento das sementes ou "priming", como nos trabalhos de PANDEY (1989a), WEGES \& KARSEN (1990) e DONI FILHO (1992). A maioria dos trabalhos revisados relacionam a maior lixiviação de $\mathrm{K}$ com sementes de menor qualidade fisiológica, quer essa perda de qualidade tenha sido provocada por envelhecimento natural (MATTHEWS \& ROGERSON, 1976; SREERAMULU, 1983; WOODSTOCK et al., 1985; PANDEY, 1989b), ou artificial (LOOMIS \& SMITH, 1980) ou ainda por dano térmico 
durante a embebição (GIVELBERG, 1984). Alguns trabalhos, no entanto, não encontraram relações satisfatórias entre as maiores perdas de $\mathrm{K}$ durante a embebição e baixa qualidade de lotes de sementes (MARCOS FILHO et al., 1984; BARROS, 1988).

O padrão de lixiviação de potássio segundo SIMON \& MATHAVAN (1986) está diretamente relacionado ao padrão de embebição da semente e, este, ao tamanho da semente. Foi avaliada a porcentagem de potássio lixiviado em 24 horas e o tempo para lixiviação de $90 \%$ do potássio contido nas sementes. Os resultados demonstraram que, quanto menor a semente, mais rápida é a embebição e, também, a lixiviação de potássio. QUEIROGA \& PARRA (1989) ressaltaram a influência do peso da semente sobre a lixiviação de potássio, mostrando que as mais pesadas apresentaram valores mais altos de lixiviação.

Durante o processo de embebição das sementes é importante a temperatura, pois em temperaturas mais baixas o processo de reorganização das membranas é mais lento e isto aumenta o período em que as sementes perdem lixiviados, ou, em altas temperaturas, ocorre dano térmico às membranas, o que provoca grande aumento na lixiviação (GIVELBERG, 1984).

Nos primeiros experimentos com lixiviação de potássio, no entanto, os autores trabalharam com temperatura ambiente, como AMORIM (1978) e MARCOS FILHO (1979), obtendo resultados promissores para o teste. Seguiram-se, então, outras pesquisas com controle de temperatura durante a embebição.

Assim, trabalharam com $30^{\circ} \mathrm{C}$, MARCOS FILHO et al. $(1982,1984)$, BARROS (1988) e DIAS (1994). Resultados muito importantes foram obtidos por 
MARCOS FILHO et al. (1982), onde a lixiviação de potássio decresceu à medida em que elevaram-se o poder germinativo e o vigor de sementes de soja durante o processo de maturação e também por DIAS (1994), onde o teste foi considerado promissor para avaliação do vigor de sementes de soja. Tem-se trabalhado também com $20^{\circ} \mathrm{C}$ e $25^{\circ} \mathrm{C}$; DONI FILHO (1992) trabalhou com $20^{\circ} \mathrm{C}$ e obteve bons resultados ao utilizar o teste de lixiviação de potássio para verificar os efeitos do condicionamento fisiológico em sementes de feijão. Já PRETE (1992) utilizou $20^{\circ} \mathrm{C}$ e $25^{\circ} \mathrm{C}$, mas preferiu trabalhar com $25^{\circ} \mathrm{C}$ para avaliar as relações entre a lixiviação de potássio e a qualidade da bebida de café, observando que cafés de piores bebidas apresentam altos padrões de lixiviação.

O período de tempo para realização da leitura da lixiviação está relacionado com o objetivo do teste. Quando o objetivo foi verificar a relação da qualidade de bebida do café com lixiviação de potássio (AMORIM, 1978) e daquela com condutividade elétrica do exsudato e lixiviação de potássio (PRETE, 1992) os tempos são mais longos. AMORIM (1978) estabeleceu melhores diferenças entre os tratamentos trabalhando com 90 minutos e PRETE (1992) determinou que a melhor separação se dava às 3,5 horas para a condutividade elétrica e 3,0 horas para a lixiviação de potássio. Quando o interesse está em verificar o potencial físiológico de lotes os tempos para realização da leitura tem variado. Intervalos longos, como 72 horas, foram estudados por MOSS \& MULLETT (1982). Porém, tem sido mais utilizado o período de 90 minutos como nos trabalhos de MARCOS FILHO (1979), MARCOS FILHO et al. (1982) com resultados muito promissores e MARCOS FILHO et al. (1984) e BARROS (1988), que não obtiveram bons resultados ao avaliarem comparativamente testes de vigor em soja. DIAS (1994) trabalhou com $60,90,120$ e 150 minutos, para verificar o tempo de embebição que mais se relacionava com o vigor de sementes de soja, e concluiu que 90 minutos era o mais 
adequado. Este resultado parece comprovar que as diferenças de lixiviação de $\mathbf{K}$ aparecem nos primeiros minutos após a embebição (MATTHEWS \& ROGERSON, 1976; SREERAMULU, 1983).

Outras variáveis presentes na metodologia do teste de lixiviação de potássio tem sido a quantidade de água e a quantidade de sementes utilizadas, que se apresentam interdependentes, pois estão diretamente relacionadas com a concentração da solução que será submetida à leitura e do método utilizado para leitura. É interessante uma combinação que possibilite leitura direta, sem diluição da solução.

Quanto ao método utilizado, a maioria dos autores tem realizado a leitura do potássio lixiviado através do fotômetro de chama (SIMON \& RAJA HARUN, 1972; SREERAMULU, 1983; GIVELBERG et al., 1984; QUEIROGA \& PARRA, 1989; PANDEY, 1989a; PANDEY, 1989b; WEGES \& KARSSEN, 1990); outros, porém, usaram o espectrofotômetro de absorção atômica (MATTHEWS \& ROGERSON, 1976; MOSS \& MULLETT, 1982; GRANQVIST, 1987; WOOD, 1990) e outros ainda, análise de ativação de neutrons (LOOMIS \& SMITH, 1980; LOTT et al., 1991), cuja metodologia é mais complexa. Segundo RODELLA \& BORGES (1989) a fotometria de chama é o único método viável para a determinação de potássio nas análises de rotina, devido principalmente a maior precisão, menor custo e maior simplicidade.

Verifica-se que o teste de lixiviação de potássio tem se mostrado um teste muito promissor, tendo como vantagem adicional a rapidez com que pode ser executado e a não interferência da temperatura da solução na leitura. No entanto, nota-se através da consulta à literatura a necessidade de continuidade das pesquisas no sentido de possibilitar a padronização do mesmo. 


\section{MATERIAL E MÉTODOS}

O presente trabalho foi conduzido no Laboratório de Análise de Sementes e no Campo Experimental do Departamento de Agricultura da Escola Superior de Agricultura "Luiz de Queiroz" da Universidade de São Paulo. Os testes foram conduzidos de julho de 1993 a julho de 1994, compreendendo três experimentos, sendo os dois primeiros, testes preliminares, e o último, o estudo do teste de lixiviação de potássio propriamente dito.

\subsection{Experimento I}

O experimento I teve por objetivo verificar a qualidade fisiológica inicial de lotes de sementes de soja, de quatro cultivares diferentes, para escolha de dois cultivares que apresentassem lotes com qualidade fisiologica diferenciada e com eles realizar o experimento III (estudo do teste de lixiviação de potássio em semente de soja). Utilizaram-se os cultivares BR 38 e BR 36 provenientes do IAPAR - Instituto Agronômico 
do Paraná e os cultivares IAC 15 e IAS 5 provenientes da Empresa Comércio e Indústria de Sementes Brejeiro, todos produzidos no ano agricola 1992/93, e cada qual representado por anco lotes. Os testes foram realizados durante os meses de julho/agosto de 1993

\subsubsection{Recepção das amostras}

Assim que os lotes foram recebidos, procedeu-se a homogeneização dos mesmos em divisor cônico, após a qual estes foram devidamente divididos para a caracterização geral através de testes de laboratório e de campo.

\subsubsection{Determinação do grau de umidade}

Foi efetuada em estufa a $105 \pm 3^{\circ} \mathrm{C}$ durante 24 horas, utilizando-se duas amostras para cada lote, de acordo com as Regras para Análise de Sementes - RAS (BR+SIL, 1992). Os resultados foram expressos em porcentagem média para cada lote.

\subsubsection{Teste de germinação}

Foi conduzido com quatro repetições de 50 sementes para cada lote, em germinador regulado para manter temperatura constante de $25^{\circ} \mathrm{C}$ durante o decorrer do teste. Foram utilizados como substrato rolos de papel GERMITEST; a quantidade de água adicionada ao substrato foi equivalente a 2,2 vezes o peso do substrato seco, visando o 
umedecimento adequado. As contagens foram feitas aos quatro e sete dias após a semeadura, computando-se as porcentagens de plàntulas normais de acordo com os critérios estabelecidos pela RAS (BRASIL, 1992)

\subsubsection{Envelhecimento acelerado}

Segundo metodologia recomendada pelo Comitê de Vigor da ASSOCIATION OF OFFICIAL SEED ANALYSTS (AOSA, 1983) e complementada por MARCOS FILHO et al. (1987) e KRZYZANOWSKI et al. (1991), foram utilizadas caixas de plástico (Gerbox) como compartimento individual. Assim, uma camada única de sementes de cada lote foi colocada sobre a tela metálica interna da caixa. As caixas, tampadas e contendo $40 \mathrm{ml}$ de água, foram mantidas em incubadora tipo $\mathrm{BOD}, \mathrm{a} 41^{\circ} \mathrm{C}$, durante $48 \mathrm{~h}$; em seguida, foi efetuado o teste de germinação, conforme descrição anterior, avaliando-se as porcentagens de plântulas normais no quarto dia após a semeadura.

Mediante o conhecimento do grau de umidade inicial de cada lote determinada em estufa à $105 \pm 3^{\circ} \mathrm{C}$ e sabendo-se o peso inicial e final das sementes colocadas na incubadora, moniorou-se o grau de umidade das sementes após o envelhecimento.

\subsubsection{Condutividade elétrica}

Foram utilizadas quatro amostras de 50 sementes fisicamente puras de cada lote, previamente pesadas e, a seguir, imersas em $75 \mathrm{ml}$ de água destilada (no 
interior de copos pásticos), a $25^{\circ} \mathrm{C}$, de acordo com LOEFFLER et al. (1988). A condutividade foi avaliada em aparelho DIGIMED CD-20. Os resultados foram expressos em $\mu \mathrm{mhos} / \mathrm{cm} / \mathrm{g}$ de semente

\subsubsection{Emergência das plântulas em campo}

Foi conduzido com amostras de 400 sementes para cada lote; cada parcela foi constituída por uma linha de 4,0m de comprimento, onde se distribuíram 50 sementes, em sulcos espaçados de $0,5 \mathrm{~m}$ com $0,05 \mathrm{~m}$ de profundidade. Após a distribuição das sementes os sulcos foram cobertos com aproximadamente $0,02 \mathrm{~m}$ de terra. As contagens do número de plântulas emersas foram efetuadas aos 15 dias após a semeadura, computando-se as porcentagens de plântulas com os cotilédones acima da superfície do solo e as folhas unifoliadas com margens não mais se tocando (corresponde ao estávio VC descrito por COSTA \& MARCHEZAN, 1982).

Os resultados obtidos no Experimento I foram analisados estatisticamente, seguindo delineamento inteiramente casualizado, de acordo com esquema apresentado na Tabela 1. Os resultados de germinação, envelhecimento acelerado e emergência das plântulas em campo foram transformados em arc sen $\sqrt{100 / x}$, enquanto os resultados de condutividade elétrica não sofreram transformação. Os dados referentes ao grau de umidade das sementes năo foram analisados estatisticamente; suas interpretações foram relacionadas apenas aos aspectos biológicos. 
Tabela 1. Esquema da análise da variância dos testes de laboratorio e de campo para cada cultivar, obtidos no Experimento I. Piracicaba, 1993.

Causas de variação

Graus de liberdade

\begin{tabular}{lc}
\hline & \\
Lotes & 4 \\
Resíduo & 15 \\
& \\
\hline
\end{tabular}

Total

19

A comparação múltipla de médias foi realizada através do teste de Tukey ao nível de 5\% de probabilidade. Para os cálculos estatísticos utilizou-se o Sistema de Análise Estatística - SANEST para microcomputadores (ZONTA et al., 1984).

\subsection{Experimento II}

Para determinar a melhor curva de calibração que deveria ser usada na avaliação de lixiviação de potássio das sementes, através de leitura em fotômetro de chama DIGIMED NK-2020, foram estabelecidas quatro curvas padrão de calibração.

Cada curva foi estabelecida através de regressão linear e avaliada com, no mínimo, seis observações. Foram elas: padrão 20 ppm de potássio ajustado para 
leitura 50 (curva 1); padrão 30 ppm de potássio ajustado para leitura 50 (curva 2); padrão 40 ppm de potássio ajustado para leitura 100 (curva 3); padrão 50 ppm de potássio ajustado para leitura 100 (curva 4). Em todas as curvas, foi feita uma observação com água destilada, ajustada para leitura zero. A seguir fizeram-se leituras com padrões de potássio de concentração conhecida e inferiores à calibração ajustada, para verificar a linearidade de cada curva.

Para avaliação das curvas, além da linearidade, foi feito um teste de lixiviação de potássio com dois cultivares, BR 38 e IAC 15, cada qual com cinco lotes. Os testes foram feitos durante o mês de setembro de 1993.

Para cada lote, foram separadas quatro repetições de 25 sementes tomadas ao acaso da porção de sementes puras, às quais adicionaram-se $75 \mathrm{ml}$ de água destilada (no interior de copos plásticos). A embebição foi feita a $30^{\circ} \mathrm{C}$ durante 30 minutos, após a qual as sementes foram retiradas da água de embebição. Procederam-se, assim, as leituras de lixiviação de potássio na água de embebição para as quatro curvas de calibração: curva 1 , curva 2 , curva 3 e curva 4

Observou-se a necessidade de diluição das amostras. Os resultados foram expressos em $\mathrm{ppm} \mathrm{K} / \mathrm{g}$ semente e comparados com os resultados obtidos no Experimento I e, assim, obteve-se uma resposta mais segura da melhor calibração do fotômetro de chama para o teste de lixiviação de potássio em sementes de soja.

A análise estatística seguiu delineamento inteiramente casualizado de acordo com esquema apresentado na Tabela 2 . Os dados de lixiviação de potássio não sofreram transformações. 
Tabela 2. Esquema de análise da variância dos dados de lixiviação de potássio obtidos no Experimento II para cada cultivar e curva padrão estudada. Piracicaba, 1993

Causas da variação

Graus de liberdade

Lotes

4

Resíduo

15

Total

19

Para comparação múltipla de médias utilizou-se o teste de Tukey ao nível de $5 \%$ de probabilidade. Os cálculos estatísticos foram realizados através do Sistema de Análise Estatística - SANEST para microcomputadores (ZONTA et al., 1984).

\subsection{Experimento III}

Esta fase foi conduzida avaliando-se os resultados do teste de lixiviação de potássio e os resultados fornecidos por outros testes considerados adequados para a determinação da qualidade fisiológica de sementes de soja. 
Os cultivares escolhidos para a condução da pesquisa foram BR 38 e IAC 15, conforme resultados do Experimento I, cada qual representado por cinco lotes. $\mathrm{O}$ estudo foi feito em três épocas de testes, em atervalos aproximadamente bimestrais, sendo a primeira em outubro/novembro de 1993, a segunda em fevereiro/março de 1994 e a última em junho/julho de 1994. Durante todo o período os lotes permaneceram armazenados em sacos de papel sob ambiente.

\subsubsection{Determinações complementares}

\subsubsection{Peso de 1000 sementes}

$O$ peso de 1000 sementes foi determinado utilizando-se oito repetições de 100 sementes tomadas da porção sementes puras, de acordo com as Regras para Análise de Sementes (BRASIL, 1992).

\subsubsection{Análise da composição química das sementes}

A análise foi realizada pelo Departamento de Química da Escola Superior de Agricultura "Luiz de Queiroz". Foram utilizadas $50 \mathrm{~g}$ de sementes por lote, e a determinação seguiu o método analitico descrito por SARRUGE \& HAAG (1974). 


\subsubsection{Teste de sanidade}

O teste foi realizado pelo Laboratório de Fitopatologia do Departamento de Fitopatologia da Escola Superior de Agricultura "Luiz de Queiroz". Foram utilizadas 100 sementes por lote, e a determinação seguiu o método do papel de filtro (LUCCA FILHO, 1987).

\subsubsection{Dados de temperatura e umidade relativa do ambiente de ammaenamento}

As sementes foram mantidas no ambiente do laboratório durante todo o período experimental. Os dados de temperatura e umidade relativa do ar foram registrados através de um higrotermógrafo.

\subsubsection{Teste de lixiviação de potássio}

Sementes fisicamente puras foram embebidas em dois volumes de água destilada: 75 e $100 \mathrm{ml}$. Foram utilizadas quatro repetições de 25 sementes por lote As leituras foram realizadas apos três períodos de embebição: 30,60 e 90 minutos. Desta forma, os tratamentos formaram-se pela combinação entre quantidades de água e períodos de embebição, ou seja: 


$$
\begin{aligned}
& \mathrm{T}_{1}: 75 \mathrm{ml} / 30 \mathrm{~min} \\
& \mathrm{~T}_{2}: 75 \mathrm{ml} / 60 \mathrm{~min} \\
& \mathrm{~T}_{3}: 75 \mathrm{ml} / 90 \mathrm{~min} \\
& \mathrm{~T}_{4}: 100 \mathrm{ml} / 30 \mathrm{~min} \\
& \mathrm{~T}_{5}: 100 \mathrm{ml} / 60 \mathrm{~min} \\
& \mathrm{~T}_{6}: 100 \mathrm{ml} / 90 \mathrm{~min}
\end{aligned}
$$

Duas temperaturas foram testadas para embebição: 25 e $30^{\circ} \mathrm{C}$. As leituras do potássio lixiviado das sementes foram feitas em fotômetro de chama DIGIMED NK-2020, calibrado com a curva 4 (padrão 50 ppm K para leitura 100) de acordo com resultados do Experimento II. Os resultados foram expressos em $\mathrm{ppm} \mathrm{K} / \mathrm{g}$ de amostra.

\subsubsection{Outras avaliações}

Para as avaliaçōes de determinação do grau de umidade, teste de germinação, envelhecimento acelerado, condutividade elétrica e emergência das plântulas em campo, foram seguidas, em cada época, a mesma metodologia proposta no Experimento I, itens $3.1 .2,3.1 .3,3.1 .4,3.1 .5$ e 3.1 .6

\subsubsection{Primeira contagem da germinação}

Foi conduzido conjuntamente com o teste de germinação, consistindo do registro das plântulas normais encontradas na primeira contagem do referido teste, feito no quarto dia após a semeadura. Os resultados foram expressos em porcentagem de plântulas normais. 


\subsubsection{Procedimento estatístico}

Os dados provenientes dos testes de germinação, primeira contagem de germinação, envelhecimento acelerado e emergència das plântulas em campo foram transformados em arc sen $\sqrt{x / 100}$, enquanto os de condutividade elétrica e lixiviação de potássio não sofreram transformações. Os resultados das determinações adicionais e do grau de umidade das sementes não foram analisados estatisticamente; suas interpretações foram relacionadas apenas aos aspectos biológicos.

Todos os dados foram analisados segundo delineamento inteiramente casualizado, segundo esquemas apresentados nas Tabelas 3 e 4 .

Tabela 3. Esquema da análise da variância dos dados de lixiviação de potássio para cada cultivar, temperatura de embebição e época de avaliação obtidos no Experimento III Piracicaba, 1993.

Causas de Variação

Graus de Liberdade

Tratamentos 5

Lotes 4

Tratamentos x Lotes $\quad 20$

Resíduo 90

Total 
Tabela 4. Esquema de análise da vanància dos dados de germinação, primeira contagem de germinação, envelhecimento acelerado, condutividade elétrica e emergència das plântulas em campo para cada cultivar e época de avaliação obtidos no Experimento III. Piracicaba, 1993.

Causas de Variação

Graus de Liberdade

Lotes

Resíduo
4

15

Total

19

Para comparação múltıpla de médias utilizou-se o teste de Tukey ao nível de $5 \%$ de probabilidade. Os cálculos estatisticos foram realizados através do Sistema de Análise Estatística - SANEST para micro-computadores (ZONTA et al., 1984). 


\title{
4. RESULTADOS E DISCUSSÃO
}

\author{
No presente capítulo serão discutidos os resultados referentes aos \\ testes empregados para avaliação da qualidade fisiológica de sementes, para cada \\ experimento.
}

\subsection{Experimento I}

Observando-se os valores de $\mathrm{F}$ obtidos nas análises da variància dos dados referentes aos testes de laboratório e de campo, realizados com os lotes dos quatro cultivares (Tabela 5), verificou-se que apenas os lotes do cultivar BR 38 apresentaram diferenças altamente significativas para todos os testes. Os lotes do cultivar BR 36 mostraram-se diferentes apenas no teste de envelhecimento acelerado, enquanto os lotes dos cultivares IAC 15 e IAS 5 não apresentaram diferenças em nenhum dos testes realizados. 
Tabela 5. Valores de $F$ obtidos nas análises da variância dos dados referentes aos testes de laboratóno e de campo, realizados com os lotes dos cultivares BR $38, \mathrm{BR}$ 36, IAC 15 e IAS 5 durante o experimento I. Piracicaba, 1993.

Cultivares

Germinação

Env.

Cond.

Emerg. pl.

acelerado

elétr.

em campo

\begin{tabular}{|c|c|c|c|c|}
\hline BR 38 & $5,4295^{* *}$ & $12,0924^{* *}$ & $9,3040 * *$ & $6,0318^{* *}$ \\
\hline BR 36 & $1,0032^{\mathrm{NS}}$ & $7,1811^{* *}$ & $0,8750^{\mathrm{NS}}$ & $0,4714^{\mathrm{NS}}$ \\
\hline IAC 15 & $3,3778^{: i s}$ & $1,7703^{\mathrm{NS}}$ & $0,9226^{\mathrm{sis}}$ & $1,0509^{\mathrm{ks}}$ \\
\hline IAS 5 & $0,8570^{.15}$ & $0,8110^{\text {ss }}$ & $1,0644^{\mathrm{Ns}}$ & $0,3398^{\text {vs }}$ \\
\hline
\end{tabular}

** Significativo ao nível de $1 \%$ de probabilidade.

is Não significativo.

\subsubsection{Cultivar BR 38}

A Tabela 6 mostrou que os lotes do cultivar BR 38 apresentaram-se, de uma maneira geral, com alta qualidade fisiológica, uma vez que, os valores do teste de germinação ficaram na faixa entre 85 e $97 \%$, onde os lotes 1 e 4 mostraram-se superiores ao lote 3 . Os lotes 2 e 5 não diferiram dos lotes 1 e 4, como também não diferiram do lote 3, embora em valores numéricos, ocorra uma tendência do lote 2 ser superior ao lote 5 . 
Tabela 6. Média dos resultados de germinação (G), envelhecimento acelerado (EA), condutividade elétrica (CE), emergência das plântulas em campo (EC) e umidade (U) para o cultivar BR 38, durante o experimento I. Piracicaba, 1993.

\begin{tabular}{lccccc}
\hline & G & EA & CE & EC & U \\
Lotes & $(\%)$ & $(\%)$ & $\mu$ mnhos/cm/g & $(\%)$ & $(\%)$ \\
& & & & & \\
\hline 1 & $95 \mathrm{a}^{1}$ & $97 \mathrm{a}$ & $60,87 \mathrm{ab}$ & $78 \mathrm{ab}$ & 9,8 \\
2 & $93 \mathrm{ab}$ & $91 \mathrm{bc}$ & $56,36 \mathrm{ab}$ & $79 \mathrm{ab}$ & 9,9 \\
3 & $85 \mathrm{~b}$ & $83 \mathrm{c}$ & $75,04 \mathrm{c}$ & $66 \mathrm{~b}$ & 9,8 \\
4 & $97 \mathrm{a}$ & $95 \mathrm{ab}$ & $50,98 \mathrm{a}$ & $81 \mathrm{a}$ & 9,1 \\
5 & $89 \mathrm{ab}$ & $91 \mathrm{ab}$ & $64,27 \mathrm{bc}$ & $66 \mathrm{~b}$ & 10,2 \\
\hline & & & & & \\
\hline
\end{tabular}

${ }^{t}$ Médias seguidas por letras distintas diferem entre si ao nível de $5 \%$ de significância.

Os testes de vigor, de maneira geral, confirmaram os resultados do teste de germinação, porém, os testes de envelhecimento acelerado e condutividade elétrica foram mais sensíveis em detectar diferenças de vigor que o teste de emergência das plàntulas em campo.

O teste de envelhecimento acelerado indicou o lote 1 como de qualidade físiológica superior aos demais, embora os lotes 4 e 5 não tenham diferido do lote 1 e do lote 2. Numericamente, no entanto, o lote 4 apresentou-se superior aos lotes 2 e 5 . O lote 3 apresentou o pior desempenho, embora não tenha diferido do lote 2. 
A condutividade elétrica destacou a qualidade físiológica do lote 4 em relação aos lotes 3 e 5 . Os lotes 1 e 2 não diferiram dos lotes 4 e 5 . O lote 3 foi classificado como sendo de pior qualidade embora não tenha diferido do lote 5

A emergência das plântulas em campo classificou os lotes em très niveis. O lote 4 apresentou qualidade destacada em relação aos lotes 3 e 5 que não diferiram entre si. Os lotes 1 e 2 também não diferiram entre si e foram classificados em posição intermediária, não diferindo do lote 4 e dos lotes 3 e 5, que apresentaram os índices mais baixos.

De maneira geral, houve concordancia entre os testes em indicar os lotes 1 e 4 como de qualidade superior e os lotes 3 e 5 como de qualidade inferior. Estes resultados indicam a adequação do uso de vários testes para a avaliação da qualidade fisiológica de sementes de soja (TEKRONY \& EGLI, 1977; KULIK \& YAKLICH, 1982; MARCOS FILHO et al., 1982; 1984 e MARCOS FILHO, 1994b).

\subsubsection{Cultivar BR 36}

Analisando-se a Tabela 7, observa-se que os lotes do cultivar BR 36 apresentaram um comportamento variado de acordo com o teste empregado, o que não permitiu uma boa classificação em niveis de vigor. Estatisticamente, apenas o teste de envelhecimento acelerado classificou os lotes, sendo que, o lote 1 apresentou qualidade fisiológica superior, diferindo dos lotes 3 e 4 . O lote 3 apresentou desempenho inferior, 
diferindo-se dos lotes 1 e 5.0 lote 4 não diferiu do lote 3 e o lote 2 não diferiu de nenhum dos lotes, apresentando portanto, um comportamento intermediário.

Tabela 7. Média dos resultados de germinação (G), envelhecimento acelerado (EA), condutividade elétrica (CE), emergència das plântulas em campo (EC) e umidade (U) para o cultivar BR 36, durante o experimento I. Piracicaba, 1993.

\begin{tabular}{|c|c|c|c|c|c|}
\hline \multirow{3}{*}{ Lotes } & G & $\mathrm{EA}$ & $C E$ & $\mathrm{EC}$ & U \\
\hline & & & & & \\
\hline & $(\%)$ & $(\%)$ & $\mu$ monhos $/ \mathrm{cm} / \mathrm{g}$ & $(\%)$ & $(\%)$ \\
\hline 1 & $87 a^{1}$ & $98 \mathrm{a}$ & $74.28 \mathrm{a}$ & $91 a$ & 10,5 \\
\hline 2 & $93 a$ & $94 a b e$ & $79.97 \mathrm{a}$ & $91 \mathbf{a}$ & 11,0 \\
\hline 3 & $90 a$ & $86 \mathrm{c}$ & $80,57 a$ & $94 a$ & 10,5 \\
\hline 4 & $87 a$ & $92 b c$ & $84,25 \mathrm{a}$ & $95 a$ & 10,6 \\
\hline 5 & $91 \mathrm{a}$ & $95 a b$ & $75,13 a$ & $90 \mathbf{a}$ & 11,1 \\
\hline $\operatorname{CV}(\%)$ & 6,8 & 5,1 & 11,3 & 8,3 & - \\
\hline
\end{tabular}

Medias seguidas por letras distintas diferem entre si zo nivel de $5 \%$ de significância.

O teste de condutividade elétrica demonstrou que, apesar de não ter havido diferenças estatísticas, os lotes 1 e 5 destacaram-se por apresentar bom desempenho, ao contrário do lote 4 . Os lotes 2 e 3 ocuparam posiçăo intermediária, o que, de maneira geral, apresentou concordância com os resultados do envelhecimento acelerado. Ao contrário destes, os testes de germinação e emergència revelaram resultados contraditórios. 
No teste de germinação, houve uma :endència do lote 2 destacar-se dos demais, enquanto os lotes 1 e 4 apresentaram desempenho inferior. Os lotes 3 e 5 apresentaram resultados intermediários. De uma maneira geral os resultados do teste de germinação demonstraram alta qualidade dos lotes, permanecen 30 na faixa de 87 a $93 \%$.

Já no teste de ミmergência em campo, apesar dos resultados bastante próximos, destacou-se numericamente o comportamento dos lotes 3 e 4 , que apresentaram desempenho inferior nos testes de envelhecimento acelerado e condutividade, como também não se destacaram no teste de germinação. Apesar disso, constataram-se altos valores de emergência das plântulas em campo para todos os lotes do cultivar BR 36, valores estes que variaram entre 90 e $95 \%$, superiores aos resultados obtidos com os outros cultivares. o que indicou alto potencial fisiológ: co destes lotes e grande proximidade de resposta, ou seja, mínimas diferenças fisiológicas entre eles. De fato, a separação dos lotes de sementes apresentando diferenças de qualidade pouco acentuadas foi considerada problemática por diversos autores (KULIK \& YAKLICH, 1982; MARCOS FILHO et al., 1984; 1986).

\subsubsection{Cultivar IAC 15}

Os lotes do cuitivar IAC 15 (Tabela 8) não diferiram estatisticamente em nenhum dos testes realizados. A análise dos valores numéricos, no entanto, permitem algumas considerações. A germinaçào dos lotes foi satisfatória, variando entre 84 e $93 \%$, sendo que, o lote com maior germinação foi o 5 . Os lotes 1 e 2 alcançaram $84 \%$, que foram os valores mais baixos. No entanto, quando se considerou a emergência das plàntulas 
em campo, notou-se que os resultados foram inferiores aos de germinação, demonstrando o menor potencial fisiológico dos lotes para suportar condições mais severas. O lote 5 que apresentou a maior germinação, respondeu com o pior desempenho em relação ao número de plântulas emersas em campo

Tabela 8. Média dos resultados de germinação(G), envelhecimento acelerado (EA), condutividade elétrica (CE), emergência das plântulas em campo (EC) e umidade (U) para o cultivar IAC 15, durante o experimento I. Piracicaba, 1993.

\begin{tabular}{lccccc}
\hline & $G$ & EA & CE & EC & U \\
Lotes & $\%$ \%) & $(\%)$ & $\mu$ mnhos/cm/g & $(\%)$ & $(\%)$ \\
& & & & & \\
\hline 1 & $84 a^{1}$ & $91 \mathrm{a}$ & $90,63 \mathrm{a}$ & $62 \mathrm{a}$ & 9,1 \\
2 & $84 \mathrm{a}$ & $85 \mathrm{a}$ & $88,22 \mathrm{a}$ & $61 \mathrm{a}$ & 9,4 \\
3 & $87 \mathrm{a}$ & $91 \mathrm{a}$ & $93,24 \mathrm{a}$ & $67 \mathrm{a}$ & 9,4 \\
4 & $91 \mathrm{a}$ & $92 \mathrm{a}$ & $91,93 \mathrm{a}$ & $63 \mathrm{a}$ & 9,9 \\
5 & $93 \mathrm{a}$ & $85 \mathrm{a}$ & $\mathbf{8 7 , 2 2 \mathrm { a }}$ & $58 \mathrm{a}$ & 10,5 \\
\hline $\mathrm{CV}(\%)$ & & & & & \\
\hline
\end{tabular}

\footnotetext{
${ }^{1}$ Médias seguidas por letras distintas diferem entre si ao nivel de $5 \%$ de significância.
}

Quanto aos outros testes de vigor, observou-se que os resultados do envelhecimento acelerado demonstraram uma tendência semelhante aos da emergência das plântulas em campo, apenas incluindo o lote 2 com o lote 5 , em termos de pior 
desempenho. Já o teste de condutividade eletrica, apresentou tendência inversa, ou seja. com os resultados mais próximos aos revelados pela germinação, indicando o lote 5 e também o lote 2 como apresentando potencial fisiológico superior.

De maneira geral, os lotes do cultivar IAC 15 apresentaram diferentes comportamentos entre si, porém esta diferença não foi revelada de forma coerente entre os testes utilizados. Sabe-se que o histónico de cada lote interfere na sua maior ou menor sensibilidade às diferentes condições a que é submetido em cada teste (KULIK \& YAKLICH, 1982), o que pode explicar a falta de coerência entre os resultados dos diferentes testes.

\subsubsection{Cultivar IAS 5}

O teste de germinação revelou um comportamento bastante homogêneo entre os lotes do cultivar IAS 5 pois os dados variaram entre 91 e $95 \%$, mostrando, portanto, a alta qualidade dos lotes. Assim como aconteceu com o cultivar IAC 15 , os lotes do cultivar IAS 5 também não apresentaram diferenças estatísticas em nenhum dos testes utilizados.

O teste de envelhecimento acelerado apresentou resultados variando de 89 a 92\%, o que, representou proximidade dos lotes, em termos de qualidade fisiológica. Os testes de condutividade elétrica e emergência das plântulas em campo mostraram a mesma tendência dos testes já comentados, o que impediu qualquer tentativa de distingüilos em termos de potencial fisiológico. Isto se deve, provavelmente, à dificuldade já 
relatada na literatura (KULIK \& YAKLICH, 1982; MARCOS FILHO et al., 1984; 1990) de serem detectadas diferenças de qualidade entre amostras com níveis próximos de vigor.

Tabela 9. Média dos resultados de germinação (G), envelhecimento acelerado (EA). condutividade elétrica (CE), emergência das plântulas em campo (EC) e umidade (U) para o cultivar IAS 5, durante o experimento I. Piracicaba. 1993.

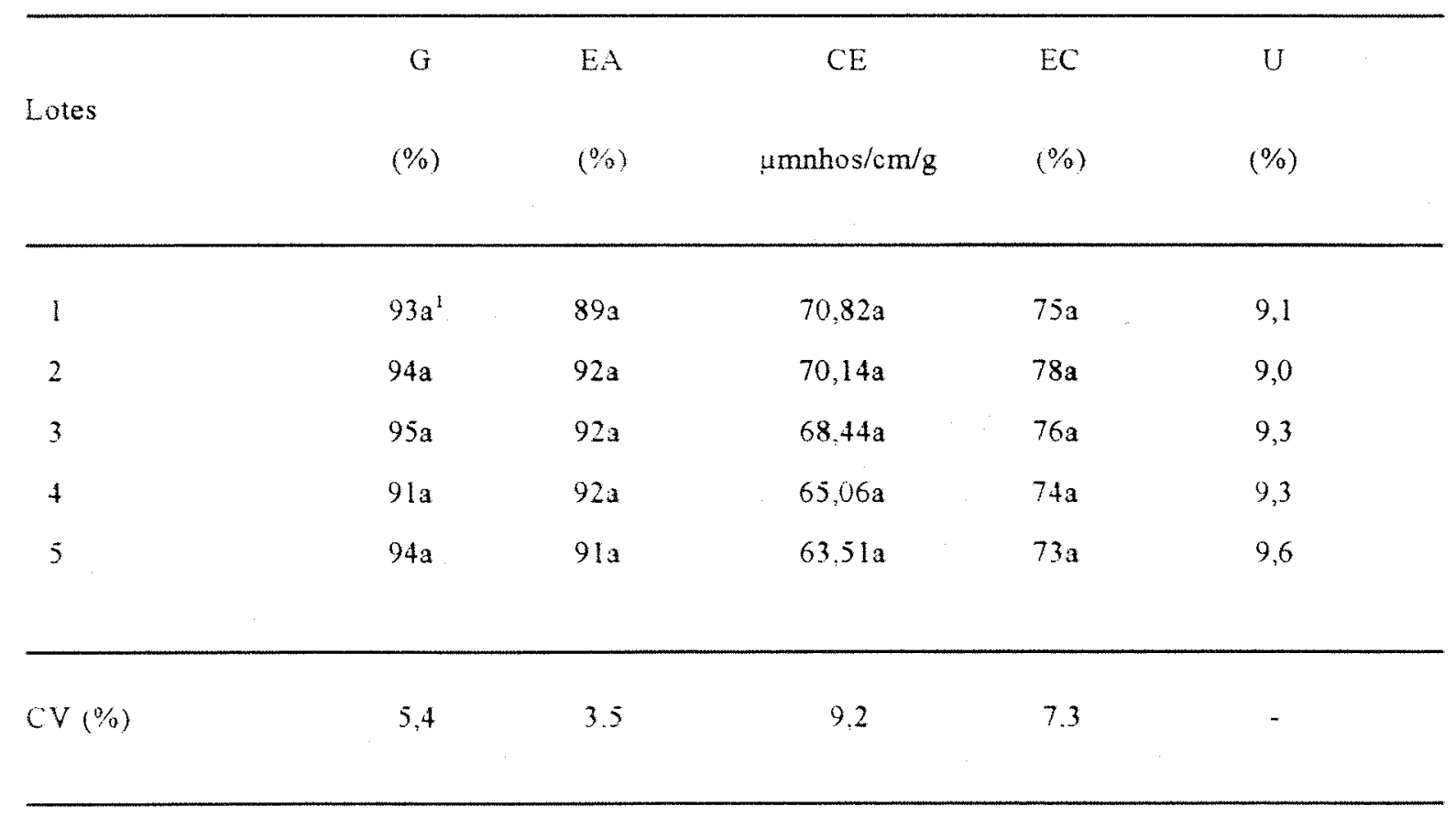

${ }^{1}$ Médias seguidas por letras distintas diferem entre si ao nivel de $5 \%$ de significância. 


\subsubsection{Considerações gerais}

De acordo com o que foi exposto para cada cultivar analisado, e tendo em vista a escolha de cultivares para realização de estudos posteriores, quando é interessante a diferença de qualidade entre os lotes, optou-se pelo cultivar BR 38, onde as diferenças entre os lotes foram verificadas em todos os testes.

Quanto ao outro cultivar, a escolha ficou mais dificil pois não havia uma diferença clara entre os lotes dos outros três cultivares. Assim, optou-se pelo IAC 15 porque seria interessante a verificação da sensibilidade do teste de lixiviação de potássio quando as diferenças de vigor são pouco evidentes. Os lotes dos outros cultivares apresentaram-se muito homogêneos entre si, principalmente os lotes do cultivar IAS 5 (Tabela 9), em todos os testes, e, os lotes do cultivar BR 36, no teste de emergência das plântulas em campo, o que não foi considerado conveniente para os objetivos do experimento III (estudo do teste de lixiviação de potássio).

O monitoramento da umidade das sementes por ocasião de realização dos testes é muito importante como tem sido ressaltado por diversos autores, entre eles, mais recentemente MARCOS FILHO et al (1987), LOEFFLER et al. (1988), KRZYZANOWSKI et al. (1991), VIEIRA (1994) e MARCOS FILHO (1994a), que recomendam certa uniformidade do grau de umidade entre os lotes que serăo comparados, pois essas diferenças podem interferir nos resultados dos testes, levando à erros. A recomendação está entre 11 e $17 \%$ para o teste de condutividade elétrica e entre 11 e $15 \%$ para o teste de envelhecimento acelerado. Ultimamente, no entanto, recomenda-se monitorar

o grau de umidade das sementes após o envelhecimento para averiguar se o teste precisa ser refeito (KRZYZANOWSKI et al, 1991; MARCOS FILHO, 1994a). No presente 
trabalho, o monitoramento dos cinco lotes para cada um dos quatro cultivares mostrou que as sementes atingem, após $48 \mathrm{~h}$ a $41^{\circ} \mathrm{C}$, teores de água entre 20 a $24 \%$. Segundo KRZYZANOWSKI et al. (1991), sob o mesmo período e temperatura, a umidade atingida foi de 27 a $30 \%$, porém, não há citação a respeito do grau de umidade inicial das sementes.

\subsection{Experimento II}

\subsubsection{Estudo das curvas de calibração do fotômetro de chama}

Nas Figuras 1, 2, 3 e 4 estão as representações gráficas das regressões lineares obtidas com a calibração do fotòmetro de chama, respectivamente, com padrão 20 ppm de potássio e leitura 50 , padrão $30 \mathrm{ppm}$ de potássio e leitura 50 , padrão $40 \mathrm{ppm}$ de potássio e leitura 100 e finalmente, padrão $50 \mathrm{ppm}$ de potássio e leitura 100 . 


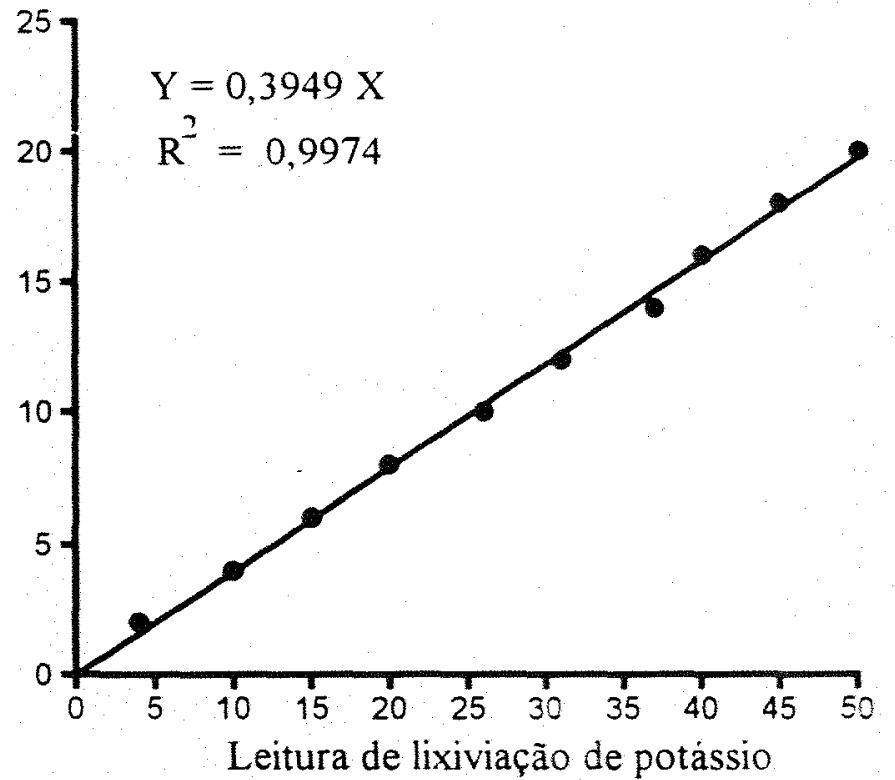

- Regressão Linear • Otsenaçōes

Figura 1. Representação gráfica da curva 1 de calibração do fotómetro de chama.

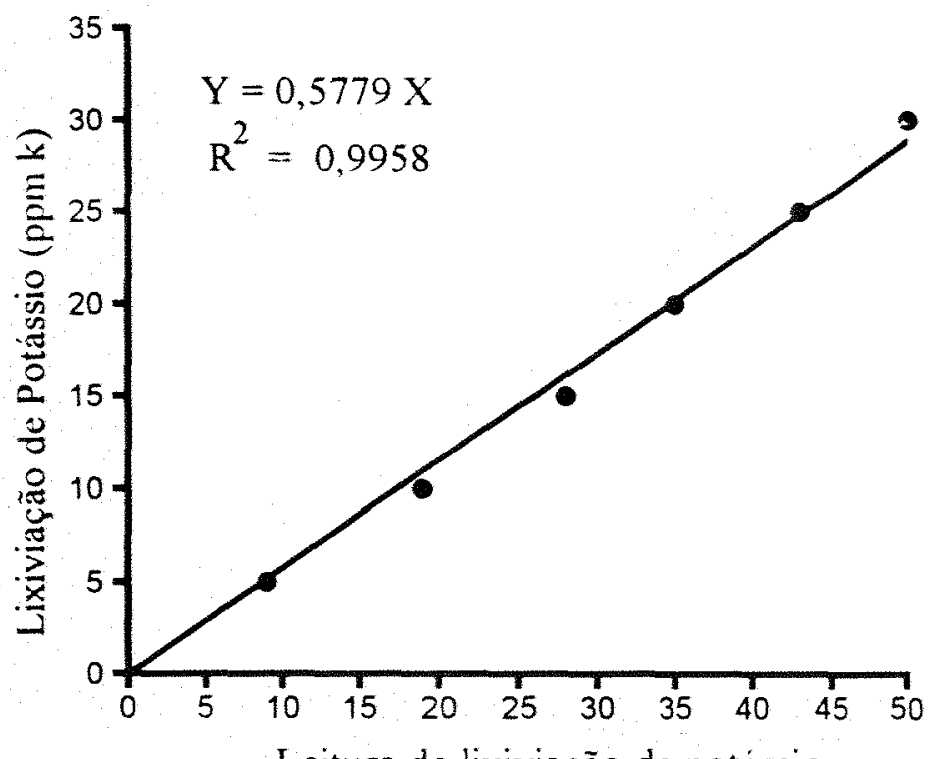

Leitura de lixiviação de potássio

- Regressão Linear - Observaçōes

Figura 2. Representação gráfica da curva 2 de calibração do fotômetro de chama.

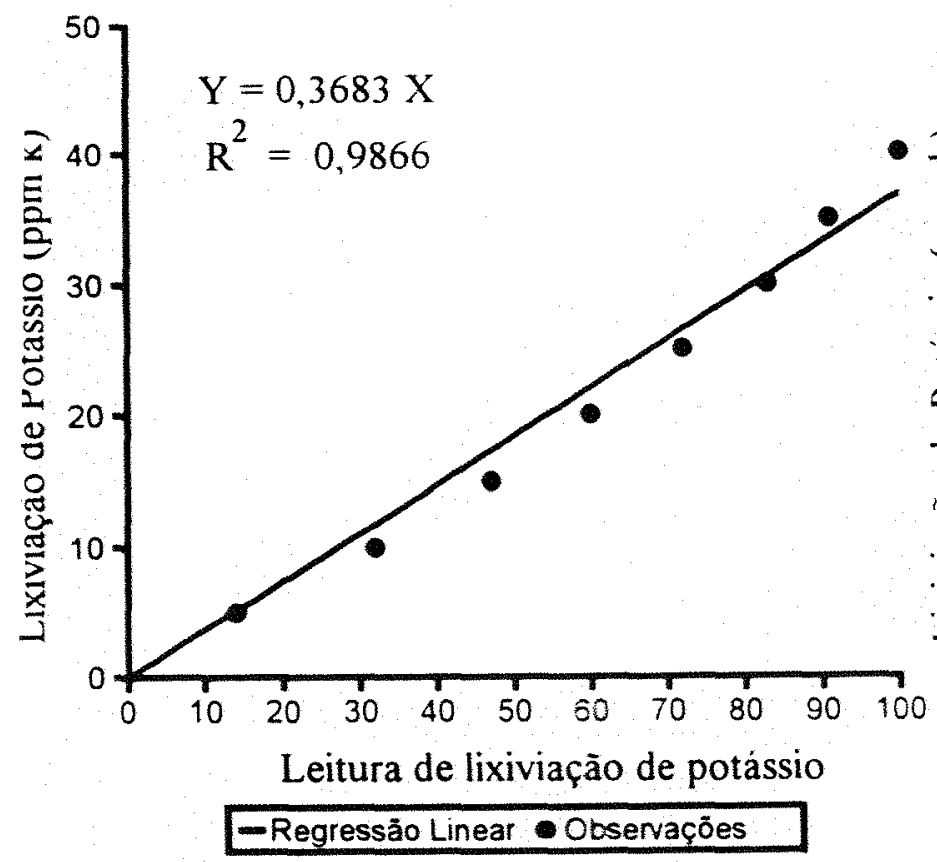

Figura 3. Representação gráfica da curva 3 de calibração do fotômetro de chama

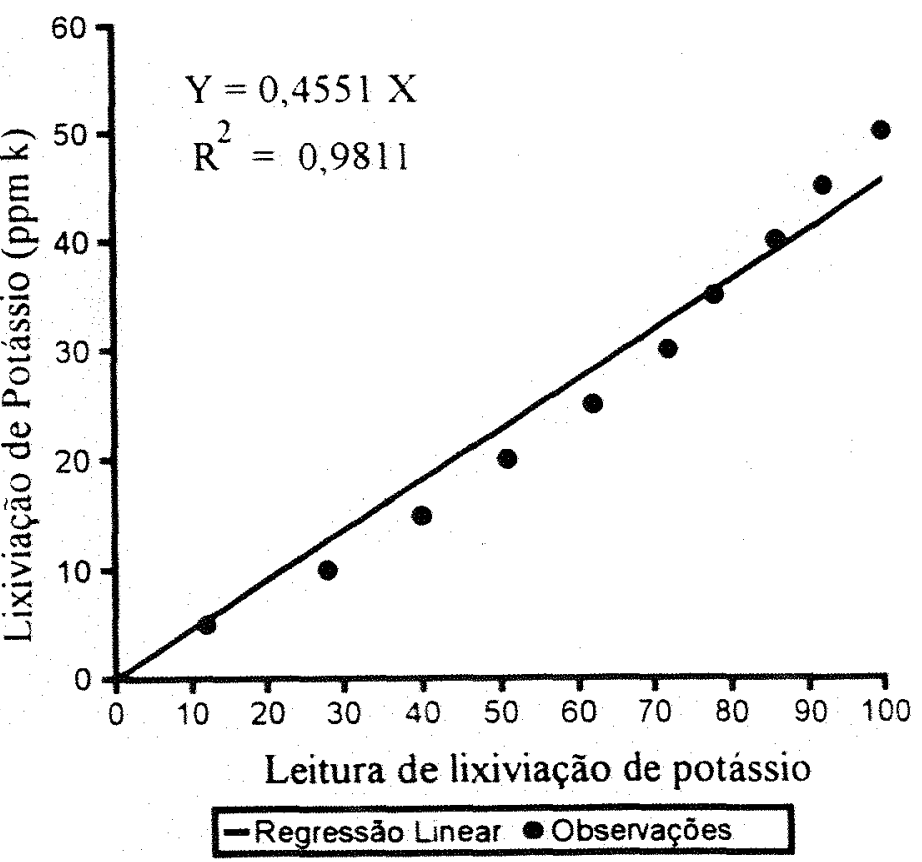

Figura 4. Representação gráfica da curva 4 de calibração do fotômetro de chama. 
Verificou-se que todos os padrões estudados apresentaram linearidade com altos coeficientes de determinacão $\left(R^{2}\right)$. O coeficiente de determinação mais elevado foi obtido com a curva 1, ou seja, calibração 20 ppm de potássio e leitura $50(0,9974)$ e, o menor, fol obtido com a curva 4, ou seja, calibração 50 ppm de potássio e leitura 100 $(0,9811)$, respectivamente, nas Figuras 1 e 4.

Analisando-se os valores de F (Tabela 10), obtidos nas análises da variância dos dados referentes à lixiviação de potássio para os lotes dos cultivares BR 38 e IAC 15 através das quatro curvas de calibração, verificou-se que os lotes do cultivar BR 38 apresentaram diferenças altamente significativas de lixiviação de potássio para todas as curvas estudadas. Comparando-se com os resultados de lixiviação de potássio para cada lote e curva estudada (Tabela 11), verificou-se que houve uma semelhança de classificação em níveis de vigor entre as curvas, mesmo havendo diferenças em valores absolutos. Vale observar, também, que a classificação dos lotes foi semelhante àquela obtida com os outros testes de avaliação da qualidade fisiológica feitos com os lotes do cultivar BR 38 durante o experimento I (Tabela 6), o que confirmou a adequação das curvas para determinação do potássio lixiviado de sementes de soja, através do teste proposto, quando o objetivo foi verificar a qualidade fisiológica dos mesmos. 
Tabela 10. Valores de $\mathrm{F}$ obtidos nas análises da variância dos dados referentes a lixiviação de potássio através de quatro curvas de calibração para os lotes dos cultivares BR 38 e IAC 15 durante o experimento II. Piracicaba, 1993.

Condição teste

\section{Cultivares}

IAC 15
BR 38

$14,7952 * *$

$24,3811 * *$

$27,4549 * *$

$28,2791^{* *}$

\section{BR 38}

Curva 1

Curva 2

Curva 3

Curva 4
-

* Significativo ao nível de $1 \%$ de probabilidade.

$\therefore$ Não significativo.

Tabela 11. Média dos resultados de lixiviação de potássio obtidos através de quatro curvas de calibração para o cultivar BR 38 durante o experimento II. Piracicaba, 1993.
$1,2154^{\mathrm{NS}}$

$0,4514^{\mathrm{vs}}$

$0,3593^{\text {is }}$

$0,3917^{\text {is }}$
Curva 2

Curva 3

Lotes

ppm K/g semente

\begin{tabular}{lllll}
\hline & & & & \\
1 & $451 \mathrm{bc}$ & $430 \mathrm{~b}$ & $470 \mathrm{bc}$ & $504 \mathrm{bc}$ \\
2 & $386 \mathrm{~b}$ & $411 \mathrm{~b}$ & $442 \mathrm{~b}$ & $472 \mathrm{~b}$ \\
3 & $491 \mathrm{bc}$ & $460 \mathrm{bc}$ & $495 \mathrm{bc}$ & $530 \mathrm{bc}$ \\
4 & $244 \mathrm{a}$ & $266 \mathrm{a}$ & $277 \mathrm{a}$ & $303 \mathrm{a}$ \\
5 & $524 \mathrm{c}$ & $508 \mathrm{c}$ & $544 \mathrm{c}$ & $583 \mathrm{c}$ \\
\hline $\mathrm{CV}(\%)$ & 12,2 & 7,9 & 7,7 & 7,4 \\
\hline
\end{tabular}


Verificando os coeficientes de variação $(\mathrm{CV})$, notaram-se valores mais altos nos resultados da curva 1, o que pôde ser explicado devido a necessidade de diluição de todas as amostras submetidas à leitura. Essa necessidade de diluição foi muito desfavorável ao teste, pois aumenta a possibilidade de variações, devido a tomada de alíquotas de pequeno volume, e aumenta o tempo requerido para a realização do teste. A curva 4 foi aquela que apresentou o menor coeficiente de variação, e onde não foi necessário fazer diluição das amostras, além de ter fornecido resultados relacionados com as outras curvas e com os demais testes de qualidade fisiológica em termos de classificação dos lotes em níveis de vigor (Tabelas 6 e 11 ).

Analisando-se os valores de F (Tabela 10), obtidos nas análises da variância dos dados referentes à lixiviaçăo de potássio para os lotes dos cultivares BR 38 e IAC 15 através das quatro curvas de calibração, verificou-se que os lotes do cultivar IAC 15 não apresentaram diferenças estatísticas significativas em nenhuma das curvas. Comparando-se com os resultados de lixiviação de potássio para cada lote e curva estudada (Tabela 12), verificou-se que há uma grande proximidade de resultados, pois em nenhuma das curvas houve diferenças estatísticas entre os lotes, o que também foi observado com os outros testes para avaliação da qualidade físiológica realizados com os lotes do cultivar IAC 15 durante o experimento I (Tabela 8). 
Tabela 12. Média dos resultados de lixiviação de potássio obtidos através de quatro curvas de calibração para o cultivar IAC 15 durante o experimento II. Piracicaba, 1993

\begin{tabular}{lcccc} 
& Curva 1 & Curva 2 & Curva 3 & Curva 4 \\
Lotes & \multicolumn{5}{c}{ ppm K/g semente } \\
\cline { 2 - 5 } & & & \\
\hline & $645 \mathrm{a}$ & $619 \mathrm{a}$ & $666 \mathrm{a}$ & $708 \mathrm{a}$ \\
2 & $748 \mathrm{a}$ & $624 \mathrm{a}$ & $667 \mathrm{a}$ & $708 \mathrm{a}$ \\
3 & $788 \mathrm{a}$ & $664 \mathrm{a}$ & $705 \mathrm{a}$ & $752 \mathrm{a}$ \\
5 & $662 \mathrm{a}$ & $621 \mathrm{a}$ & $660 \mathrm{a}$ & $704 \mathrm{a}$ \\
& $698 \mathrm{a}$ & $623 \mathrm{a}$ & $667 \mathrm{a}$ & $713 \mathrm{a}$ \\
\hline & & & 9,0 & 8,9 \\
\hline
\end{tabular}

Da mesma forma como foi discutido para o cultivar BR 38, também quando se observaram os valores do coeficiente de variação (CV) das quatro curvas para o cultivar IAC 15, notou-se que a curva 1 também apresentou valor mais al to que as demais, em função da necessidade de diluição das amostras. Assim, conforme recomenda RODELA \& BORGES (1989), se forem obtidas relaçōes lineares para várias curvas de calibração, como no presente caso, onde o coeficiente de determinação mais baixo foi o da curva 4 , com 0,9811 , que é um valor muito bom, será escolhida a curva ajustada com o padrão de maior concentração, pois quanto mais diluído o padrão de ajuste, maiores serão 
as diluições a serem feitas nas amostras, o que, no caso de um teste de laboratório, que tem como vantagem adicional a rapidez e praticidade, o inviabilizaria.

\subsubsection{Considerações gerais}

Diante do exposto, a curva de calibração que melhor atendeu aos objetivos do teste de lixiviação de potássio com sementes de soja foi a curva 4 (padrão 50 ppm de potássio para leitura 100), pois apesar do menor coeficiente de determinação, apresentou alta linearidade e respostas similares à curva 1. Como vantagem adicional, permitiu leitura de todas as amostras, sem a necessidade de diluição, o que tornou a leitura rápida e, devido a não interferência das diluições, permitiu menores coeficientes de variação.

\subsection{Experimento III}

\subsubsection{Determinações complementares}

\subsubsection{Peso de 1000 sementes}

O peso de 1000 sementes (Tabela 13) avaliado de acordo com as Regras para Análise de Sementes (BRASIL, 1992), indicou que praticamente não ocorreram 
diferenças de peso entre os lotes de um mesmo cultivar; porém notaram-se diferenças entre cultivares, sendo que o cultivar BR 38 apresentou sementes mais pesadas que as do cultivar IAC 15. SMION \& MATHAVAN (1986) e QUEIROGA \& PARRA (1989) ressaltaram a influència do peso da semente na lixiviação de potassio, mostrando que as mais pesadas liberam maiores quantidades. Como não ocorreram diferenças de peso entre os lotes, as diferenças de lixiviação de potássio entre lotes do mesmo cultivar, não foram atribuídas a diferenças no tamanho (peso) das sementes.

Tabela 13. Peso de 1000 sementes dos cinco lotes dos cultivares BR 38 e IAC 15, durante o experimento III. Piracicaba, 1993.

\begin{tabular}{|c|c|c|c|c|c|c|c|c|c|c|}
\hline \multirow{2}{*}{ Cultivar/Lote } & \multicolumn{5}{|c|}{ BR 38} & \multicolumn{5}{|c|}{ IAC 15} \\
\hline & 1 & 2 & 3 & 4 & 5 & 1 & 2 & 3 & 4 & 5 \\
\hline $\begin{array}{l}\text { Peso de } 1000 \\
\text { sementes }(\mathrm{g})\end{array}$ & 171,0 & 168,4 & 163,1 & 171,8 & 172.4 & 128.3 & 130,3 & 129,8 & 129,3 & 131,2 \\
\hline
\end{tabular}




\subsubsection{Análise da composição química das sementes}

A análise da composição química dos lotes foi feita com o intuito de venficar se os resultados da lixiviação de potássio ou de condutividade elétrica poderiam ser influenciadas pela concentração de ions nas sementes. Esta observação pode oferecer major segurança para a interpretação dos resultados obtidos em testes de liberação de exsudatos, pois é desejável que as sementes avaliadas não apresentem variações acentuadas nas concentrações de íons e, mais especificamente no presente trabalho, na de potássio. Analisando-se as Tabelas 14 e 15 verifica-se que os valores de potássio pouco variaram, quer entre lotes de um mesmo cultivar, quer entre cultivares, o que parece indicar que as respostas das sementes aos testes de lixiviação de potássio e de condutividade elétrica não devem ser atribuidas a diferenças na concentração de ions dos diferentes lotes.

Tabela 14. Resultados da análise da composição química das sementes dos cinco lotes do cultivar BR 38 em termos de macronutrientes e micronutrientes, durante o experimento III Piracicaba, 1993

\begin{tabular}{|c|c|c|c|c|c|c|c|c|c|c|c|c|}
\hline \multirow{2}{*}{ Lotes } & $\mathrm{N}$ & $\mathrm{P}$ & $\mathrm{K}$ & $\mathrm{Ca}$ & $\mathrm{Mg}$ & $\mathrm{S}$ & $B$ & $\mathrm{Cu}$ & $\mathrm{Fe}$ & $\mathrm{Mg}$ & Mo & $\mathrm{Zn}$ \\
\hline & \multicolumn{6}{|c|}{$\%$} & \multicolumn{6}{|c|}{ ppm } \\
\hline 1 & 6,02 & 0,50 & 1,68 & 0,17 & 0,19 & 0,16 & 33 & 10 & 52 & 20 & - & 31 \\
\hline 2 & 6,05 & 0,46 & 1,76 & 0,17 & 0,20 & 0,20 & 30 & 8 & 74 & 21 & - & 36 \\
\hline 3 & 5,96 & 0,57 & 1,53 & 0,15 & 0,21 & 0,21 & 30 & 10 & 100 & 19 & - & 38 \\
\hline 4 & 6,26 & 0,39 & 1,61 & 0,16 & 0,18 & 0,18 & 32 & 8 & 104 & 20 & - & 39 \\
\hline 5 & 5,92 & 0,52 & 1,76 & 0,18 & 0,22 & 0,17 & 22 & 10 & 101 & 21 & - & 37 \\
\hline
\end{tabular}


Tabela 15. Resultados da análise da composição química das sementes dos cinco lotes do cultivar IAC 15 em termos de macronutrientes e micronutrientes, durante o experimento III. Piracicaba, 1993.

\begin{tabular}{|c|c|c|c|c|c|c|c|c|c|c|c|c|}
\hline \multirow{2}{*}{ Lotes } & $\mathrm{N}$ & $\mathrm{P}$ & $\mathrm{K}$ & $\mathrm{Ca}$ & $\mathrm{Mg}$ & $S$ & $\mathrm{~B}$ & $\mathrm{Cu}$ & $\mathrm{Fe}$ & $\mathrm{Mg}$ & Mo & $\mathrm{Zn}$ \\
\hline & \multicolumn{6}{|c|}{$\%$} & \multicolumn{6}{|c|}{ ppm } \\
\hline 1 & 6,27 & 0,30 & 1,30 & 0,14 & 0,17 & 0,17 & 27 & 7 & 58 & 20 & - & 30 \\
\hline 2 & 5,61 & 0,40 & 1,84 & 0,19 & 0,18 & 0,15 & 24 & 7 & 48 & 24 & - & 27 \\
\hline 3 & 6,34 & 0,36 & 1,45 & 0,18 & 0,16 & 0,17 & 25 & 8 & 46 & 22 & - & 27 \\
\hline 4 & 6,61 & 0,39 & 1,84 & 0,18 & 0,18 & 0,17 & 23 & 7 & 42 & 24 & - & 29 \\
\hline 5 & 6,47 & 0,34 & 1,91 & 0,18 & 0.19 & 0,15 & 22 & 7 & 41 & 21 & - & 29 \\
\hline
\end{tabular}

\subsubsection{Teste de sanidade}

O teste de sanidade realizado com os lotes dos cultivares BR 38 e IAC 15 (Tabela 16) demonstrou que nos lotes do cultivar IAC 15 havia menor incidência de fungos que nos lotes do cultivar BR 38, porém para nenhum patógeno foi verificada presença em mais de $10 \%$ das sementes. O fungo Fusarium sp. foi detectado em $9 \%$ das sementes do lote 3 do cultivar BR 38; por outro lado, este fungo praticamente não foi encontrado nos lotes do cultivar IAC 15. Outro fungo encontrado nos lotes do cultivar BR 38 foi A spergillus sp. que estava em $7 \%$ das sementes do lote 5 e em $6 \%$ das sementes do lote 2. 
Tabela 16. Resultados do teste de sanidade realizado com os cinco lotes dos cultivares BR 38 e IAC 15 durante o experimento III. Piracicaba, 1993.

\begin{tabular}{|c|c|c|c|c|c|c|}
\hline \multirow[b]{2}{*}{ Cultivar } & \multirow[b]{2}{*}{ Lote } & \multicolumn{5}{|c|}{ Microrganismo } \\
\hline & & $\begin{array}{c}\text { Phomopsis } \\
\text { sp. }\end{array}$ & $\begin{array}{l}\text { A spergillus } \\
\mathrm{sp} \text {. }\end{array}$ & $\begin{array}{c}\text { Penicillum } \\
\text { sp. }\end{array}$ & $\begin{array}{c}\text { Fusarium } \\
\mathrm{sp} .\end{array}$ & $\begin{array}{l}\text { Cercospora } \\
\text { sojina }\end{array}$ \\
\hline & & \multicolumn{5}{|c|}{$\%$ sementes infestadas } \\
\hline \multirow{5}{*}{ BR 38} & 1 & 2 & 2 & 3 & 4 & ${ }^{1}$ \\
\hline & 2 & 2 & 6 & 1 & 4 & - \\
\hline & 3 & - & 1 & 1 & 9 & 4 \\
\hline & 4 & 1 & 4 & 2 & 1 & 4 \\
\hline & 5 & - & 7 & 3 & 3 & 1 \\
\hline \multirow[t]{5}{*}{ IAC 15} & 1 & 2 & 1 & 1 & 1 & - \\
\hline & 2 & 1 & - & 1 & - & - \\
\hline & 3 & 1 & - & - & - & - \\
\hline & 4 & 1 & 2 & 2 & - & - \\
\hline & 5 & 2 & 2 & - & - & - \\
\hline
\end{tabular}

${ }^{1}$ Não foi detectada a presença do fungo.

Embora o teste de sanidade tenha revelado a presença de estruturas de patógenos nas sementes, não foi encontrada presença de nenhum deles, de maneira que pudessem interferir nos resultados dos testes de verificação da qualidade fisiológica dos lotes e no estudo da lixiviação de potássio.

\subsubsection{Dados de temperatura e umidade relativa do ambiente de armazenamento}

O levantamento dos dados de temperatura e umidade relativa do ambiente de armazenamento (Tabela 17) mostrou que foi possível obter condições adequadas de temperatura e umidade relativa do ar durante o período experimental. Segundo MARCOS FILHO et al. (1986), as sementes de soja, ricas em óleo e proteínas, conservam-se melhor sob condições de temperatura amena e umidade relativa do ar inferior a $70 \%$, de modo que se mantenham com grau de umidade inferior a $12,0 \%$. 
Tabela 17. Média dos dados de temperatura e umidade relativa do ar no ambiente de armazenamento durante todo o período experimental. Piracicaba, 1993

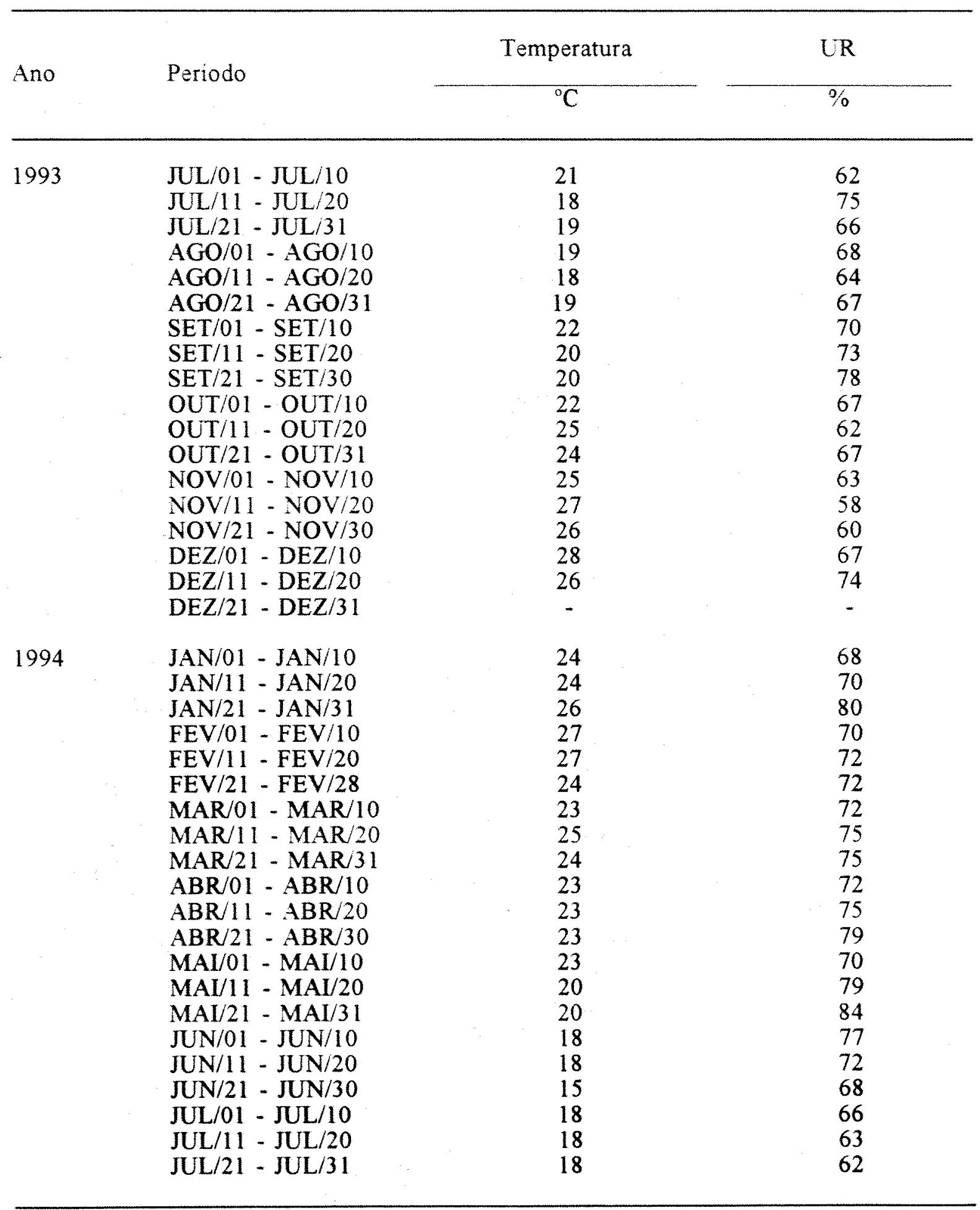




\subsubsection{Teste de Lixiviação de Potássio}

\subsubsection{Cultivar BR 38}

Os valores de F obtidos nas análises da variância dos dados referentes ao teste de lixiviação de potássio para o cultivar BR 38 (Tabela 18), indicaram que ocorreu efeito significativo para tratamentos e lotes nas duas temperaturas de embebição estudadas e em todas as épocas, ao contrário da interação tratamentos $x$ lotes, que năo foi significativa, indicando que os tratamentos não interferiram na classificação dos lotes, dentro de cada temperatura.

Tabela 18. Valores de F obtidos nas análises da variancia dos dados referentes ao teste de lixiviação de potássio para o cultivar BR 38, durante o experimento III. Piracicaba, 1994.

\begin{tabular}{lllll}
\hline & & & \\
& & & \\
Temperatura/Época & & Tratamentos $(\mathrm{T})$ & Lotes $(\mathrm{L})$ & Interação $(\mathrm{TxL})$ \\
\cline { 3 - 5 } & & & & \\
\hline & & & & \\
$25^{\circ} \mathrm{C}$ & $\mathrm{E}_{3}$ & $36,9023^{* *}$ & $61,5540^{* *}$ & $1,4660^{\mathrm{NS}}$ \\
& $\mathrm{E}_{2}$ & $85,4508^{* *}$ & $49,8586^{* *}$ & $1,1824^{\mathrm{NS}}$ \\
& $\mathrm{E}_{3}$ & $63,5711^{* *}$ & $61,5772^{* *}$ & $1,3175^{\mathrm{NS}}$ \\
$30^{\circ} \mathrm{C}$ & $\mathrm{E}_{1}$ & $77,8737^{* *}$ & $56,0059^{* *}$ & $1,0885^{\mathrm{NS}}$ \\
& $\mathrm{E}_{2}$ & $25,4627^{* *}$ & $38,3099^{* *}$ & $1,1278^{\mathrm{NS}}$ \\
& $\mathrm{E}_{3}$ & $45,4709^{* *}$ & $33,2385^{* *}$ & $0,9072^{\mathrm{NS}}$ \\
\hline
\end{tabular}

** Significativo ao nível de $1 \%$ de probabilidade.

NS Não significativo. 


\subsection{Testes de lixiviação de potássio realizados a $25^{\circ} \mathrm{C}$}

As Tabelas 19, 20 e 21 mostram os resultados de lixiviação de potássio obtidos respectivamente, durante as épocas 1,2 e 3 , quando a embebição das sementes foi efetuada a $25^{\circ} \mathrm{C}$. Os tratamentos diferiram entre si; porém, não houve interferència destes na classificação dos lotes em termos de qualidade físiológica.

Os resultados das três épocas (Tabelas 19, 20 e 21) mostraram que, em geral, as quantidades de potássio lixiviado foram proporcionais ao período de embebição e à quantidade de água utilizada.

Tabela 19. Médias dos resultados de lixiviação de potássio para o cultivar BR 38 conduzida à temperatura de $25^{\circ} \mathrm{C}$ durante a primeira época do experimento III. Piracicaba, 1993.

\begin{tabular}{|c|c|c|c|c|c|c|}
\hline \multirow{3}{*}{ Tratamento } & \multicolumn{5}{|c|}{ Lote } & \multirow{3}{*}{ Média } \\
\hline & 1 & 2 & 3 & 4 & 5 & \\
\hline & \multicolumn{5}{|c|}{ ppm $\mathrm{K} / \mathrm{g}$ semente } & \\
\hline $75 \mathrm{ml} / 30 \mathrm{~min}$ & 492 & 384 & 557 & 420 & 599 & $490 \mathrm{~A}^{\mathrm{l}}$ \\
\hline $75 \mathrm{ml} 60 \mathrm{~min}$ & 574 & 544 & 640 & 375 & 627 & $552 \mathrm{BC}$ \\
\hline $75 \mathrm{~mL} 90 \mathrm{~min}$ & 628 & 576 & 698 & 441 & 676 & $604 \mathrm{CD}$ \\
\hline $100 \mathrm{ml} / 30 \mathrm{~min}$ & 484 & 476 & 596 & 358 & 601 & $503 \mathrm{AB}$ \\
\hline $100 \mathrm{ml} / 60 \mathrm{~min}$ & 590 & 597 & 783 & 556 & 755 & $656 \mathrm{DE}$ \\
\hline $100 \mathrm{ml} 90 \mathrm{~min}$ & 677 & 671 & 775 & 547 & 731 & $680 \mathrm{E}$ \\
\hline Média & $574 b^{l}$ & $541 \mathrm{~b}$ & $675 \mathrm{c}$ & $450 a$ & $665 \mathrm{c}$ & 581 \\
\hline
\end{tabular}

${ }^{1}$ Médias seguidas por letras distintas diferem entre si ao nivel de $5 \%$ de significância. 
Dentro de uma mesma quantidade de água, quanto maior o período de embebição maior a quantidade de potássio lixiviado para as três épocas. SIMON \& MATHAVAN (1986), trabalhando com diferentes espécies concluiu que um grupo de espécies, entre elas ervilha, feijão e girassol, absorvem água e lixiviam solutos por um período que se estende por várias horas. Um segundo grupo de sementes, no qual são incluidas várias umbeliferas, completam ambas, absorção de água e lixiviação, em uma hora ou até em menos tempo. Os resultados obtidos neste trabalho indicam que a soja se enquadra no grupo onde a lixiviação se estende por mais tempo.

Dentro de 30 minutos de embebição, para todas as épocas, não ocorreram diferenças significativas na quantidade de potássio lixiviada entre 75 a $100 \mathrm{ml}$ de água. Quando se trabalhou com 60 minutos, ocorreram acréscimos significativos da lixiviação de potássio com o uso de $100 \mathrm{ml}$ de água, em relação a $75 \mathrm{ml}$, somente para a primeira época enquanto que, quando se utilizou o período de 90 minutos, tal fato ocorreu apenas na primeira e segunda épocas. Portanto, os tratamentos 1 ( $75 \mathrm{ml} / 30 \mathrm{~min})$ e 4 (100 $\mathrm{ml} / 30 \mathrm{~min}$ ), por serem os tratamentos que propiciaram menores níveis de lixiviação de potássio, poderiam ser considerados mais adequados à leitura em fotômetro de chama. A observação da menor lixiviação de potássio pelos tratamentos 1 e 4 pode ser também constatada pela análise das Tabelas 20 e 21 , para as épocas 2 e 3, respectivamente.

O uso de 90 minutos, ou seja, o maior período de embebição, provocou acentuado aumento na lixiviação de potássio, principalmente quando acompanhado do uso de $100 \mathrm{ml}$ de água, indicando que esta combinação (tratamento 6) foi 
desfavorável, dificultando as leituras no fotômetro de chama e aumentando a probabilidade de serem necessárias diluições nas amostras, o que torna o teste pouco prático para uso rotineiro, como foi mostrado no experimento II

Tabela 20. Médias dos resultados de lixiviação de potássio para o cultivar BR 38 conduzida à temperatura de $25^{\circ} \mathrm{C}$, durante a segunda época do experimento III. Piracicaba, 1994.

\begin{tabular}{|c|c|c|c|c|c|c|}
\hline \multirow{3}{*}{ Tratamento } & \multicolumn{5}{|c|}{ Lote } & \multirow{3}{*}{ Média } \\
\hline & 1 & 2 & 3 & 4 & 5 & \\
\hline & \multicolumn{5}{|c|}{ ppm $\mathrm{K} / \mathrm{g}$ semente } & \\
\hline $75 \mathrm{ml} / 30 \mathrm{~min}$ & 477 & 415 & 470 & 369 & 573 & $461 \mathrm{~A}^{1}$ \\
\hline $75 \mathrm{ml} / 60 \mathrm{~min}$ & 614 & 515 & 666 & 450 & 630 & $575 \mathrm{~B}$ \\
\hline $75 \mathrm{ml} / 90 \mathrm{~min}$ & 568 & 559 & 681 & 500 & 680 & $598 \mathrm{~B}$ \\
\hline $100 \mathrm{ml} / 30 \mathrm{~min}$ & 520 & 462 & 564 & 348 & 574 & $493 \mathrm{~A}$ \\
\hline $100 \mathrm{ml} / 60 \mathrm{~min}$ & 595 & 606 & 681 & 517 & 645 & $609 \mathrm{~B}$ \\
\hline $100 \mathrm{ml} / 90 \mathrm{~min}$ & 774 & 760 & 884 & 639 & 896 & $791 \mathrm{C}$ \\
\hline Média & $591 b^{1}$ & $553 \mathrm{~b}$ & $658 \mathrm{c}$ & $470 a$ & $666 \mathrm{c}$ & 588 \\
\hline
\end{tabular}

${ }^{1}$ Médias seguidas por letras distintas diferem entre si ao nível de $5 \%$ de significância. 
Quanto a diferenciação dos lotes em níveis de vigor, percebeu-se que há concordância entre as très épocas ao indicar os lotes 3 e 5 como tendo qualidade fisiológica inferior aos demais e também em apontar o lote 4 como o de melhor qualidade. O lote 2 apresentou tendència de ser um bom lote, como foi verificado na primeira e terceira épocas.

Estes resultados são concordantes com os resultados da avaliação preliminar - experimento I (Tabela 6) que também apontaram o lote 3 seguido do lote 5 como os piores lotes, enquanto o lote 4 se sobressaiu principalmente nos testes de germinação, condutividade elétrica e emergência das plântulas em campo.

Tabela 21. Médias dos resultados de lixiviação de potássio para o cultivar BR 38 conduzida a temperatura de $25^{\circ} \mathrm{C}$, durante a terceira época do experimento III. Piracicaba, 1994.

\begin{tabular}{|c|c|c|c|c|c|c|}
\hline \multirow{3}{*}{ Tratamento } & \multicolumn{5}{|c|}{ Lote } & \multirow{3}{*}{ Média } \\
\hline & 1 & 2 & 3 & 4 & 5 & \\
\hline & \multicolumn{5}{|c|}{ ppm K/g semente } & \\
\hline $75 \mathrm{ml} / 30 \mathrm{~min}$ & 440 & 419 & 578 & 373 & 575 & $477 \mathrm{~A}^{1}$ \\
\hline $75 \mathrm{ml} / 60 \mathrm{~min}$ & 556 & 527 & 634 & 513 & 670 & $580 \mathrm{~B}$ \\
\hline $75 \mathrm{ml} / 90 \mathrm{~min}$ & 680 & 666 & 767 & 541 & 715 & $674 \mathrm{C}$ \\
\hline $100 \mathrm{ml} / 30 \mathrm{~min}$ & 415 & 363 & 597 & 360 & 575 & $462 \mathrm{~A}$ \\
\hline $100 \mathrm{ml} / 60 \mathrm{~min}$ & 519 & 507 & 619 & 436 & 660 & $548 \mathrm{~B}$ \\
\hline $100 \mathrm{ml} / 90 \mathrm{~min}$ & 645 & 605 & 781 & 637 & 822 & $698 \mathrm{C}$ \\
\hline Média & $542 b^{\prime}$ & $514 a b$ & $663 c$ & $477 a$ & $669 c$ & 573 \\
\hline
\end{tabular}

${ }^{1}$ Médias seguidas de letras distintas diferem entre si ao nível de $5 \%$ de significància. 


\subsection{Testes de lixiviação de potássio realizados a $30^{\circ} \mathrm{C}$}

De forma geral, os valores da lixiviação de potássio realizada a $30^{\circ} \mathrm{C}$ foram mais elevados que aos obtidos quando se trabalhou com $25^{\circ} \mathrm{C}$. Isto pode ser verificado comparando-se as médias gerais das Tabelas 19,20 e $21\left(25^{\circ} \mathrm{C}\right) \mathrm{com}$ as médias das Tabelas 22,23 e $24\left(30^{\circ} \mathrm{C}\right)$. Tal fato indicou que a lixiviação de potássio tende a aumentar com a elevação da temperatura. MURPHY \& NOLAND (1982) ressaltam que o efeito da temperatura sobre a embebição e lixiviação pode estar relacionado com alterações na viscosidade da água, interferindo tanto na quantidade como na velocidade de liberação dos exsudatos.

As Tabelas 22, 23 e 24 representam a lixiviação de potássio, respectivamente para as épocas 1,2 e 3, para o cultivar BR 38, quando se procedeu a lixiviação a $30^{\circ} \mathrm{C}$.

Os tratamentos diferiram entre si quanto à quantidade de potássio lixiviada, mas não houve interferência dos tratamentos na classificação dos lotes, como pode ser observado através do teste F (Tabela 18) pela não significância da interação tratamentos $\times$ lotes

Assim, como foi observado para $25^{\circ} \mathrm{C}$ de embebição, a $30^{\circ} \mathrm{C}$ notou-se que para uma mesma quantidade de água, quanto maior o tempo de embebição, maiores são as quantidades de potássio lixiviadas das sementes. Este fato foi constatado para as três épocas de realização do teste.

Quando se consideraram os períodos de embebição, para 30 minutos ocorreram diferenças entre a quantidade de potássio lixiviada a $75 \mathrm{ml}$ e a $100 \mathrm{ml}$ de água, 
sendo que, a $75 \mathrm{ml}$ a quantidade de potassio foi maior na primeira época. Nas outras épocas não houveram diferenças. A 60 minutos so ocorreram diferenças significativas na quantidade de potássio lixiviada na segunda época, quando $100 \mathrm{ml}$ provocou maior lixiviação que $75 \mathrm{ml}$

A 90 minutos ocorreram diferenças, com $100 \mathrm{ml}$ favorecendo a maior lixiviação na primeira e segunda épocas. Diante disto, ficou evidente que, de maneira geral, o uso de 90 minutos, por aumentar a quantidade de potássio lixiviado, é desfavorável a leitura em fotômetro de chama, principalmente quando combinado com $100 \mathrm{ml}$ de água.

Tabela 22. Média dos resultados de lixiviação de potássio para o cultivar BR 38 conduzida à temperatura de $30^{\circ} \mathrm{C}$, durante a primeira época do experimento III. Piracicaba, 1993.

\begin{tabular}{|c|c|c|c|c|c|c|}
\hline \multirow{3}{*}{ Tratamento } & \multicolumn{5}{|c|}{ Lote } & \multirow{3}{*}{ Média } \\
\hline & 1 & 2 & 3 & 4 & 5 & \\
\hline & \multicolumn{5}{|c|}{ ppm K/g semente } & \\
\hline $75 \mathrm{ml} / 30 \mathrm{~min}$ & 578 & 501 & 583 & 374 & 581 & $523 \mathrm{~B}^{\mathrm{I}}$ \\
\hline $75 \mathrm{ml} / 60 \mathrm{~min}$ & 627 & 602 & 658 & 503 & 693 & $616 \mathrm{C}$ \\
\hline $75 \mathrm{ml} / 90 \mathrm{~min}$ & 698 & 642 & 745 & 524 & 693 & $660 \mathrm{C}$ \\
\hline $100 \mathrm{ml} / 30 \mathrm{~min}$ & 407 & 409 & 537 & 327 & 532 & $442 \mathrm{~A}$ \\
\hline $100 \mathrm{ml} / 60 \mathrm{~min}$ & 616 & 617 & 716 & 485 & 733 & $633 \mathrm{C}$ \\
\hline $100 \mathrm{ml} / 90 \mathrm{~min}$ & 712 & 715 & 787 & 651 & 826 & $738 \mathrm{D}$ \\
\hline Média & $606 b^{l}$ & $581 \mathrm{~b}$ & $671 \mathrm{c}$ & $477 \mathrm{a}$ & $676 \mathrm{c}$ & 602 \\
\hline
\end{tabular}

${ }^{1}$ Médias seguidas por letras distintas diferem entre si ao nível de $5 \%$ de significância. 
Tabela 23. Média dos resultados de lixitiação de potássio para o cultivar BR 38 conduzida à temperatura de $30^{\circ} \mathrm{C}$, durante a segunda época do experimento III. Piracicaba, 1994.

\begin{tabular}{|c|c|c|c|c|c|c|}
\hline \multirow{3}{*}{ Tratamento } & \multicolumn{5}{|c|}{ Lote } & \multirow{3}{*}{ Média } \\
\hline & 1 & 2 & 3 & 4 & 5 & \\
\hline & \multicolumn{5}{|c|}{ ppm $\mathrm{K} / \mathrm{g}$ semente } & \\
\hline $75 \mathrm{ml} / 30 \mathrm{~min}$ & 555 & 541 & 589 & 498 & 628 & $562 \mathrm{~A}^{1}$ \\
\hline $75 \mathrm{ml} / 60 \mathrm{~min}$ & 586 & 572 & 657 & 517 & 658 & $598 \mathrm{~A}$ \\
\hline $75 \mathrm{ml} / 90 \mathrm{~min}$ & 650 & 647 & 740 & 611 & 762 & $682 \mathrm{C}$ \\
\hline $100 \mathrm{ml} / 30 \mathrm{~min}$ & 606 & 538 & 706 & 529 & 697 & $615 \mathrm{AB}$ \\
\hline $100 \mathrm{ml} / 60 \mathrm{~min}$ & 612 & 615 & 768 & 503 & 765 & $653 \mathrm{BC}$ \\
\hline $100 \mathrm{ml} / 90 \mathrm{~min}$ & 765 & 733 & 856 & 607 & 792 & $750 \mathrm{D}$ \\
\hline Média & $629 b^{2}$ & $607 \mathrm{~b}$ & $719 c$ & 544 a & $717 \mathrm{c}$ & 643 \\
\hline
\end{tabular}

Médias seguidas por letras distintas diferem entre si ao nível de $5 \%$ de significância.

Assim como foi constatado anteriormente para $25^{\circ} \mathrm{C}$ de embebição, também aqui os tratamentos $1(75 \mathrm{ml} / 30 \mathrm{~min})$ e $4(100 \mathrm{ml} / 30 \mathrm{~min})$ foram os que propiciaram os menores valores de lixiviação de potássio para as três épocas estudadas, indicando que o período de embebição tem maior influência no aumento da lixiviação de potássio que a quantidade de água. 
Quanto à classificação dos lotes em níveis de qualidade fisiologica. nas épocas 1 e 2 ocorreu a mesma classificação em níveis de vigor que a verificada nas épocas 1 e 2 da embebição a $25^{\circ} \mathrm{C}$. O lote 4 apresentou o melhor desempenho, diferindo dos demais. Os lotes 1 e 2 ficaram em posição intermediária, enquanto os lotes 3 e 5 foram classificados como de pior qualidade, diferindo dos demais. Na terceira época, a classificação dos lotes foi muito semelhante à das épocas 1 e 2; porém, nesta época, o lote 2 não se diferenciou estatisticamente do lote 4 , o que confirmou a tendência do lote 2 ser melhor que o 1, como foi observado na primeira e terceira épocas, quando se trabalhou com $25^{\circ} \mathrm{C}$ de embebição, e pelos resultados de condutividade elétrica e emergência das plântulas em campo da avaliação preliminar - Experimento I (Tabela 6). SIMON \& RAJA-HARUN (1972), HALLOIN (1975) e DIAS (1994) observaram estreita correspondência entre os estudos de condutividade elétrica e quantidade de potássio lixiviado durante a embebiçào de sementes de ervilha, algodão e soja, respectivamente. Por outro lado, BARROS (1988) constatou divergência entre as informações proporcionadas pelos dois testes em questão, trabalhando com sementes de soja.

DIAS (1994) ressaltou que os resultados obtidos com soja mostraramse consistentes com as informações proporcionadas por outros testes de vigor, especialmente com emergência das plântulas em campo. Já MARCOS FILHO et al. (1984) não encontraram relações entre a lixiviação de potássio e a emergência das plântulas em campo, trabalhando com sementes de soja. 
Tabela 24. Média dos resultados de lixiviação de potássio para o cultivar BR 38 conduzida à temperatura de $30^{\circ} \mathrm{C}$, durante a terceira época do experimento III. Piracicaba, 1994.

\begin{tabular}{|c|c|c|c|c|c|c|}
\hline \multirow{3}{*}{ Tratamento } & \multicolumn{5}{|c|}{ Lote } & \multirow{3}{*}{ Média } \\
\hline & 1 & 2 & 3 & 4 & 5 & \\
\hline & \multicolumn{5}{|c|}{ ppm $\mathrm{K} / \mathrm{g}$ semente } & \\
\hline $75 \mathrm{ml} / 30 \mathrm{~min}$ & 513 & 453 & 569 & 402 & 534 & $494 \mathrm{~A}^{1}$ \\
\hline $75 \mathrm{ml} / 60 \mathrm{~min}$ & 588 & 577 & 680 & 535 & 715 & $619 \mathrm{~B}$ \\
\hline $75 \mathrm{ml} / 90 \mathrm{~min}$ & 659 & 619 & 661 & 615 & 766 & $664 \mathrm{BC}$ \\
\hline $100 \mathrm{ml} / 30 \mathrm{~min}$ & 449 & 407 & 547 & 364 & 603 & $474 \mathrm{~A}$ \\
\hline $100 \mathrm{ml} / 60 \mathrm{~min}$ & 618 & 590 & 691 & 597 & 740 & $646 \mathrm{BC}$ \\
\hline $100 \mathrm{ml} / 90 \mathrm{~min}$ & 639 & 629 & 790 & 635 & 820 & $702 \mathrm{C}$ \\
\hline Média & $578 b^{1}$ & $546 \mathrm{ab}$ & $656 \mathrm{c}$ & $525 \mathrm{a}$ & $696 \mathrm{c}$ & 600 \\
\hline
\end{tabular}

${ }^{1}$ Médias seguidas por letras distintas diferem entre si ao nível de $5 \%$ de significância.

\subsection{Considerações gerais}

Assim como foi observado nos resultados obtidos a $25^{\circ} \mathrm{C}$, também a $30^{\circ} \mathrm{C}$ não houve interferência dos tratamentos na classificação dos lotes; porém menores quantidades de potássio possibilitaram leitura direta das amostras no fotômetro de chama, indicando que, com base nos resultados obtidos com o cultivar BR 38, os tratamentos I (75 $\mathrm{ml} / 30 \mathrm{~min})$ e $4(100 \mathrm{ml} / 30 \mathrm{~min})$ seriam mais indicados, por proporcionarem menores valores de lixiviação de potássio. 
Quanto à classificação dos lotes em termos de qualidade físiológica. houve uma grande semelhança entre as épocas e entre $25^{\circ} \mathrm{C}$ de embebição e $30^{\circ} \mathrm{C}$ de embebição

Na terceira época, os lotes de melhor qualidade apresentaram-se mais claramente distintos, em função das consequiências do armazenamento, o que foi detectado pelo teste de lixiviação de potássio, tanto a 25 como a $30^{\circ} \mathrm{C}$ de embebição, confirmando que o teste de lixiviaçăo de potássio tem apresentado resultados relevantes para discriminar o potencial fisiológico de lotes de sementes (MATTHEWS \& ROGERSON, 1976; MARCOS FILHO, 1979; MARCOS FILHO et al., 1982; MOSS \& MULLETT, 1982; SREERAMULU, 1983; DIAS, 1994).

Cabe ressaltar que os lotes 2 e 4 apresentaram menor lixiviação de potássio que o lote 3 , embora este último tenha apresentado maior concentração deste elemento na análise de composição química (Tabela 14) indicando que a lixiviação de potássio não dependeu diretamente da concentração desse elemento na semente, de modo que os resultados aqui obtidos permitem atribuir a maior ou menor liberação desse ion, à condição fisiológica da semente, refletindo a integridade das membranas.

\subsubsection{Cultivar IAC 15}

Os valores de $\mathrm{F}$ obtidos nas análises da variância dos dados referentes ao teste de lixiviação de potássio para o cultivar IAC 15 (Tabela 25), indicaram que houve diferenças significativas entre os tratamentos para todas as épocas e para as duas 
temperaturas de embebição. Diferenças significativas entre os lotes, porém, só foram observadas durante a terceira época quando se trabalhou com $25^{\circ} \mathrm{C}$ de embebição. Já a $30^{\circ} \mathrm{C}$ de embebição, as diferenças entre os lotes foram detectadas a partir da segunda época. Não houve interferència dos tratamentos na classificação dos lotes, com exceção dos testes realizados com embebição a $25^{\circ} \mathrm{C}$ durante a terceira época, onde apareceu efeito significativo da interação tratamentos $\mathrm{x}$ lotes.

Tabela 25. Valores de F obtidos nas análises da variância dos dados referentes ao teste de lixiviação de potássio para o cultivar IAC -15 , durante o experimento III. Piracicaba, 1994

\begin{tabular}{llcc}
\hline & & & \\
Temperatura Ealores $\mathrm{F}$ \\
\end{tabular}

** Significativo ao nivel de $1 \%$ de probabilidade.

vs Não significativo. 


\subsection{Testes de lixiviação de potássio realizados a $25^{\circ} \mathrm{C}$}

Os valores de lixiviação de potássio encontram-se nas Tabelas 26,27 e 28, respectivamente para as épocas 1,2 e 3 . Observa-se que os tratamentos diferiram entre si quanto à liberação de potássio na água de embebição; porém, apenas na terceira época houve influência dos mesmos na classificação dos lotes em níveis de vigor.

Para as três épocas estudadas, a quantidade de potássio lixiviada aumentou à medida em que se elevou o período de embebição, dentro da mesma quantidade de água. Durante a primeira e segunda épocas, quando a embebição foi feita a $25^{\circ} \mathrm{C}$, em geral $100 \mathrm{ml}$ de água favoreceu a maior lixiviação de potássio que $75 \mathrm{ml}$; na segunda época, porém, não houve diferenças de liberação de potássio entre as duas quantidades de água, dentro de um mesmo período de embebição.

Em todas as épocas, o tratamento $6(100 \mathrm{ml} / 90 \mathrm{~min})$ foi $o$ que proporcionou maior liberação de potássio na água de embebição, enquanto os tratamentos $1(75 \mathrm{ml} / 30 \mathrm{~min})$ e $4(100 \mathrm{ml} / 30 \mathrm{~min})$ foram os que exibiram menores liberações de potássio, indicando que a influência do período de embebição é mais significativa que a quantidade de água e que, períodos mais curtos são mais indicados para a leitura em fotômetro de chama. Estes resultados confirmam os obtidos com o cultivar BR 38 tanto a $25^{\circ} \mathrm{C}$ como a $30^{\circ} \mathrm{C}$ de embebição. Além disso, estudos têm mostrado que, as diferenças de lixiviação de potássio, para discriminar o potencial fisiológico de sementes, aparecem nos primeiros minutos após a embebição (MATTHEWS \& ROGERSON, 1976; SREERAMULU, 1983).

MATTHEWS \& ROGERSON (1976), trabalhando com ervilha, demonstraram que as diferenças de lixiviação de potássio entre lotes de diferentes 
qualidades fisiológicas, apareceram logo no primeiro minuto de embebição e mantiveram-se com maior intensidade até os 20 minutos. Daí em diante, as diferenças se mantiveram, porém com menor intensidade, sendo que, a última verificação, foi feita com 24 horas de embebição. DIAS (1994) obteve resposta similar trabalhando com sementes de soja, onde a separação do lote em termos de potencial fisiológico foi mais efetiva aos 60 e 90 minutos de embebição; aos 120 minutos, o teste perdeu sensibilidade, apenas indicando o lote de melhor qualidade fisiológica.

Tabela 26. Médias dos resultados de lixiviação de potássio para o cultivar IAC 15 conduzido à temperatura de $25^{\circ} \mathrm{C}$, durante a primeira época do experimento III. Piracicaba, 1993.

\begin{tabular}{|c|c|c|c|c|c|c|}
\hline \multirow{3}{*}{ Tratamento } & \multicolumn{5}{|c|}{ Lote } & \multirow{3}{*}{ Média } \\
\hline & 1 & 2 & 3 & 4 & 5 & \\
\hline & \multicolumn{5}{|c|}{ ppm K/g semente } & \\
\hline $75 \mathrm{ml} / 30 \mathrm{~min}$ & 619 & 593 & 596 & 623 & 587 & $603 A^{1}$ \\
\hline $75 \mathrm{ml} / 60 \mathrm{~min}$ & 816 & 722 & 732 & 747 & 784 & $760 \mathrm{~B}$ \\
\hline $75 \mathrm{ml} / 90 \mathrm{~min}$ & 877 & 867 & 896 & 878 & 950 & $894 \mathrm{CD}$ \\
\hline $100 \mathrm{ml} / 30 \mathrm{~min}$ & 769 & 844 & 687 & 647 & 792 & $748 \mathrm{~B}$ \\
\hline $100 \mathrm{ml} / 60 \mathrm{~min}$ & 788 & 855 & 840 & 856 & 914 & $851 \mathrm{C}$ \\
\hline $100 \mathrm{ml} / 90 \mathrm{~min}$ & 981 & 916 & 954 & 996 & 948 & $959 \mathrm{D}$ \\
\hline Média & $808 a^{1}$ & $799 a$ & $784 \mathrm{a}$ & $791 \mathrm{a}$ & $829 a$ & 802 \\
\hline
\end{tabular}

${ }^{1}$ Médias seguidas de letras distintas diferem entre si ao nível de $5 \%$ de significância. 
Tabela 27. Médias dos resultados de lixiviação de potássio para o cultivar IAC 15 conduzido à temperatura de $25^{\circ} \mathrm{C}$, durante a segunda época do experimento III. Piracicaba, 1994.

\begin{tabular}{|c|c|c|c|c|c|c|}
\hline \multirow{3}{*}{ Tratamento } & \multicolumn{5}{|c|}{ Lote } & \multirow{3}{*}{ Média } \\
\hline & 1 & 2 & 3 & 4 & 5 & \\
\hline & \multicolumn{5}{|c|}{ ppm K/g semente } & \\
\hline $75 \mathrm{ml} / 30 \mathrm{~min}$ & 612 & 690 & 621 & 661 & 689 & $654 \mathrm{~A}^{1}$ \\
\hline $75 \mathrm{ml} / 60 \mathrm{~min}$ & 900 & 833 & 819 & 838 & 824 & $843 \mathrm{~B}$ \\
\hline $75 \mathrm{ml} / 90 \mathrm{~min}$ & 907 & 879 & 826 & 867 & 913 & 878 B \\
\hline $100 \mathrm{ml} / 30 \mathrm{~min}$ & 701 & 713 & 750 & 637 & 750 & $710 \mathrm{~A}$ \\
\hline $100 \mathrm{ml} / 60 \mathrm{~min}$ & 910 & 866 & 911 & 848 & 904 & $888 \mathrm{~B}$ \\
\hline $100 \mathrm{ml} / 90 \mathrm{~min}$ & 984 & 968 & 949 & 988 & 969 & $972 \mathrm{~B}$ \\
\hline Média & $836 a^{l}$ & 825 a & $813 a$ & $806 a$ & 841 a & 824 \\
\hline
\end{tabular}

${ }^{1}$ Médias seguidas de letras distintas diferem entre si ao nível de $5 \%$ de significância. 
Tabela 28. Médias dos resultados de lixiviação de potássio para o cultivar IAC 15 conduzido à temperatura de $25^{\circ} \mathrm{C}$, durante a terceira época do experimento III. Piracicaba, 1994.

\begin{tabular}{|c|c|c|c|c|c|c|}
\hline \multirow{3}{*}{ Tratamento } & \multicolumn{5}{|c|}{ Lote } & \multirow{3}{*}{ Média } \\
\hline & 1 & 2 & 3 & 4 & 5 & \\
\hline & \multicolumn{5}{|c|}{ ppm $\mathrm{K} / \mathrm{g}$ semente } & \\
\hline $75 \mathrm{ml} / 30 \mathrm{~min}$ & $647 \mathrm{aAB}^{1}$ & $657 \mathrm{abA}$ & $669 \mathrm{abA}$ & $694 \mathrm{abAB}$ & $751 \mathrm{bAB}$ & $684 \mathrm{~A}$ \\
\hline $75 \mathrm{ml} / 60 \mathrm{~min}$ & $739 \mathrm{abBC}$ & $830 \mathrm{bcBC}$ & $723 \mathrm{aAB}$ & $797 \mathrm{abcBC}$ & $850 \mathrm{cBC}$ & $788 \mathrm{~B}$ \\
\hline $75 \mathrm{ml} / 90 \mathrm{~min}$ & $808 \mathrm{aC}$ & $839 \mathrm{aBC}$ & $899 \mathrm{aC}$ & $838 \mathrm{aCD}$ & $876 \mathrm{aCD}$ & $852 \mathrm{C}$ \\
\hline $100 \mathrm{ml} / 30 \mathrm{~min}$ & $603 a A$ & $651 \mathrm{abA}$ & $715 \mathrm{bA}$ & $691 \mathrm{abA}$ & $738 \mathrm{bA}$ & $680 \mathrm{~A}$ \\
\hline $100 \mathrm{ml} / 60 \mathrm{~min}$ & $816 a b C$ & $771 \mathrm{aB}$ & $824 \mathrm{abC}$ & $944 \mathrm{cE}$ & $874 \mathrm{bcCD}$ & $846 \mathrm{C}$ \\
\hline $100 \mathrm{ml} / 90 \mathrm{~min}$ & $836 \mathrm{aC}$ & $928 \mathrm{abC}$ & $918 \mathrm{abC}$ & $915 \mathrm{abE}$ & $957 \mathrm{bD}$ & $911 \mathrm{D}$ \\
\hline Média & $742 a$ & $779 \mathrm{ab}$ & $791 \mathrm{~b}$ & $813 b c$ & $841 \mathrm{c}$ & 793 \\
\hline
\end{tabular}

Médias seguidas de letras distintas, minúsculas nas linhas e maiúsculas nas colunas, diferem entre si ao nível de $5 \%$ de significância.

Quanto à classificação dos lotes em niveis de vigor, durante a primeira e segunda épocas não houve influência dos tratamentos na classificação dos mesmos; nestas épocas, os lotes não apresentaram diferenças estatísticas. Numericamente, no entanto, os lotes 3 e 4 apresentaram as menores liberações de potássio e o lote 5 
apresentou lixiviação mais alta que os demais, indicando assim, de acordo com SIMON \& RAJA-HARUN (1972) maior desorganização do sistema de membranas e consequentemente, menor qualidade fisiológica.

Na terceira época, porém, como já foi salientado anteriormente, ocorreu interferência dos tratamentos na classificação dos lotes. Os tratamentos 1 ( $75 \mathrm{ml} / 30$ $\mathrm{min})$ e $6(100 \mathrm{ml} / 90 \mathrm{~min})$ classificaram os lotes de forma semelhante. $O$ lote 1 apresentou a melhor qualidade fisiológica, diferindo dos demais. Os lotes 2,3 e 4 ficaram em posição intermediária enquanto o lote 5 produziu os maiores valores de lixiviação de potássio, ou seja, apresentou a pior qualidade fisiológica. $O$ tratamento $4(100 \mathrm{ml} / 30 \mathrm{~min})$ classificou os lotes de maneira próxima aos tratamentos 1 e 6 , apenas com a diferença que colocou o lote 3 como tendo qualidade fisiológica inferior, juntamente com o lote 5 . O tratamento 2 ( $75 \mathrm{ml} / 60 \mathrm{~min}$ ) mostrou-se semelhante aos demais, ao destacar o lote 5 por sua qualidade fisiológica inferior, porém discordou ao indicar o lote 3 como sendo o de melhor qualidade juntamente com o lote 1 . Os lotes 2 e 4 ficaram em posição intermediária. Já o tratamento 5 (100 ml/60 min) comportou-se diferentemente aos os demais, tanto na indicação dos melhores como na indicação dos piores lotes e o tratamento 3 (75 $\mathrm{ml} / 90 \mathrm{~min})$ não diferenciou os lotes estatisticamente.

Os testes preliminares - Experimento I (Tabela 8), através principalmente dos testes de envelhecimento acelerado e emergência das plântulas em campo, já haviam demonstrado a tendència de inferioridade do lote 5 , que foi confirmada nas três épocas do teste de lixiviação de potássio realizado a $25^{\circ} \mathrm{C}$ de embebição e, na terceira época, pelos resultados dos tratamentos 1,4 e 6 . 


\subsection{Testes de lixiviação de potássio realizados a $30^{\circ} \mathrm{C}$}

Os dados de lixiviação de potássio obtidos com embebição das sementes a $30^{\circ} \mathrm{C}$ se encontram nas Tabelas 29,30 e 31 , respectivamente para as épocas 1 , 2 e 3

Observou-se que os valores de lixiviação de potássio foram mais altos a $30^{\circ} \mathrm{C}$ que a $25^{\circ} \mathrm{C}$, fato este verificado através da comparação das médias gerais entre as Tabelas 29,30 e $31\left(30^{\circ} \mathrm{C}\right)$ com as Tabelas 26,27 e $28\left(25^{\circ} \mathrm{C}\right)$. Embora seja conhecido que a taxa de lixiviação é afetada pela temperatura (SHORT \& LACY, 1976; DUKE et al., 1983; MURPHY \& NOLAND, 1982), o efeito da temperatura tem sido apenas discutido em relação a seu efeito sobre a difusão e viscosidade da água (POWELL \& MATTHEWS, 1981; MURPHY \& NOLAND, 1982; DUKE et al., 1983) e, também, no mecanismo de reparo da membrana (DUKE et al., 1983).

MABACH \& MAYER (1985) trabalhando com ervilha concluiu que a lixiviação de eletrólitos, açúcares e proteínas foi maior a $25^{\circ} \mathrm{C}$ que a $5^{\circ} \mathrm{C}$ e que a temperatura inicial controla a taxa de lixiviação subsequente, mesmo se as sementes forem transferidas para outra temperatura, sugerindo claramente que a lixiviação é um processo controlado e não simplesmente passivo.

Para as três épocas estudadas, não houve interferência dos tratamentos na classificação dos lotes em niveis de vigor, como já havia sido constatado através do teste F (Tabela 25) por não serem significativos os efeitos da interação tratamentos $x$ lotes; porém, houve diferenças significativas entre os tratamentos para as três épocas estudadas. 
Como foi observado para os testes realizados a $25^{\circ} \mathrm{C}$, os valores de lixiviação também aumentaram com a elevação do periodo de embebição, considerando-se uma mesma quantidade de água. Para as três épocas, nos períodos de embebição de 60 e 90 minutos, $100 \mathrm{ml}$ de água provocou aumentos significativos na quantidade de potássio lixiviado das sementes. O período de 30 minutos apresentou comportamento variável, dependendo da época.

Tabela 29. Médias dos resultados de lixiviação de potássio para o cultivar IAC 15 conduzido à temperatura de $30^{\circ} \mathrm{C}$, durante a primeira época do experimento III. Piracicaba, 1993.

\begin{tabular}{|c|c|c|c|c|c|c|}
\hline \multirow{3}{*}{ Tratamento } & \multicolumn{5}{|c|}{ Lote } & \multirow{3}{*}{ Média } \\
\hline & 1 & 2 & 3 & 4 & 5 & \\
\hline & \multicolumn{5}{|c|}{ ppm K/g semente } & \\
\hline $75 \mathrm{ml} / 30 \mathrm{~min}$ & 722 & 743 & 795 & 808 & 863 & $786 \mathrm{~A}^{1}$ \\
\hline $75 \mathrm{ml} / 60 \mathrm{~min}$ & 869 & 875 & 902 & 877 & 879 & $881 \mathrm{~B}$ \\
\hline $75 \mathrm{ml} / 90 \mathrm{~min}$ & 1002 & 1048 & 1016 & 997 & 997 & $1012 \mathrm{CD}$ \\
\hline $100 \mathrm{ml} / 30 \mathrm{~min}$ & 855 & 847 & 831 & 778 & 845 & $831 \mathrm{AB}$ \\
\hline $100 \mathrm{ml} / 60 \mathrm{~min}$ & 939 & 903 & 939 & 1019 & 983 & $956 \mathrm{C}$ \\
\hline $100 \mathrm{ml} / 90 \mathrm{~min}$ & 1035 & 1012 & 1072 & 1085 & 1088 & $1058 \mathrm{D}$ \\
\hline Média & $904 \mathrm{a}^{1}$ & $905 \mathrm{a}$ & $926 \mathrm{a}$ & 927 a & $942 a$ & 921 \\
\hline
\end{tabular}

${ }^{1}$ Médias seguidas de letras distintas diferem entre si ao nível de $5 \%$ de significância. 
Tabela 30. Médias dos resultados de lixiviação de potássio para o cultivar IAC 15 conduzido à temperatura de $30^{\circ} \mathrm{C}$, durante a segunda época do experimento III. Piracicaba, 1994.

\begin{tabular}{|c|c|c|c|c|c|c|}
\hline \multirow{3}{*}{ Tratamento } & \multicolumn{5}{|c|}{ Lote } & \multirow{3}{*}{ Média } \\
\hline & 1 & 2 & 3 & 4 & 5 & \\
\hline & \multicolumn{5}{|c|}{ ppm K/g semente } & \\
\hline $75 \mathrm{ml} / 30 \mathrm{~min}$ & 737 & 765 & 803 & 850 & 806 & $792 \mathrm{~A}^{\mathrm{t}}$ \\
\hline $75 \mathrm{ml} / 60 \mathrm{~min}$ & 821 & 853 & 831 & 840 & 848 & $838 \mathrm{~A}$ \\
\hline $75 \mathrm{ml} / 90 \mathrm{~min}$ & 935 & 941 & 959 & 987 & 1015 & $967 \mathrm{~B}$ \\
\hline $100 \mathrm{ml} / 30 \mathrm{~min}$ & 764 & 787 & 861 & 802 & 916 & $826 \mathrm{~A}$ \\
\hline $100 \mathrm{ml} / 60 \mathrm{~min}$ & 970 & 931 & 1022 & 1006 & 1071 & $1000 \mathrm{BC}$ \\
\hline $100 \mathrm{ml} / 90 \mathrm{~min}$ & 1039 & 997 & 1028 & 1053 & 1099 & $1044 \mathrm{C}$ \\
\hline Média & 878 a & $879 a$ & $917 \mathrm{ab}$ & $923 \mathrm{ab}$ & $959 \mathrm{~b}$ & 911 \\
\hline
\end{tabular}

${ }^{1}$ Médias seguidas de letras distintas diferem entre si ao nível de $5 \%$ de significância.

A classificação dos lotes em níveis de vigor só foi possivel a partir da segunda época de teste, pois, como já havia sido observado nos testes preliminares (Experimento I), os lotes do cultivar IAC 15 não apresentaram diferenças significativas de vigor. 
Tabela 31. Médias dos resultados de lixiviação de potássio para o cultivar IAC 15 conduzido à temperatura de $30^{\circ} \mathrm{C}$, durante a terceira época do experimento III. Piracicaba, 1994.

\begin{tabular}{|c|c|c|c|c|c|c|}
\hline \multirow{3}{*}{ Tratamento } & \multicolumn{5}{|c|}{ Lote } & \multirow{3}{*}{ Média } \\
\hline & 1 & 2 & 3 & 4 & 5 & \\
\hline & \multicolumn{5}{|c|}{ ppm K/g semente } & \\
\hline $75 \mathrm{ml} / 30 \mathrm{~min}$ & 704 & 794 & 802 & 801 & 791 & $778 \mathrm{~B}^{1}$ \\
\hline $75 \mathrm{ml} / 60 \mathrm{~min}$ & 728 & 817 & 831 & 826 & 859 & $812 \mathrm{~B}$ \\
\hline $75 \mathrm{ml} / 90 \mathrm{~min}$ & 916 & 928 & 949 & 961 & 987 & $948 \mathrm{C}$ \\
\hline $100 \mathrm{ml} / 30 \mathrm{~min}$ & 610 & 694 & 709 & 686 & 700 & $680 \mathrm{~A}$ \\
\hline $100 \mathrm{ml} / 60 \mathrm{~min}$ & 900 & 982 & 927 & 1019 & 1003 & $966 \mathrm{CD}$ \\
\hline $100 \mathrm{ml} / 90 \mathrm{~min}$ & 984 & 1008 & 986 & 1010 & 1059 & $1009 \mathrm{D}$ \\
\hline Média & $807 \mathrm{a}^{1}$ & $870 \mathrm{~b}$ & $867 \mathrm{~b}$ & $884 b$ & $900 \mathrm{~b}$ & 866 \\
\hline
\end{tabular}

${ }^{1}$ Médias seguidas de letras distintas diferem entre si ao nível de $5 \%$ de significância.

Os lotes não se diferenciaram durante a primeira época de testes, porém através de valores numéricos (Tabela 29), notou-se uma tendência dos lotes 1 e 2 possuirem melhor qualidade fisiológica, uma vez que exibiram valores próximos de lixiviação de potássio e inferiores aos demais lotes. $O$ lote 5 mostrou a tendência de 
diferenciar-se, com alto valor de lixiviação de potássio, quando comparado aos demais. Estas tendências foram confirmadas na segunda época (Tabela 30), onde os lotes 1 e 2 novamente exibiram valores menores que os demais de lixiviação de potássio. O lote 5 apresentou valor estatisticamente inferior aos demais, enquanto os lotes 3 e 4 permaneceram em posição intermediária.

$\mathrm{Na}$ época 3 (Tabela 31), os dados de lixiviação de potássio entre os lotes do cultivar IAC 15 mostraram que o lote 1 revelou qualidade fisiológica significativamente superior à dos demais, que não diferiram entre si. Numericamente, no entanto, o lote 5 apresentou valores mais altos de lixiviação de potássio e portanto menor qualidade fisiológica. Estas observações confirmaram as efetuadas durante a segunda época e as tendências relatadas nos resultados da primeira época, referentes ao uso de $30^{\circ} \mathrm{C}$, e nas tendências gerais verificadas para os resultados dos testes conduzidos a $25^{\circ} \mathrm{C}$, com sementes de IAC 15.

\subsection{Considerações gerais}

Os dados obtidos com o cultivar IAC 15 demonstraram que, independente da temperatura de embebição, os tratamentos 1 ( $75 \mathrm{ml} / 30 \mathrm{~min})$ e $4(100 \mathrm{ml} / 30$ min) proporcionaram a liberação de menores quantidades de lixiviados de potássio, enquanto o tratamento $6(100 \mathrm{ml} / 90 \mathrm{~min})$ levou a valores mais altos. De maneira geral, não houve interferência dos tratamentos na classificação dos lotes em niveis de vigor quando 
a embebição foi feita a $25^{\circ} \mathrm{C}$, com exceção da época 3. Nesta época foi significativo o efeito da interação tratamentos $\mathrm{x}$ lotes na análise da variância.

A classificação dos lotes em níveis de vigor somente foi possível na terceira época, quando a embebição foi feita a $25^{\circ} \mathrm{C}$, e a partir da segunda época, quando a embebição foi feita a $30^{\circ} \mathrm{C}$, indicando que procedendo-se a embebição a $30^{\circ} \mathrm{C}$ o teste pode se tornar mais sensível a pequenas diferenças de qualidade fisiológica entre os lotes. Na segunda época, com a temperatura de $30^{\circ} \mathrm{C}$, a classificação dos lotes foi semelhante à obtida na terceira época; nesta última, houve uma melhor definição quanto a indicação do melhor lote, ou seja, a do lote 1 .

Os resultados obtidos a $30^{\circ} \mathrm{C}$ de embebição nas épocas 2 e 3 foram semelhantes aos verificados a $25^{\circ} \mathrm{C}$ de embebição na terceira época. Diante dos dados obtidos nesta época, podem ser confirmadas as considerações efetuadas no item 4.3.2.1.3. quanto às relações entre a concentração de potássio na semente e os resultados do teste de lixiviação de $\mathrm{K}^{+}$, pois observou-se que os lotes 2 e 4 , possuindo quantidades semelhantes de potássio (Tabela 15), comportaram-se de forma diferente quanto à lixiviação; o lote 4 apresentou valores mais elevados, tanto a 25 como a $30^{\circ} \mathrm{C}$.

\subsubsection{Outros testes para avaliação da qualidade fisiológica}

Os outros testes para avaliação da qualidade fisiológica foram conduzidos paralelamente ao teste de lixiviação de potássio (item 4.3.2) para cada cultivar e época de avaliação. 


\subsubsection{Cultivar BR 38}

Os valores de $\mathrm{F}$ obtidos nas análises da variância dos dados referentes aos testes de laboratório e de campo para o cultivar BR 38 durante as três épocas de condução do experimento, se encontram na Tabela 32. A análise dos dados mostrou que apenas os testes de envelhecimento acelerado e de condutividade elétrica revelaram diferenças significativas entre os lotes nas três épocas. Os dados de germinação, primeira contagem da germinação e emergência das plântulas em campo, só mostraram diferenças significativas entre os lotes durante a terceira época de testes.

Tabela 32. Valores de $\mathrm{F}$ obtidos nas análises da variância dos dados referentes aos testes de laboratório e de campo, realizados com os lotes do cultivar BR $38 \mathrm{em}$ cada época de avaliação durante o experimento III. Piracicaba, 1994.

\begin{tabular}{lccccc}
\hline Época & $\begin{array}{c}\text { Germina- } \\
\text { ção }\end{array}$ & $\begin{array}{c}1^{\mathrm{a}} \text {. cont. } \\
\text { germina- } \\
\text { ção }\end{array}$ & $\begin{array}{c}\text { Env. } \\
\text { acele- } \\
\text { rado }\end{array}$ & $\begin{array}{c}\text { Cond. } \\
\text { elétri- } \\
\text { ca }\end{array}$ & $\begin{array}{c}\text { Emerg. } \\
\text { pl em } \\
\text { campo }\end{array}$ \\
\hline 1 & $2,5995^{\mathrm{NS}}$ & $0,7795^{\mathrm{NS}}$ & $3,1018^{*}$ & $7,9234^{* *}$ & $1,7291^{\mathrm{NS}}$ \\
2 & $1,9161^{\mathrm{NS}}$ & $1,5505^{\mathrm{NS}}$ & $5,5962^{* *}$ & $8,6456^{* *}$ & $2,2945^{\mathrm{NS}}$ \\
3 & $5,5967^{* *}$ & $10,1143^{* *}$ & $8,3438^{* *}$ & $13,2036^{* *}$ & $4,0943^{*}$ \\
\hline
\end{tabular}

* Significativo ao nivel de $5 \%$ de probabilidade.

* Significativo ao nível de $1 \%$ de probabilidade.

Ns Não significativo. 
De acordo com os testes realizados na primeira época (Tabela 33), apenas os testes de envelhecimento acelerado e condutividade elétrica classificaram os lotes em diferentes níveis de vigor. $O$ teste de envelhecimento acelerado classificou o lote 5 como sendo diferente do lote 3 e com melhor desempenho que este. Os lotes 1,2 e 4 năo se diferenciaram nem do lote 5 nem do lote 3 , ficando em posição intermediária.

Tabela 33. Média dos resultados de germinação $(G)$, primeira contagem de germinação (PCG), envelhecimento acelerado (EA), condutividade elétrica (CE), emergência das plântulas em campo $(\mathrm{EC})$ e umidade $(\mathrm{U})$ para o cultivar $\mathrm{BR}$ 38, durante a primeira época do experimento III. Piracicaba, 1993.

\begin{tabular}{|c|c|c|c|c|c|c|}
\hline Lotes & G & PCG & EA & CE & EC & U \\
\hline 1 & $100 a^{1}$ & $98 a$ & $97 a b$ & $61,57 \mathrm{a}$ & $63 a$ & 9,5 \\
\hline 2 & $98 a$ & $97 a$ & $95 a b$ & $61,62 a$ & $71 a$ & 9,5 \\
\hline 3 & $96 \mathbf{a}$ & $95 a$ & $91 \mathrm{~b}$ & $84,78 \mathrm{c}$ & $69 a$ & 9,4 \\
\hline 4 & $100 \mathbf{a}$ & $98 \mathrm{a}$ & $97 a b$ & $67,26 \mathrm{ab}$ & $75 a$ & 9,5 \\
\hline 5 & $96 a$ & $95 a$ & $99 a$ & $79,81 b c$ & $59 a$ & 9,5 \\
\hline CV $(\%)$ & 6,7 & 8,1 & 6,0 & 10,7 & 10,7 & - \\
\hline
\end{tabular}

'Médias seguidas por letras distintas diferem entre si so nivel de $5 \%$ de significância. 
Esta classificação foi diferente da apresentada pelo teste de condutividade elétrica. Este classificou os lotes 3 e 5 como os de menor qualidade fisiológica e diferentes dos lotes 1,2 e 4 . Tal tendência foi observada nos resultados numéricos do teste de germinação; a primeira contagem da germinação também apresentou tendência semelhante. Os resultados de emergência das plântulas em campo mostraram a tendência do lote 5 ser menos vigoroso que os demais, ou seja, contrária aos resultados apresentados pelo teste de envelhecimento acelerado, mas concordante com os demais testes.

Quando se compara com os resultados do teste de lixiviação de potássio notou-se que, tanto a $25^{\circ} \mathrm{C}$ (Tabela 19) como a $30^{\circ} \mathrm{C}$ (Tabela 22) de embebição os lotes 3 e 5 mostraram-se estatisticamente diferentes dos lotes 1,2 e 4 , o que concorda com os resultados do teste de condutividade elétrica. Segundo MARCOS FILHO et al. (1982), QUEIROGA \& PARRA (1989) e PRETE (1992), grande parte da condutividade elétrica se deve à lixiviação de íons potássio. Estudos realizados por HALLOIN (1975), com sementes de algodão, constataram que a concentração de íons $\mathrm{K}^{+}$mostrou correspondência com a condutividade elétrica dos exsudatos. A tendência numérica apresentada pelos testes de germinação, primeira contagem da germinação e os resultados numéricos do teste de emergência das plântulas em campo também indicam similaridade com os resultados do teste de lixiviação de potássio.

O teste de envelhecimento acelerado destacou a inferioridade do lote 3 em relação aos demais, o que também foi destacado pelo teste de lixiviação de potássio. 
Notou-se, também, que o teste de lixiviação de potássio, independente da temperatura de embebição utilizada, destacou a qualidade do lote 4 seguido pela do lote 2, em relação ao lote 1 , o que não foi revelado pelos outros testes realizados nesta época; porém, foi constatado posteriormente pelos testes de condutividade elétrica. WOODSTOCK et al. (1985) trabalhando com algodão, concluíram que a avaliação da quantidade de $\mathrm{K}^{-} \mathrm{e}$ $\mathrm{Ca}^{++}$liberados pelas sementes embebidas mostrou-se um indicador de qualidade fisiológica mais eficiente do que a quantidade de eletrólitos totais, o que também foi verificado neste estudo, através da sensibilidade do teste de lixiviação de potássio que destacou o lote 4 logo na primeira época, enquanto os demais testes para verificação da qualidade fisiológica só o fizeram na terceira época quando as diferenças de vigor foram acentuadas pelo armazenamento.

$\mathrm{Na}$ segunda época de testes (Tabela 34), novamente apareceram diferenças significativas entre os lotes somente nos resultados dos testes de envelhecimento acelerado e condutividade.

Os resultados do teste de condutividade elétrica foram comparáveis aos do teste de envelhecimento acelerado, ao indicar os lotes 3 e 5 como tendo os maiores valores de condutividade e portanto menor vigor. O lote 4 , seguido do lote 1 , apresentou-se estatisticamente diferente do lote 3 sendo, portanto, lotes de qualidade superior Vários autores consideraram o teste de condutividade elétrica como adequado para a separação eficiente de lotes de sementes com diferentes níveis de qualidade (KULIK \& YAKLICH, 1982, MARCOS FILHO et al., 1986 e BARROS, 1988). Por outro lado, HEPBURN et al. (1984) não obtiveram uma ordenação eficiente de lotes de sementes de soja, com diferentes niveis de vigor, destacando as dificuldades do teste para a identificação de níveis médios de vigor. 
Os testes de germinação e primeira contagem da germinação, apesar de não terem apresentado diferenças estatísticas entre os lotes, tenderam a mostrar, através dos valores numéricos, a inferioridade dos lotes 3 e 5 em relação aos demais. Já o teste de emergência das plântulas em campo mostrou a tendência de inferioridade do lote 3 , em relação aos demais.

Tabela 34. Média dos resultados de germinação $(G)$, primeira contagem de germinação (PCG), envelhecimento acelerado (EC), condutividade elétrica (CE), emergência das plântulas em campo (EC) e umidade (U) para o cultivar BR 38 durante a segunda época do experimento III. Piracicaba, 1994.

\begin{tabular}{|c|c|c|c|c|c|c|}
\hline Lotes & $\begin{array}{l}\mathrm{G} \\
\%\end{array}$ & $\begin{array}{c}\text { PCG } \\
\%\end{array}$ & $\begin{array}{l}\text { EA } \\
\%\end{array}$ & $\begin{array}{c}\mathrm{CE} \\
\mu \mathrm{mhos} / \mathrm{cm} / \mathrm{g}\end{array}$ & $\begin{array}{c}\text { Emergên- } \\
\%\end{array}$ & $\begin{array}{l}\mathrm{U} \\
\%\end{array}$ \\
\hline 1 & $97 a^{1}$ & $93 a$ & $98 a$ & $59,15 a b$ & $95 a$ & 9,3 \\
\hline 2 & $96 a$ & $95 a$ & $95 \mathrm{ab}$ & $62,56 \mathrm{abc}$ & $92 a$ & 9,1 \\
\hline 3 & $91 a$ & $90 a$ & $89 b$ & $76,36 \mathrm{c}$ & $85 a$ & 9,2 \\
\hline 4 & $98 a$ & $98 \mathrm{a}$ & $93 a b$ & $49,66 \mathrm{a}$ & $96 a$ & 9,6 \\
\hline 5 & $93 a$ & $92 a$ & $92 b$ & $70,47 \mathrm{bc}$ & $94 a$ & 9,1 \\
\hline $\mathrm{CV}(\%)$ & 7,7 & 9,4 & 4,3 & 11,0 & 7,9 & - \\
\hline
\end{tabular}

'Médias seguidas por letras distintas diferem entre si ao nível de $5 \%$ de significância. 
Os resultados obtidos no teste de lixiviação de potássio durante a segunda época de testes tanto a $25^{\circ} \mathrm{C}$ de embebição (Tabela 20) como a $30^{\circ} \mathrm{C}$ (Tabela 23), mostraram que houve diferenças estatísticas entre os lotes. $O$ lote 4 apresentou-se com menor lixiviação de potássio e, portanto, alta qualidade físiológica, enquanto os lotes 3 e 5 apresentaram-se com qualidade inferior aos demais. Estes resultados foram também revelados, através de diferenças estatísticas, pelos testes de envelhecimento acelerado e condutividade elétrica, principalmente quanto à indicação da inferioridade dos lotes 3 e 5 . Os testes de germinação e primeira contagem da germinação, apesar de não mostrarem diferenças estatísticas entre os lotes, concordaram com o teste de lixiviação de potássio na indicação dos lotes 3 e 5 . A emergência das plântulas em campo também não separou os lotes; porém o comportamento do lote 3 , obtendo o pior desempenho em campo, foi compativel com as indicações do teste de lixiviação de potássio. Tais resultados confirmam os obtidos por vários autores, que ressaltam o potencial do teste de lixiviação de potássio para discriminar lotes de diferentes qualidades fisiológicas (MATTHEWS \& ROGERSON, 1976;'MARCOS FILHO, 1979; MARCOS FILHO et al., 1982; MOSS \& MULLETT, 1982; SREERAMULU, 1983; DIAS, 1994).

Quanto à indicacão de lotes de melhor qualidade, o teste de condutividade elétrica destacou o lote 4 em relação aos lotes 1 e 2 , concordando com 0 teste de lixiviação de potássio, que já vinha apresentando este resultado desde a primeira época. Algumas pesquisas tem relacionado os resultados do teste de lixiviação de potássio ao de condutividade elétrica (SIMON \& RAJA-HARUN, 1972; PANDEY, 1989b; DONI FILHO, 1992; PRETE, 1992; DIAS, 1994); porém nesse trabalho, o teste de lixiviação de potássio foi mais sensível. 
$\mathrm{Na}$ terceira época (Tabela 35 ), todos os testes mostraram diferenças significativas entre os lotes. O teste de germinação mostrou a inferioridade do lote 3 em relação aos demais, embora não tenha sido diferente do lote 5. O lote 4, apresentou o maior valor de germinação, embora não seja diferente dos lotes 1 e 2 . A primeira contagem da germinação apresentou resultados bem próximos à germinação, tanto nesta época como nas duas anteriores, o que pode ser atribuído ao fato de que as avaliações foram realizadas com a mesma amostra.

Tabela 35. Média dos resultados de germinação $(G)$, primeira contagem de germinação (PCG), envelhecimento acelerado (EA), condutividade elétrica (CE), emergência das plântulas em campo (EC) e umidade (U) para o cultivar BR 38, durante a terceira época do experimento III. Piracicaba, 1994.

\begin{tabular}{|c|c|c|c|c|c|c|}
\hline Lotes & $\begin{array}{l}\mathrm{G} \\
\%\end{array}$ & $\begin{array}{c}\text { PCG } \\
\%\end{array}$ & $\begin{array}{l}\text { EA } \\
\%\end{array}$ & $\begin{array}{c}\mathrm{CE} \\
\mu \mathrm{mhos} / \mathrm{cm} / \mathrm{g}\end{array}$ & $\begin{array}{c}\text { EC } \\
\%\end{array}$ & $\begin{array}{l}U \\
\%\end{array}$ \\
\hline 1 & $96 \mathrm{ab}^{1}$ & $91 \mathrm{abc}$ & $95 \mathrm{ab}$ & $57,50 \mathrm{a}$ & $90 \mathrm{ab}$ & 9,7 \\
\hline 2 & $93 \mathrm{abc}$ & $92 \mathrm{ab}$ & $97 a b$ & $54,56 a$ & $92 \mathrm{ab}$ & 9,9 \\
\hline 3 & $85 \mathrm{c}$ & $83 c$ & $84 \mathrm{bc}$ & $83,37 \mathrm{~b}$ & $83 b$ & 9,6 \\
\hline 4 & $97 a$ & $96 a$ & $98 \mathrm{a}$ & $58,53 \mathrm{a}$ & $94 a$ & 9,8 \\
\hline 5 & $88 b c$ & $86 b c$ & $78 \mathrm{c}$ & $79,60 \mathrm{~b}$ & $90 \mathrm{ab}$ & 9,9 \\
\hline $\mathrm{CV}(\%)$ & 6,3 & 4,3 & 8,4 & 11,2 & 5,2 & - \\
\hline
\end{tabular}

${ }^{1}$ Médias seguidas por letras distintas diferem entre si ao nivel de $5 \%$ de significância. 
O teste de envelhecimento acelerado também relacionou os lotes de maneira próxima à apresentada pelos testes de germinação e primeira contagem, como também manteve a tendência já apresentada na segunda época, ou seja, o lote 5 se diferenciou dos lotes 1,2 e 4 . O lote 3 não se diferenciou do lote 5 . O lote 4 se destacou por apresentar maior vigor, porém não se diferenciou dos lotes 1 e 2 .

O teste de condutividade elétrica também apresentou resultados que confirmaram os obtidos nos outros testes desta época, como também as tendências apresentadas pelas épocas 1 e 2, já discutidas, no que se refere à classificação dos lotes 3 e 5 como sendo de qualidade inferior aos demais.

A emergência das plântulas em campo, apresentou resultados concordantes com os outros testes, ao indicar o lote 3 como de qualidade inferior e, também, o lote 4 como de alto vigor, apesar de não ser estatisticamente diferente dos lotes 1,2 e 5 .

Quando se compararam os resultados desta época com aqueles obtidos no teste de lixiviação de potássio tanto a $25^{\circ} \mathrm{C}$ quanto a $30^{\circ} \mathrm{C}$ (Tabelas 21 e 24 , respectivamente), notou-se que há concordância entre eles tanto na indicação dos lotes 3 e 5 como de menor vigor, quanto na indicação dos lotes 4,1 e 2 como de qualidade superior, com destaque para o lote 4.

É interessante notar que este destaque para o lote 4 somente foi evidenciado pelos outros testes para verificação da qualidade fisiológica na terceira época, onde o efeito do armazenamento tornou as diferenças de qualidade entre os lotes mais pronunciadas, enquanto que o teste de lixiviação de potássio já o fazia na primeira época. 
Estes resultados indicaram, portanto, eficiência do método em classificar os lotes em niveis de qualidade fisiológica, contrariando observações efetuadas por MARCOS FILHO et al (1984) e BARROS (1988), também com sementes de soja.

O grau de umidade das sementes por ocasião dos testes durante as três épocas se situou em torno de 9,1 a $9,9 \%$, ou seja, houve pequenas diferenças entre os lotes, o que proporcionou maior garantia na comparação dos resultados, considerando-se que a uniformização da umidade das sementes é imprescindivel para a padronização das avaliações e obtenção de resultados consistentes (MATTHEWS, 1981, MARCOS FILHO et al., 1987 e LOEFFLER et al., 1988).

\subsubsection{Cultivar IAC 15}

Os valores de $\mathrm{F}$ obtidos nas análises da variância dos dados referentes aos testes de laboratório e de campo, realizados com os lotes do cultivar IAC 15 nas três épocas de avaliação, se encontram na Tabela 36. Verificou-se que os testes de germinação, primeira contagem de germinação e emergência das plântulas em campo não mostraram diferenças significativas entre os lotes. $O$ teste de condutividade elétrica mostrou diferenças significativas apenas na primeira época, enquanto o teste de envelhecimento acelerado, apenas na terceira época. 
Tabela 36. Valores de $\mathrm{F}$ obtidos nas análises da variância dos dados referentes aos testes de laboratório e de campo, realizados com os lotes do cultivar IAC 15, em cada época de avaliação durante o experimento III. Piracicaba, 1994.

\begin{tabular}{cccccc}
\hline Época & $\begin{array}{c}\text { Germina- } \\
\text { ção }\end{array}$ & $\begin{array}{c}1^{\mathrm{a}} \text { Cont. } \\
\text { germina- } \\
\text { ção }\end{array}$ & $\begin{array}{c}\text { Env. } \\
\text { acele- } \\
\text { rado }\end{array}$ & $\begin{array}{c}\text { Cond. } \\
\text { elétri- } \\
\text { ca }\end{array}$ & $\begin{array}{c}\text { Emerg. } \\
\text { pl em } \\
\text { campo }\end{array}$ \\
\hline 1 & $2,4828^{\mathrm{NS}}$ & $2,5908^{\mathrm{NS}}$ & $0,2214^{\mathrm{NS}}$ & $2,8499^{*}$ & $0,7881^{\mathrm{NS}}$ \\
2 & $1,7782^{\mathrm{NS}}$ & $0,8278^{\mathrm{NS}}$ & $0,5242^{\mathrm{NS}}$ & $0,8318^{\mathrm{NS}}$ & $2,5716^{\mathrm{NS}}$ \\
3 & $1,3016^{\mathrm{NS}}$ & $0,9690^{\mathrm{NS}}$ & $3,3208^{*}$ & $2,2385^{\mathrm{NS}}$ & $1,0142^{\mathrm{NS}}$ \\
\hline
\end{tabular}

* Significativo ao nível de $5 \%$ de probabilidade.

Ns Não significativo.

Os resultados referentes à primeira época (Tabela 37) mostraram que o teste de condutividade elétrica separou os lotes, apontando o lote 2 como tendo a menor condutividade elétrica e portanto maior vigor, sendo diferente do lote 5 que apresentou a maior condutividade. KULIK \& YAKLICH (1982), MARCOS FILHO et al., (1986) e BARROS (1988) também obtiveram separação eficiente de lotes de sementes com o teste de condutividade elétrica. Os testes de germinação e primeira contagem da germinação, apesar de não separarem os lotes estatisticamente, apresentaram a tendência de indicar o lote 2 como de melhor qualidade que os demais, concordando, portanto, com o teste de condutividade. 
Tabela 37. Média dos resultados de germinação $(G)$, primeira contagem de germinação (PCG), envelhecimento acelerado (EA), condutividade elétrica (CE), emergência das plântulas em campo (EC) e umidade (U) para o cultivar IAC 15, durante a primeira época do experimento III. Piracicaba, 1993.

\begin{tabular}{|c|c|c|c|c|c|c|}
\hline Lotes & $\begin{array}{l}\mathrm{G} \\
\%\end{array}$ & $\begin{array}{c}\text { PCG } \\
\%\end{array}$ & $\begin{array}{l}\text { EA } \\
\%\end{array}$ & $\begin{array}{c}\mathrm{CE} \\
\mu \mathrm{mhos} / \mathrm{cm} / \mathrm{g}\end{array}$ & $\begin{array}{c}\mathrm{EC} \\
\%\end{array}$ & $\begin{array}{l}U \\
\%\end{array}$ \\
\hline 1 & $93 \mathbf{a}^{1}$ & $84 a$ & $90 a$ & $79,95 \mathrm{ab}$ & $53 a$ & 9,2 \\
\hline 2 & $98 a$ & $91 \mathrm{a}$ & $92 a$ & $77,32 \mathrm{a}$ & $55 \mathrm{a}$ & 9,6 \\
\hline 3 & $94 a$ & $88 \mathrm{a}$ & $91 \mathrm{a}$ & $80,52 \mathrm{ab}$ & $62 \mathrm{a}$ & 9,5 \\
\hline 4 & $91 \mathrm{a}$ & $83 a$ & $90 a$ & $79,06 \mathrm{ab}$ & $55 a$ & 9,4 \\
\hline 5 & $92 a$ & $87 a$ & $89 a$ & $87,83 b$ & $61 a$ & 9,5 \\
\hline CV $(\%)$ & 5,9 & 4,7 & 6,6 & 6,0 & 10,7 & - \\
\hline
\end{tabular}

${ }^{1}$ Médias seguidas por letras distintas diferem entre si ao nivel de $5 \%$ de significância.

No teste de envelhecimento acelerado os valores pouco variaram (de 89 a $92 \%$ ) fícando difícil perceber alguma tendência; o menor valor, $89 \%$, obtido pelo lote 5 , confirmou os resultados obtidos no teste de condutividade elétrica.

Os valores de emergência das plântulas em campo foram, em geral, baixos, indicando que o teste foi drástico com todos os lotes. $\mathrm{O}$ valor mais baixo foi o do lote 1 , o que não condiz com os resultados dos outros testes.

$\mathrm{O}$ teste de lixiviação de potássio realizado tanto a $25^{\circ} \mathrm{C}$ (Tabela 26) como a $30^{\circ} \mathrm{C}$ (Tabela 29) não mostrou diferenças estatísticas entre os lotes; porém há 
concordância com o teste de condutividade elétrica e com os testes de envelhecimento acelerado na indicação do lote 5 como sendo de qualidade inferior.

Quanto à indicação de lotes de melhor desempenho não houve concordância entre as tendências apresentadas pelo teste de lixiviação de potássio realizado a $25^{\circ} \mathrm{C}$ de embebição com os demais testes; porém, houve entre o teste de lixiviação de potássio realizado a $30^{\circ} \mathrm{C}$ com o teste de condutividade elétrica, que destacou o lote 2 dos demais, embora não tenha sido diferente dos lotes 1,3 e 4 , enquanto a lixiviação de potássio destacou os lotes 1 e 2 dos demais, em termos numéricos. Os testes de germinação e de primeira contagem da germinação também destacaram, em termos numéricos, o desempenho do lote 2 .

Na segunda época (Tabela 38), nenhum dos testes realizados separou os lotes estatisticamente. Os testes de germinação e primeira contagem da germinação apresentaram tendências semelhantes, ao apontar o lote 4 como tendo melhor desempenho. Os testes de envelhecimento acelerado e condutividade elétrica acusaram pequena variação entre os lotes, dificultando a observação de tendências para a classificação dos mesmos. $O$ teste de emergência das plântulas em campo apresentou valores altos, sendo que o menor valor foi $88 \%$ referente ao lote 5 .

O teste de lixiviação de potássio realizado nessa segunda época só mostrou diferenças estatísticas entre os lotes, quando foi realizado a $30^{\circ} \mathrm{C}$ de embebição (Tabela 30), destacando o lote 5 como de pior qualidade, embora não tenha se diferenciado dos lotes 3 e 4 . Os lotes 1 e 2 apresentam-se diferentes do lote 5 e se destacaram em termos de qualidade. Estes resultados condizem com a tendência apresentada pelo teste de 
emergência das plântulas em campo, que revelou, em valores numéricos, o pior desempenho do lote 5 , assim como foram compativeis com as tendências gerais observadas na primeira época, principalmente com os resultados de lixiviação de potássio realizado a $30^{\circ} \mathrm{C}$ e com o teste de condutividade elétrica. Estes resultados confirmam os obtidos por vários pesquisadores, entre eles MATTHEWS \& ROGERSON (1976), MARCOS FILHO (1979), MARCOS FILHO et al. (1982), MOSS \& MULLETT (1982), SREERAMULU (1983) e DIAS (1994) que ressaltaram o papel relevante da lixiviação de potássio para discriminar o potencial fisiológico de lotes de sementes.

Tabela 38. Média dos resultados de germinação (G), primeira contagem de germinação (PCG), envelhecimento acelerado (EA), condutividade elétrica (CE), emergência das plântulas em campo (EC) e umidade (U) para o cultivar IAC 15, durante a segunda época. Piracicaba, 1994.

\begin{tabular}{|c|c|c|c|c|c|c|}
\hline Lotes & $\begin{array}{l}\mathrm{G} \\
\%\end{array}$ & $\begin{array}{c}\text { PCG } \\
\%\end{array}$ & $\begin{array}{l}\text { EA } \\
\%\end{array}$ & $\begin{array}{c}\text { CE } \\
\text { umhos } / \mathrm{cm} / \mathrm{g}\end{array}$ & $\begin{array}{r}\mathrm{EC} \\
\%\end{array}$ & $\begin{array}{l}U \\
\%\end{array}$ \\
\hline 1 & $86 a^{l}$ & $74 a$ & $86 a$ & $87,44 a$ & $89 a$ & 9,3 \\
\hline 2 & $91 \mathrm{a}$ & $77 \mathrm{a}$ & $89 a$ & $86,11 \mathrm{a}$ & $85 a$ & 9,4 \\
\hline 3 & $87 a$ & $75 \mathrm{a}$ & $85 a$ & $92,21 \mathrm{a}$ & $92 a$ & 9,1 \\
\hline 4 & $95 a$ & $81 a$ & $87 a$ & $85,48 a$ & $91 a$ & 9,0 \\
\hline 5 & $89 a$ & $76 a$ & $90 a$ & $86,46 a$ & $88 a$ & 9,2 \\
\hline $\mathrm{CV}(\%)$ & 7,3 & 7,1 & 7,2 & 6,8 & 4,5 & - \\
\hline
\end{tabular}

${ }^{1}$ Médias seguidas por letras distintas diferem entre si ao nivel de $5 \%$ de significância. 
$\mathrm{Na}$ terceira época de testes (Tabela 39), o envelhecimento acelerado foi o único teste que apresentou diferenças estatísticas entre os lotes. $O$ lote 4 foi o que apresentou a maior média $(86 \%)$ e diferiu do lote $5(73 \%)$. Os demais lotes $(1,2$ e 3$)$ não se diferenciaram de nenhum dos lotes; porém, através dos valores numéricos, percebeu-se maior aproximação destes com o lote 4 que com o lote 5 , ou seja, tendência de serem lotes de melhor qualidade. MARCOS FILHO et al. (1984) e CALIARI \& MARCOS FILHO (1990) trabalhando respectivamente, com sementes de soja e ervilha, constataram a tendência deste teste em identificar lotes de qualidade elevada e agrupar os demais em niveis muito baixos. Por outro lado, KULIK \& YAKLICH (1982) destacaram a eficiência do envelhecimento em classificar corretamente os lotes de melhor qualidade e os piores. Os testes de condutividade elétrica e emergência das plântulas em campo concordaram com o teste de envelhecimento acelerado, por também mostrarem a tendência do lote 5 ser de qualidade inferior aos demais.

Os testes de germinação e primeira contagem da germinação não concordaram com os demais testes, pois ambos tenderam a apresentar os lotes 1 e 4 como inferiores aos demais, tendência esta não confirmada estatisticamente. 
Tabela 39. Média dos resultados de germinação (G), primeira contagem de germinação (PCG), envelhecimento acelerado (EA), condutividade elétrica (CE), emergência das plântulas em campo (EC) e umidade (U) para o cultivar IAC 15, durante a terceira época do experimento III. Piracicaba, 1994.

\begin{tabular}{lcccccc}
\hline Lotes & $\mathrm{G}$ & $\begin{array}{c}\mathrm{PCC} \\
\%\end{array}$ & $\begin{array}{c}\mathrm{EA} \\
\%\end{array}$ & $\begin{array}{c}\mathrm{CE} \\
\mu \mathrm{mhos} / \mathrm{cm} / \mathrm{g}\end{array}$ & $\begin{array}{c}\mathrm{EC} \\
\%\end{array}$ & $\begin{array}{c}\mathrm{U} \\
\%\end{array}$ \\
\hline & & & & & \\
\hline 1 & $85 \mathrm{a}^{1}$ & $82 \mathrm{a}$ & $82 \mathrm{ab}$ & $83,73 \mathrm{a}$ & $89 \mathrm{a}$ & 10,0 \\
2 & $89 \mathrm{a}$ & $85 \mathrm{a}$ & $84 \mathrm{ab}$ & $83,21 \mathrm{a}$ & $89 \mathrm{a}$ & 9,8 \\
3 & $91 \mathrm{a}$ & $85 \mathrm{a}$ & $85 \mathrm{ab}$ & $83,57 \mathrm{a}$ & $89 \mathrm{a}$ & 9,9 \\
4 & $86 \mathrm{a}$ & $80 \mathrm{a}$ & $86 \mathrm{a}$ & $89,97 \mathrm{a}$ & $88 \mathrm{a}$ & 10,0 \\
5 & $88 \mathrm{a}$ & $85 \mathrm{a}$ & $73 \mathrm{~b}$ & $92,79 \mathrm{a}$ & $82 \mathrm{a}$ & 10,0 \\
& & & & & & \\
\hline
\end{tabular}

${ }^{1}$ Médias seguidas por letras distintas diferem entre si ao nível de $5 \%$ de significância.

O teste de lixiviação de potássio mostrou diferenças estatísticas entre os lotes tanto a $25^{\circ} \mathrm{C}$ como a $30^{\circ} \mathrm{C}$ de embebição (Tabelas 28 e 31 , respectivamente). Quando foi realizado a $25^{\circ} \mathrm{C}$, houve interferência dos tratamentos na classificação dos lotes, sendo que os tratamentos $1(75 \mathrm{ml} / 30 \mathrm{~min}), 4(100 \mathrm{ml} / 30 \mathrm{~min})$ e $6(100 \mathrm{ml} / 90 \mathrm{~min})$ foram os que classificaram os lotes de maneira mais compatível com as tendências reveladas nas épocas anteriores, com os resultados obtidos a $30^{\circ} \mathrm{C}$ de embebição e com os outros testes de qualidade, pois destacaram o lote 1 como sendo diferente do lote 5 , sendo este o de pior qualidade. 
Os resultados dos testes de condutividade elétrica e emergência das plântulas em campo, em valores numéricos, concordaram com os resultados do teste de lixiviação de potássio ao indicar a inferioridade do lote 5. DIAS (1994) ressaltou que os resultados obtidos com soja, mostraram-se consistentes com as informações proporcionadas por outros testes de vigor, especialmente com a emergência das plântulas em campo. Outras pesquisas têm relacionado os resultados do teste de lixiviação de potássio ao de condutividade elétrica (SIMON \& RAJA-HARUN, 1972; PANDEY, 1989b; DONI FILHO, 1992; PRETE, 1992).

Os resultados do envelhecimento acelerado mostraram que o lote 5 diferiu do lote 4 , sendo de pior qualidade, enquanto os lotes 1,2 e 3 não diferiram de nenhum dos lotes; numericamente, porém, os lotes 1,2 e 3 se situaram mais próximos do lote 4 , demonstrando tendência de serem de alta qualidade. Estes resultados foram confirmados pelo teste de lixiviação de potássio realizado a $25^{\circ} \mathrm{C}$ (tratamentos 1,4 e 6 ). Os resultados do teste realizado a $30^{\circ} \mathrm{C}$ destacaram a superioridade do lote 1 em relação aos demais. Numericamente, no entanto, o lote 5 apresentou alto valor de lixiviação, o que vem a confirmar a inferioridade deste lote, como foi mostrado pelo envelhecimento acelerado.

O grau de umidade das sementes durante as três épocas variou de 9 a $10 \%$ entre os lotes; este fato é importante na execução dos testes, considerando-se que a uniformização da umidade das sementes é imprescindivel para a padronização das avaliações e obtenção de resultados consistentes (MATTHEWS, 1981; MARCOS FILHO et al., 1987 e LOEFFLER et al., 1988) 


\subsubsection{Considerações gerais}

O teste de lixiviação de potássio mostrou-se eficiente para separar os lotes em níveis de vigor, de maneira compatível com as respostas apresentadas pelos testes comumente utilizados para avaliação da qualidade físiológica, nas três épocas estudadas e para os dois cultivares. Quando a embebição foi feita a $30^{\circ} \mathrm{C}$, o teste se mostrou mais sensivel, fornecendo informações que só posteriormente foram reveladas por outros testes, principalmente para o cultivar IAC 15.

Os tratamentos, de maneira geral, não influenciaram a classificação dos lotes em níveis de vigor, sendo que, os tratamentos $1(75 \mathrm{ml} / 30 \mathrm{~min})$ e $4(100 \mathrm{ml} / 30$ $\min$ ) foram os que proporcionaram menores quantidades de potássio na água de embebição, sendo então, mais indicados por fornecerem informações mais rápidas (30 minutos) e de leituras mais precisas no fotômetro de chama.

Os lotes do cultivar BR 38 apresentaram maiores diferenças de qualidade fisiológica. Estas diferenças se acentuaram no decorrer das épocas, devido à ação do armazenamento; porém, a lixiviação de potássio, em ambas as temperaturas de embebição, foi capaz de detectá-las ainda na primeira época.

Os lotes do cultivar IAC 15 apresentaram menores diferenças de qualidade fisiológica; porém, a partir da segunda época, o teste de lixiviação de potássio realizado a $30^{\circ} \mathrm{C}$ de embebição, foi capaz de separá-los, enquanto que os outros testes foram menos sensiveis durante as três épocas, com exceção do teste de condutividade elétrica durante a primeira época e o teste de envelhecimento acelerado durante a terceira época. 


\section{CONCLUSÃO}

O teste de lixiviação de potássio pode se constituir em uma opção eficiente para avaliação da qualidade físiológica de sementes de soja, apresentando a sensibilidade necessária para a identificação de diferenças de vigor. Dentre as variações disponíveis na metodologia, a embebição das sementes em $75 \mathrm{ml}$ ou $100 \mathrm{ml}$ de água destilada, durante 30 minutos a $30^{\circ} \mathrm{C}$, proporciona respostas mais rápidas e leituras mais precisas no fotômetro de chama. 


\section{REFERÊNCIAS BIBLIOGRÁFICAS}

ABDEL SAMAD, IM. \& PEARCE, R.S. Leaching of ions, organic molecules and enzymes from seeds of peanut (A rachis hypogaea L.) imbibing without testas or with intact testas. J. Exp. Bot, Oxford, 29(113): 1471-78, 1978.

ABDUL-BAKI, A.A. Biochemical aspects of seed vigor. HortSci., Alexandria, 15(6): $765-71,1980$.

ABDUL-BAKI, A.A. \& ANDERSON, J.D. Viability and leaching of sugars from germinating barley. Crop. Sci., Madison, 10(1): 31-4, 1970.

ABDUL-BAKI, A.A. \& ANDERSON, J.D. Physiological and biochemical deterioration of seeds. In: KOZLOWSKI, T.T., ed. Seed Biology. New York, Academic Press, 1972, v.2. p.283-315.

ABDUL-BAKI, A.A. \& BAKER, J.E. Are changes in cellular organelles or membranes related to vigor loss in seeds? Seed Sci. and Technol., Zurich, 1(1): 89-125, 1973.

ALIZAGA, L.R.; MELLO, V.D.C.; SANTOS, D.S.B.D; IRIGON, D.L. Avaliação de testes de vigor em sementes de feijão e suas relações com a emergência a campo. Rev. Bras. de Sem., Brasília, 12(2): 44-58, 1990.

AMARAL, A.S. \& PESKE, S.T. pH do exsudato para estimar, em 30 minutos, a viabilidade de sementes de soja. Rev. Bras. de Sem., Brasilia, 6(3): 85-92, 1984. 
AMORIM, H.V. de. Aspectos bioquímicos e histoquímicos do grão do café verde relacionados com a deterioração da qualidade. Piracicaba, 1978. 85p (Livre-Docência, ESALQ/USP).

ANDERSON, J.D. Metabolic changes associated with senescence. Seed Sci. \& Technol., Zurich, 1(2): 401-16, 1973.

ASSOCIATION OF OFFICIAL SEED ANALYSTS. AOSA. Seed vigor testing handbook. East Lansing, AOSA, 1983. 88p.

BARROS, A.S do R. Testes para avaliação rápida da viabilidade e do vigor de sementes de soja (Glycine max (L) Merrill). Piracicaba, 1988. 140p. (Mestrado ESALQ/USP).

BARROS, A.S. do R. \& MARCOS FILHO, J. Testes para avaliação rápida da viabilidade de sementes de soja. Pesq. Agropec. Bras., Brasilia, 25(10): 1447-59, 1990.

BASAVARAJAPPA, B.S.; SHETTY, H.S.; PRAKASH, H.S. Membrane deterioration and other biochemical changes, associated with accelerated ageing of maize seeds. Seed Sci. \& Technol., Zurich, 19(2): 279-86, 1991.

BECWAR, M.R.; STANWOOD, P.C.; ROOS, E.E. Dehydration effects on imbibitional leakage from desiccation - sensitive seeds. Plant. Physiol., Rockville, 69(5): 1132-5, 1982.

BERJAK, P. \& VILLIERS, T.A. Ageing in plant embryos. II Age-induced damage and its repair during early germination. New Phytol., Cambridge, 71: 135-44, 1972a.

BERJAK, P. \& VILLIERS, T.A. Ageing in plant embryos. III. Acceleration of senescence following artificial ageing treatment. New Phytol., Cambridge, 71: 513-18, 1972b. 
BEWLEY, J.D. Membrane changes in seeds as related to germination and the perturbations resulting from deterioration in seed storage. In: McDONALD Jr., M.B. \& NELSON, C.J., ed. Physiology of the seed deterioration. CSSA, Madison, 1986. p.27-46.

BEWLEY, J.D. \& BLACK, M. Seeds: physiology of development and germination. New York, Plenum Press, 1985, 367p.

Branton, D. Membrane structure. An. Rev. Plant. Physiol., Palo Alto, 20: 209-38, 1969.

BRASIL, Ministério da Agricultura. Regras para análise de sementes. Brasília, 1992. $365 p$.

BROUWER, H.M. \& MULDER, J.C. Reduced steeping time for the conductivity vigor test of Phaseolus vulgaris L. seed. J. Seed Technol., Lansing, 7(1): 84-96, 1982.

BRUGGINK, H.; KRAAK, H.L.; DIJKEMA, M.H.G.E.; BEKENDAM, J. Some factors influencing electrolyte leakage from maize (Zea mays L.) kernels. Seed Sci. Res., Wallingford, 1(1): 15-20, 1991.

CALIARI, M.F. \& MARCOS FILHO, J. Comparação entre métodos para avaliação da qualidade fisiológica de sementes de ervilha (Pisum sativum L.). Rev. Bras. de Sem., Brasilia, 12(3): 52-75, 1990.

CARVALHO, N.M. de O conceito de vigor em sementes In: VIEIRA, R.D. \& CARVALHO, N.M. de. Testes de vigor em sementes. FUNEP, Jaboticabal, SP, 1994. p. 1-30.

CHAUHAN, K.P.S. The incidence of deterioration and its localization in aged seeds of soybeans and barley. Seed Sci. \& Technol., Zürich, 13(3): 769-73, 1985. 
CHING, T.M. Biochemical aspects of seed vigor. Seed Sci. \& Technol., Zürich, 1(1): $73-88,1973$.

COSTA, J.A. \& MARCHEZAN, E. Caracteństicas dos estádios de desenvolvimento da soja. Campinas, Fundação Cargill, 1982. 30p.

DELOUCHE, J. \& BASKIN, C.C. Accelerated aging techniques for predicting the relative storability of seed lots. Seed Sci. and Technol., Zürich, 1(1): 427-52, 1973.

De ROBERTIS, E.D.P. \& De ROBERTIS Jr., E.M.F. Bases da biologia celular e molecular. Rio de Janeiro, Ed. Guanabara, 1981. 332p.

DESWAL, D.P. \& SHEORAN, I.S. A simple method for seed leakage measurement: applicable to single seeds of any size. Seed Sci. \& Technol., Zürich, 21(1): 179-85, 1993.

DIAS, D.C.F. dos S. Testes de condutividade elétrica e de lixiviação de potássio para avaliação do vigor de sementes de soja (Glycine max (L.) Merill). Piracicaba, 1994 136p. (Doutorado - ESALQ/USP).

DONI FILHO, L. Efeitos do condicionamento fisiológico no comportamento de sementes de feijão (Phaseolus vulgaris L.). Piracicaba, 1992. 108p. (Doutorado ESALQ/USP).

DUKE, S.H.; KAKEFUDA, G.; HARVEY, T.M. Differential leakage of intracellular substances from imbibing soybean seeds. Plant. Physiol., Rockville, 72(4): 919-24, 1983.

FERRISS, R.S. \& BAKER, J.M. Relationships between soybean seed quality and performance in soil. Seed Sci. \& Technol., Zürich, 18(1): 51-73, 1990. 
FLOOD, R.G. \& SINCLAIR, A. Fatty acid analysis of aged permeable and impermeable seeds of Trifolium subterraneum (subterranean clover). Seed Sci. \& Technol., Zürich, 9(2): 475-7, 1981.

GILL, N.S. \& DELOUCHE, J.C. Deterioration of seed corn during storage. Proc. Assoc. of Off. Seed Anal., Lansing, 63(1): 33-50, 1973.

GIVELBERG, A.; HOROWITZ, M.; POLJAKOFF-MAYBER, A. Solute leakage from Solanum nignum L. seeds exposed to high temperatures during imbibition. J. Exp. Bot., Oxford, 35(161): 1754-63, 1984.

GORECKI, R.J.; HARMAN, G.E; MATTICK, L.R. The volatile exudates from germinating pea seeds of different viability and vigor. Can. J. Bot., Ottawa, 63(6): 1035-9, 1985.

GRANQVIST, G.A. Leakage of cations from a canot seed lot. Acta Hortc., The Hague, 215: 219-24, 1987.

HADAVIZADEH, A. \& GEORGE, R.A.T. The effect of mother plant nutrition on seed vigour as determined by the seed leachate conductivity in pea (Pisum sativum L.) cultivar "Sprite". Seed Sci. \& Techol., Zürich, 16(3): 589-99, 1988.

HALDER, S. \& GUPTA, K Effect of storage of sunflower seeds in hight and low relative humidity on solute leaching and internal biochemical changes. Seed Sci. \& Technol., Zürich, 8(3): 317-21, 1980.

HALLOIN, J.M. Solute loss from deteriorated cottonseed: relationship between deterioration, seed moisture, and solute loss. Crop. Sci., Madison, 15(1): 11-5, 1975.

HAMPTON, J.G. \& COOLBEAR, P. Potential versus actual seed performance - can vigour testing provide an answer? Seed Sci. \& Technol., Zürich, 18(2): 215-28, 1990. 
HARMAN, G.E. \& MATTICK, L.R. Association of lipid oxidation with seed ageing and death. Nature, London, 260(5549): 323-4, 1976.

HEPBURN, H.A.; POWELL, A.A.; MATTHEWS, S. Problems associated with the routine application of electrical conductivity measurements of individual seeds in the germination testing of peas and soybean. Seed Sci. \& Technol., Zurich, 12(2): 403-13, 1984.

HEPBURN, H.A.; GOODMAN, B.A.; McPHAIL, D.B.; MATTHEWS, S.; POWELL, A.A. An evaluation of EPR measurements of the organic free radical content of individual seeds in the non-destructive testing of seed viability. J. Exp. Bot, Oxford, 37(184): $1675-84,1986$.

KRZYZANOWSKI, F.C.; FRANÇA NETO, JB ; HENNING, A.A. Relato dos testes de vigor disponíveis para as grandes culturas. Inf. ABRATES, Londrina, 1(2): 15-37, 1991.

KRZYZANOWSKI, F.C. \& MIRANDA, Z.D.F.S. Relatório do comitê de vigor da ABRATES. Inf. ABRATES, Londrina, 1(1): 1-25, 1990.

KULIK, M.M. \& YAKLICH, R.W. Evaluation for vigor tests in soybean seeds relationship of accelerated aging, cold, sand bench and speed of germination tests to field performance. Crop Sci., Madison, 22(4): 766-70, 1982.

KUO, W.H.J. Delayed - permeability of soybean seeds: characteristics and screening methodology. Seed Sci. \& Technol., Zürich, 17(1): 131-42, 1989.

LARSON, L.A. The effect soaking pea seeds with or without seedcoats has on seedling growth. Plant Physiol., Rockville, 43(2): 255-9, 1968.

LEE, C.K. \& KARUNANITHY, R. Effects of germination on the chemical composition of Glycine and Phaseolus beans. I Sci. Food Agric., 51(4): 437-45, 1990. 
LIN, S.S. Alterações na lixiviação eletrolítica, germinação e vigor da semente de feijão envelhecida sob alta umidade relativa do ar e alta temperatura. Rev. Bras. de Fis. Veg., Brasilia, 2(2): 1-6, 1990

LOEFFLER, T.M.; TEKRONY, D.M.; EGLI, D.B. The bulk conductivity test as an indicator of soybean seed quality. J. Seed Technol., Lansing, 12(1): 37-53, 1988.

LOOMIS, E.L. \& SMITH, O.E. The effect of artificial ageing on the concentration of Ca, Mg, Mn, K, and $\mathrm{Cl}$ in imbibing cabbage seed. J Amer. Soc. Hort. Sci., S.Joseph, 105(5): $647-50,1980$

LOTT, J.N.A.; CAVDEK, V.; CARSON, J. Leakage of $\mathrm{K}, \mathrm{Mg}, \mathrm{Cl}, \mathrm{Ca}$ and $\mathrm{Mn}$ from imbibing seeds, grains and isolated seed parts. Seed Sci. Res., Wallingford, 1(1): 229 $33,1991$.

LUCCA FILHO, O.A. Metodologia dos testes de sanidade. In: SOAVE, J. \& WETZEL, M.M.V. da S. Patologia de sementes. Fundação Cargill. Campinas, SP, 1987. p.27698.

LUZZATI, V. \& HUSSON, F. The structure of the liquid - crystalline phases of lipid water systems. J. Cell. Biol., New York, 12(2): 207-20, 1962.

MADHUSUDANAN, K.N. \& JOHNSON, K.M. Solute leakage from Winged Bean (Psophocarpus tetragonolobus) seeds. Seed Sci. \& Technol., Zürich, 18(1): 157-62, 1990.

MARBACH, I. \& MAYER, A.M. The effect of temperature change on leakage from pea seeds. I Exp. Bot, Oxford, 36(164): 353-58, 1985.

MARCOS FILHO, J. Qualidade fisiológica e maturação de sementes de soja (Glycine max (L) Merill). Piracicaba, 1979.180p. (Livre-Docência-ESALQ/USP). 
MARCOS FILHO, J. Teste de envelhecimento acelerado. In: VIEIRA, R.D. \& CARVALHO, N.M. (ed.). Testes de vigor em sementes. Jaboticabal, FUNEP, 1994a. p.133-149.

MARCOS FILHO, J. Utilização de testes de vigor em programas de controle de qualidade de sementes. Inf. ABRATES, Londrina, 4(2): 33-5, $1994 b$.

MARCOS FILHO, J.; AMORIM, H.V.; SILVAROLA, M.B.; PESCARIN, H.M.C. Relação entre germinação, vigor e permeabilidade das membranas celulares durante a maturação de sementes de soja. In: SEMINÁRIO NACIONAL DE PESQUISA DE SOJA, 2., Brasília, 1981. Anais. Londrina, EMBRAPA/CNPSo, 1982. p.676-83.

MARCOS FILHO, J.; CARVALHO, R.V.; CÍCERO, S.M.; DEMÉTRIO, C.G.B. Qualidade físiológica e comportamento de sementes de soja no armazenamento e no campo. Anais. ESALQ, Piracicaba, 43: 389-43, 1986.

MARCOS FILHO, J.; CÍCERO, S.M.; SILVA, W.R. da. Avaliação da qualidade das sementes. Piracicaba, FEALQ, 1987. 230p.

MARCOS FILHO, J.; PESCARIN, H.M.C.; KOMATSU, Y.H.; DEMÉTRIO, C.G.B.; FANCELLI, A.L. Testes para avaliação do vigor de sementes de soja e suas relações com a emergência das plântulas em campo. Pesq. Agropec. Bras., Brasília, 19(5): $605-13,1984$.

MARCOS FILHO, J.; SILVA, W.R da; NOVEMBRE, A.D.C.; CHAMMA, H.M.C.P. Estudo comparativo de métodos para avaliação da qualidade fisiológica de sementes de soja, com ênfase ao teste de condutividade elétrica. Pesq. Agropec. Bras., Brasilia, 25(12): 1805-15, 1990

MATTHEWS, S. Evaluation of techniques for germination and vigour studies. Seed Sci. \& Technol., Zürich, 9(2): 543-51, 1981. 
MATTHEWS, S. Physiology of seed ageing. Out. Agnic., Great Britain, 14(2): 89-94, 1985.

MATTHEWS, S. \& CARVER, M.F.F. Further studies on rapid seed exudate tests indicative of potential field emergence. Proc. Int. Seed Test. Ass., Norway, 36(2): $307-12,1971$.

MATTHEWS, S. \& ROGERSON, N.E. The influence of embryo condition on the leaching of solutes from pea seeds. I Exp. Bot, Oxford, 27(100): 961-8, 1976.

McDONALD Jr., M.B. A review and evaluation of seed vigor testes. Proc. Assoc. of Off. Seed Anal, Lansing, 65: 109-39, 1975.

McKERSIE, B.D. \& STINSON, R.H. Effect of dehydration on leakage and membrane structure in Lotus comiculatus L. seeds. Plant. Physiol., Rockville, 66(1): 316-20, 1980.

MOSS, G.I. \& MULLETT, J.H. Potassium release and seed vigour in germinating (Phaseolus vulgaris L.) seed as influenced by temperature over the previous five generations. L Exp. Bot., Oxford, 33(137): 1147-60, 1982.

MULLETT, J.H. \& WILKINSON, R.I. The relationship between amounts of eletrolyte lost on leaching seeds of Pisum sativum and some parameters of plant growth. Seed Sci. \& Technol., Zürich, 7(3): 393-8, 1979.

MURPHY, J.B. \& NOLAND, T.L. Temperature effects on seed imbibition and leakage mediated by viscosity and membranes. Plant. Physiol., Rockville, 69(2): 428-31, 1982.

OHLROGGE, J.B. \& KERNAN, T.P. Oxygen-dependent aging of seeds. Plant. Physiol., Rockville, 70(3): 791-6, 1982. 
PANDEY, D.K. A rapid method for the prediction of germinability of French beans. Ann. Appl. Biol., Warwickshire, 113(2): 443-6, 1988a

PANDEY, D.K. Eletrolyte eflux into hot water as a test for predicting the germination and emergence of seeds. J. Hort. Sci., London, 63(4): 601-04, 1988b.

PANDEY, D.K. Priming induced alleviation of the effects of natural ageing derived selective leakage of constituents in French bean seeds. Seed Sci. \& Technol., Zürich, 17(2): 391-7, 1989a.

PANDEY, D.K. Ageing of French bean seeds at ambient temperature in relation to vigour and viability. Seed Sci. \& Technol., Zürich, 17(1): 41-7, 1989b.

PARRISH, D.J. \& LEOPOLD, A.C. Transient changes during soybean imbibition. Plant Physiol., Rockville, 59(6): 1111-5, 1977.

PARRISH, D.J. \& LEOPOLD, A.C. On the mechanism of aging in soybean seeds. Plant Physiol., Rockville, 61(3): 365-8, 1978.

PEARCE, R.S. \& ABDEL SAMAD, I.M. Change in fatty acid content of polar lipids during ageing of seeds of peanut (A rachis hypogaea L.). J. Exp. Bot., Oxford, 31(124): $1283-90,1980$.

PERRY, D.A. Report of the vigour test committee 1977-1980. Seed Sci. \& Technol., Zurich, 9(1): 115-26, 1981.

POWELL, A.A. Cell membranes and seed leachate conductivity in relation to the quality of seed for sowing. J. Seed Technol., Lansing, 10(2): 81-100, 1986.

POWELL, A.A. \& HARMAN, G.E. Absence of a consistent association of changes in membranal lipids with the ageing of pea seeds. Seed Sci. \& Technol., Zürich, 13(3): 659-67, 1985. 
POWELL, A.A. \& MATTHEWS, S. The damaging effect of water on dry pea embryos during imbibition. J. Exp. Bot., Oxford, 29(112): 1215-29, 1978

POWELL, A.A. \& MATTHEWS, S. The influence of testa condition on the imbibition and vigour of pea seeds. J. Exp. Bot., Oxford, 30(114): 193-7, 1979.

POWELL, A.A. \& MATTHEWS, S. Association of phospholipid changes with early stages of seed ageing. Ann. Bot., London, 47(5): 709-12, 1981.

POWELL, A.A.; OLIVEIRA, M.D.A.; MATTHEWS, S. The role of imbibition damage in determining the vigour of white and coloured seed lots of dwarf French beans (Phaseolus vulgaris). J. Exp. Bot., Oxford, 37(178): 716-22, 1986.

PRETE, C.E.C. Condutividade elétrica do exsudato de grãos de café (Coffea arabica L) e sua relação com a qualidade da bebida. Piracicaba, 1992. 125p. (Doutorado ESALQ/USP)

PRIESTLEY, D.A. \& LEOPOLD, A.C. Absence of lipid oxidation during accelerated aging of soybean seeds. Plant Physiol., Rockville, 63(4): 726-9, 1979.

PRIESTLEY, D.A. \& LEOPOLD, A.C. Lipid changes during natural aging of soybean seeds. Physiol. Plant., Copenhagen, 59: 467-70, 1983.

PRIESTLEY, D.A.; McBRIDE, M.B.; LEOPOLD, A.C. Tocopherol and organic free radical levels in soybean seeds during natural and accelerated aging. Plant Physiol., Rockville, 66(2): 715-9, 1980.

PRIESTLEY, D.A. WERNER, B.G.; LEOPOLD, A.C.; McBRIDE, M.B. Organic free radical levels in seeds and pollen: the effects of hydration and aging. Physiol. Plant, Copenhagen, 64(1): 88-94, 1985. 
QUEIROGA, V.P. \& PARRA, N.R. Análises dos eletrólitos nos exsudatos das sementes de girassol (Helianthus anuus L.). In: CONGRESSO BRASILEIRO DE SEMENTES, 6., Brasília, 1989. Resumos. Brasilia, ABRATES, 1989. 66p.

ROBERTS, E.H. Loss of seed viability: Chromosomal and genetical aspects. Seed Sci. \& Technol., Zürich, 1(3): 515-27, 1973.

ROBERTS, E.H. Physiology of ageing and its application to drying and storage. Seed Sci. \& Technol., Zürich, 9(2): 359-72, 1981.

RODELLA, A.A. \& BORGES, M.T.M. Manual básico para o laboratóno sucroalcooleiro. Piracicaba, 1989. 225p

SARRUGE, J.R. \& HAAG, H.P. Análises químicas em plantas. Piracicaba, ESALQ, 1974. $55 \mathrm{p}$.

SCHOETTLE, A.W. \& LEOPOLD, A.C. Solute leakage from artifially aged soybean seeds after imbibition. Crop Sci., Madison, 24(5): 835-8, 1984.

SHORT, G.E. \& LACY, M.L. Carbohydrate exudation from pea seeds: effect of cultivar, seed age, seed color, and temperature. Phytopathology, Lancaster, 66(2): 182-7, 1976.

SIDDIQUE, M.A. \& GOODWIN, P.B. Conductivity measurements on single seeds to predict the germinability of French beans. Seed Sci. \& Technol., Zürich, 13(3): $643-52,1985$.

SIMON, E.W. \& MATHAVAN, S. The time-course of leakage from imbibing seeds of different species. Seed Sci. \& Technol., Zürich, 14(1): 9-13, 1986.

SIMON, E.W. \& RAJA HARUN, R.M. Leakage during seed imbibition. J. Exp. Bot., Oxford, 23(77): 1076-85, 1972. 
SREERAMULU, $N$. Leakage during imbibition by seeds of bambana groundnut (Voandzeia subtermanea (L.) Thouars) at different stages of loss of viability. Trop. Agric., Trinidad, 60(4): 265-68, 1983.

STEWART, R.R.C. \& BEWLEY, J.D. Lipid peroxidation associated with accelerated aging of soybean axes. Plant. Physiol., Rockville, 65(2): 245-8, 1980.

STOECKENIUS, W. Some electron microscopical observations on liquid - crystalline phases in lipid - water systems. J Cell. Biol., New York, 12(2): 221-9, 1962.

SUBRAHMANYAM, P.; REDDY, M.N.; RAO, A.S. Exudation of certain organic compounds from seeds of groundnut. Seed Sci. \& Technol., Zürich, 11(2): 267-72, 1983.

SWAMY, P.M. \& NARASIMHA REDDY, S.B. Changes in the leakage of electrolytes from groundnut seeds (A rachis hypogaea) during after-ripening. Seed Sci. \& Technol., Zürich, 5(4): 645-8, 1977.

TAKAYANAGI, K. \& MURAKAMI, K. Rapid germinability test with exudates from seed. Nature, London, 218(4): 493-4, 1968.

TAKESHITA, H. \& KONNO, S. Application of Test-Tape method to examine viability of stored legume seeds. Japan Agrc. Res. Quart., 19(2): 151-2, 1985.

TEKRONY, D.M. Seed vigor testing - 1982. J. Seed Technol., Lansing, 8(1): 55-61, 1983.

TEKRONY, D.M. \& EGLI, D.B. Relationship between laboratory indices of soybean seed vigor and field emergence. Crop. Sci., Madison, 17(4): 573-7, 1977.

TRACY, W.F. \& JUVIK, J.A. Electrolyte leakage and seed quality on a shrunken-2 maize selected for improved field emergence. HortSci., Alexandria, 23(2): 391-2, 1988. 
VIEIRA, R.D. Testes de condutividade elétrica. In: VIEIRA, R.D. \& CARVALHO, N.M. de. Testes de vigor em sementes. FUNEP, Jaboticabal, SP, 1994. p.103-32.

VIEIRA, R.D; CARVALHO, N.M. de; SADER, R. Testes de vigor e suas possibilidades de uso. In: VIEIRA, R.D. \& CARVALHO, N.M de. Testes de vigor em sementes. FUNEP, Jaboticabal, SP, 1994. p.31-47.

VIEIRA, R.D.; TEKRONY, D.M.; EGLI, D.B. Effect of drought and defoliation stress in the field on soybean seed germination and vigor. Crop Sci., Madison, 32(2): 471-5, 1992.

YAKLICH, R.W. \& ABDUL-BAKI, A.A. Variabilty in metabolism of individual axes of soybean seeds and its relationship to vigor. Crop. Sci., Madison, 15(3): 424-6, 1975.

YAKLICH, R.W.; KULIK, M.M; ANDERSON, J.D. Evaluation of vigor test in soybean seeds: relationship of $\mathrm{ATP}$, conductivity, and radioactive tracer multiple criteria laboratory tests to field performance. Crop. Sci., Madison, 19(6): 806-10, 1979.

WANN, E.V. Leaching of metabolites during imbibition of sweet corn seed of different endosperm genotypes. Crop Sci., Madison, 26(4): 731-3, 1986.

WEGES, R. \& KARSSEN, C.M. The influence of redesiccation on dormancy and $\mathrm{K}^{+}$ leakage of primed lettuce seeds. Israel J of Bot., Jerusalém, 39(4-6): 327-36, 1990.

WILSON Jr,, D.O. \& McDONALD Jr,, M.B. The lipid peroxidation model of seed ageing. Seed Sci. \& Technol., Zürich, 14(2): 269-300, 1986.

WOOD, I.M. Response of seedlings of soybean, sunflower and sorghum to added mineral nutrients. Australian I. Exp. Agric., 30(6): 833-9, 1990.

WOODSTOCK, L.W. Physiological and biochemical tests for seed vigor. Seed Sci. \& Technol., Zürich, 1(1): 127-57, 1973. 
WOODSTOCK, L.W. Seed imbibition: a critical period for successfull germination. $\boldsymbol{J}$ Seed Technol., Lansing, 12(1): 1-15, 1988.

WOODSTOCK, L.W.; FURMAN, K.; LEFFLER, H.R. Relationship between weathering deterioration and germination, respiratory metabolism, and mineral leaching from cottonseeds. Crop. Sci., Madison, 25(3): 459-66, 1985.

ZONTA, E.P.; MACHADO, A.D.; SILVEIRA Jr., P. Sistemas de análise estatística para microcomputadores - SANEST. Pelotas, UFPel, 1984 (Registro SEI nº. 06606-0, Categoria $\mathrm{AO})$. 


\section{ANEXO}

\section{TESTE DE LIXIVIAÇÃo de POTÁSSIO}

\section{Obtenção dos padrões}

Inicialmente, parte-se de uma solução de 1000 ppm de K

$$
\begin{gathered}
\mathrm{C} \cdot \mathrm{V} \cdot=\mathrm{C}_{1} \cdot \mathrm{V}_{1} \text {, onde } \\
\mathrm{C}=\text { concentração da solução e } \mathrm{V}=\text { volume da solução. }
\end{gathered}
$$

Logo, para o preparo de $200 \mathrm{ml}$ de padrão, com 5 ppm de $\mathrm{K}$

$$
1000 \times \mathrm{V}=5 \times 200 \quad \text { e, portanto, } \mathrm{V}=1 \mathrm{ml}
$$

Assim, para preparar o padrão com $5 \mathrm{ppm}$ de $\mathrm{K}$, toma-se uma alíquota de $1 \mathrm{ml}$ da solução de $1000 \mathrm{ppm}$ de $\mathrm{K}$ e completa-se o volume para $200 \mathrm{ml}$.

Usando-se o mesmo procedimento devem-se obter padrões com 10, 15, 20, 25, 30, $35,40,45$ e $50 \mathrm{ppm}$ de $\mathrm{K}$.

\section{Obtenção das curvas de calibração}

Curva de calibração de $50 \mathrm{ppm} K$ e leitura 100: uma certa quantidade de água destilada é colocada em um recipiente e procede-se a leitura em fotômetro de chama, ajustando-a para zero.

Obs.: As "chaminhas" devem estar com coloração azul límpida e com formato perfeitamente cônico, para que a determinação seja precisa. 
Efetua-se, em seguida, a leitura da solução com 50 ppm de K, ajustando-a para 100. A seguir, as leituras dos padrões $45,40,35,30,20,15,10$ e 5 ppm K.

Com base nas leituras obtidas, calcula-se a regressão linear.

A regressão linear fornece uma equação $Y=a+b x$, onde:

$\mathrm{Y}=\mathrm{ppm} \mathrm{K} / \mathrm{ml}$

$\mathrm{a}=$ coeficiente angular.

$\mathrm{b}=$ ponto onde a curva intercepta o eixo $\mathrm{X} \rightarrow$ neste caso dá sempre zero, pois ajusta-se a leitura zero com o uso de água destilada.

$\mathrm{x}=$ leitura obtida em fotômetro de chama

$20 \mathrm{ppm} \mathrm{K} \rightarrow$ leitura 50

$30 \mathrm{ppm} \mathrm{K} \rightarrow$ leitura 50

$40 \mathrm{ppm} \mathrm{K} \rightarrow$ leitura 100

$\mathbf{5 0} \mathbf{p p m ~ K} \rightarrow$ leitura 100
Coeficiente 0,3949 (Figura 1 )

Coeficiente 0,5759 (Figura 2)

Coeficiente $\mathbf{0 , 3 6 8 3}$ (Figura 3)

Coeficiente 0,4551 (Figura 4)

\section{Cálculo da quantidade de $\mathrm{K}$ no teste de lixiviação}

Por exemplo, toma-se uma amostra, faz-se a leitura e o resultado é 69. O fotômetro tinha sido ajustado para $50 \mathrm{ppm} \mathrm{K}$ e leitura 100 , indicando que o coeficiente a ser usado é 0,4551 .

$$
\begin{aligned}
& \mathrm{Y}=0,4551 \mathrm{x}, \text { onde } \mathrm{x}=\text { leitura obtida e } \mathrm{Y}=\mathrm{ppm} \mathrm{K} / \mathrm{ml} \text { da amostra } \\
& \mathrm{Y}=0,4551 \times 69=31,40 \mathrm{ppm} \mathrm{K} / \mathrm{ml}
\end{aligned}
$$

Como no copo foram colocados $75 \mathrm{ml}$ de água para embebição e $1,54 \mathrm{~g}$ de sementes, calcula-se a quantidade de $\mathrm{K} / \mathrm{g}$ de sementes:

$31,40 \mathrm{ppm} \mathrm{K} / \mathrm{ml} \times 75 \mathrm{ml}=2355,14 \mathrm{ppm} \mathrm{K} / \mathrm{copo}$

Dividindo-se pelo peso das sementes,

$2355,14 \mathrm{ppm} \mathrm{K} /$ copo dividido por $3,54 \mathrm{~g}=665 \mathrm{ppm} \mathrm{K} / \mathrm{g}$ 